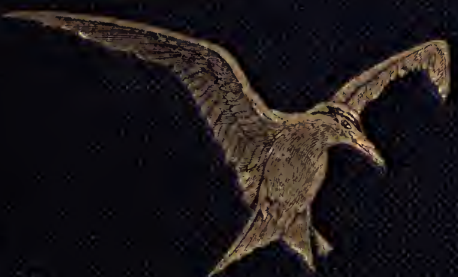


Southern Branch of the University of California Los Angeles

Form L-1

QL
676

F82y 
This book is DUE on the last date stamped below

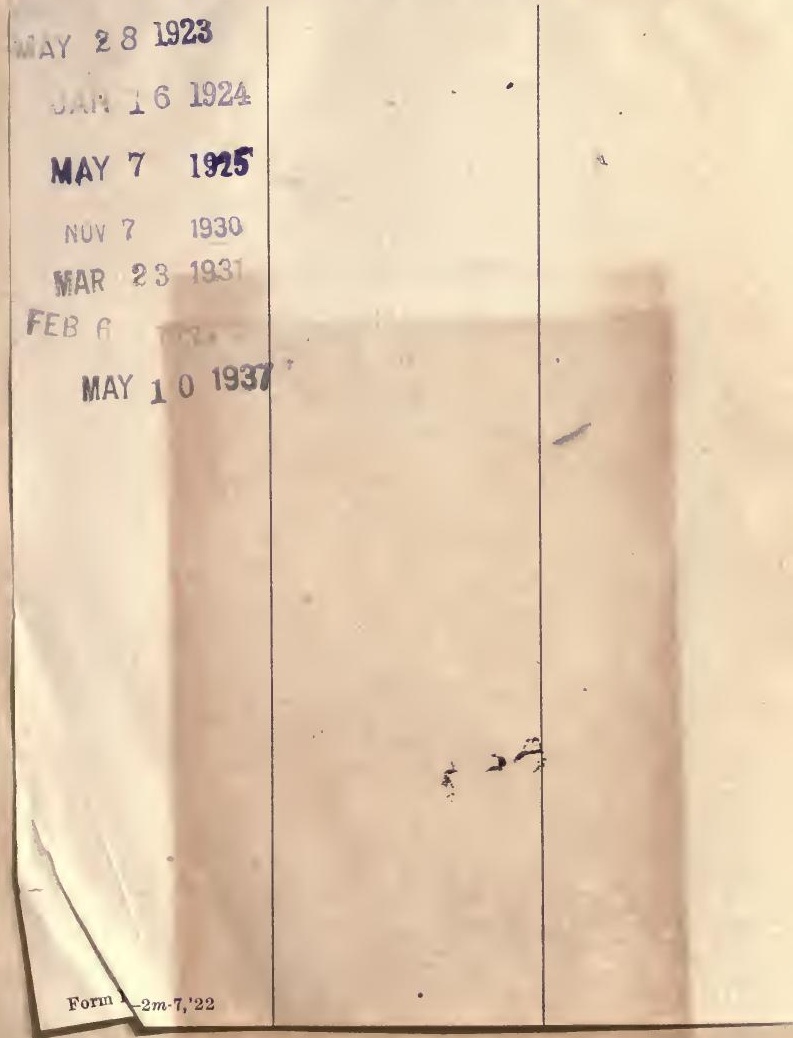


w. Warde to soles

Sincoln bolley

turay $r q \cdot$ iger

(at the requert of C.K. . B )

A YEAR WITH THE BIRDS 
s. 



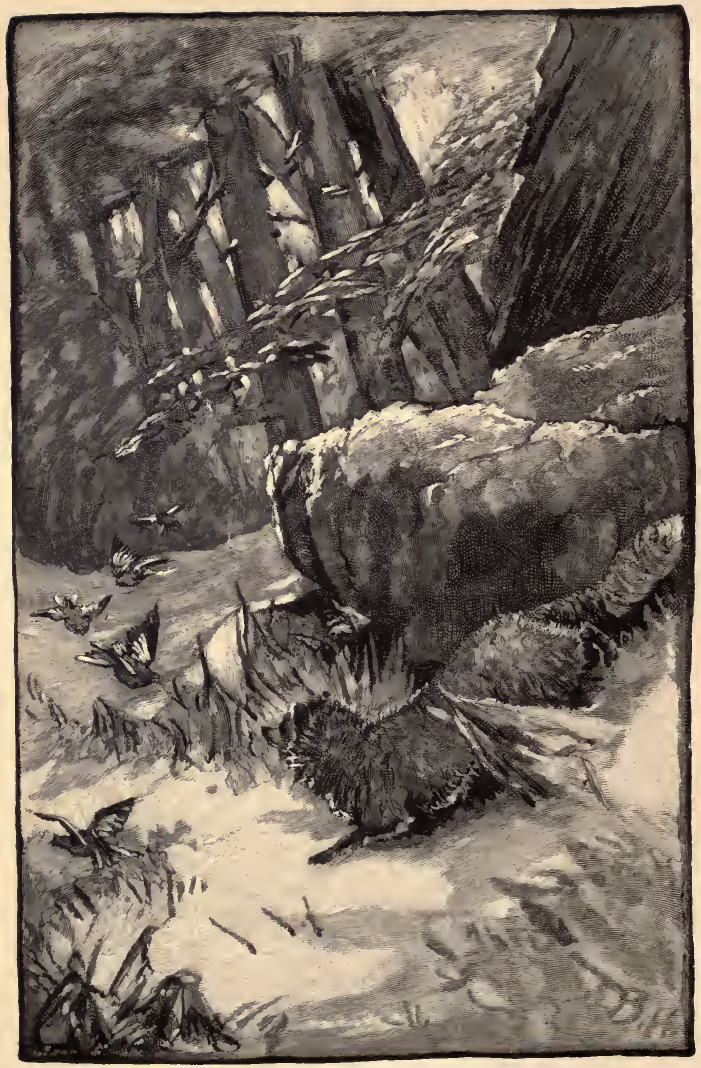

Fox and Snow-finches.-p. 100. 


\section{A YEAR}

\section{WITH THE BIRDS}

BY

W. WARDE FOWLER

AUTHOR OF "TALES OF THE BIRDS," ETC.

"L'uccello ha maggior copia di vita esteriore e interiore, che ncn hanno gli altri animali. Ora, se la vita è cosa più perfetta che il suo contrario, almeno nel:e creature viventi : e se perciò la maggior copia di vita è maggiore perfezione; anche per questo modo séguita che la natura degli uccelli sia più perfetta."-LEOPARDI : Elogio degli uccelli.

WITH ILLUSTRATIONS BY BRYAN HOOK

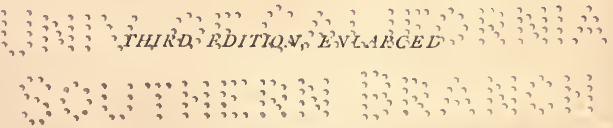

\section{3lonơon}

M A C I L L A N A N C O.

AND NEW YORK

I 89 I

39635 
Richard Clay and Sons, liulted, LONDON AND BUNGAY.

First two editions published elsezuhcre. Third edition, 1889; Reprinted, 1891.

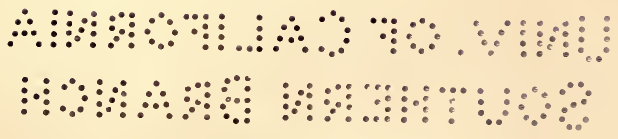




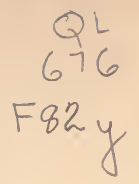

PATRI MEO

QVI CVM AVCVPIS NOMINE

AVIVM AMOREM

FILIO

TRADIDIT 



\section{PREFACE.}

THIS little book is nothing more than an attempt to help those who love birds, but know little about them, to realize something of the enjoyment which I have gained, in work-time as well as in holiday, for many years past, from the habit of watching and listening for my favourites.

What I have to tell, such as it is, is told in close relation to two or three localities : an English city, an English village, and a well-known district of the Alps. This novelty (if it be one) is not likely, I think, to cause the ordinary reader any difficulty. Oxford is so familiar to numbers of English people apart from its permanent residents, that I have ventured to write of it without stopping to describe its geography; and I have purposely confined myself to the city and its precincts, in order to show how rich in bird-life an English town may be. The Alps, too, are known to thousands, and the walk I have described in Chapter III., if the reader should be unacquainted with it, may easily be followed by reference to the excellent maps of the Oberland in the guide-books of Ball or Baedeker. The chapters 
about the midland village, which lies in ordinary English country, will explain their own geography.

One word about the title and the arrangement of the chapters. We Oxford tutors always reckon our year as beginning with the October term, and ending with the close of the Long Vacation. My chapters are arranged on this reckoning; to an Oxford residence from October to June, broken only by short vacations, succeeds a brief holiday in the Alps; then comes a sojourn in the midlands; and of the leisurely studies which the latter part of the Long Vacation allows, I have given an ornithological specimen in the last chapter.

Some parts of the first, second, and fifth chapters have appeared in the Oxford Magazine, and I have to thank the Editors for leave to reprint them. The third chapter, or rather the substance of it, was given as a lecture to the energetic Natural History Society of Marlborough College, and has already been printed in their reports; the sixth chapter has been developed out of a paper lately read before the Oxford Philological Society.

The reader will notice that I have said very little about uncommon birds, and have tried to keep to the habits, songs, and haunts of the commoner kinds, which their very abundance endears to their human friends. I have made no collection, and it will therefore be obvious to ornithologists that I have no scientific knowledge of structure and classification beyond that which I have obtained at second-hand. And, indeed, if I thought I 
were obtruding myself on the attention of ornithologists, I should feel as audacious as the Robin which is at this moment, in my neighbour's outhouse, sitting on eggs for which, with characteristic self-confidence, she has chosen a singular resting-place in an old cage, once the prisonhouse of an ill-starred Goldfinch.

There are few days, from March to July, when even the shortest stroll may not reveal something of interest to the careful watcher. It was pleasant, this brilliant spring morning, to find that a Redstart, perhaps the same incividual noticed on page $\mathrm{I} 2 \mathrm{O}$, had not forgotten my garden during his winter sojourn in the south; and that a pair of Pied Flycatchers, the first of their species which I have known to visit us here, were trying to make up their minds to build their nest in an old gray wall, almost within a stone's throw of our village church.

KINGHAM, OXON.

April 24, 1886. 


\section{NOTE TO SECOND EDITION.}

My little book, which never expected to spread the circle of its acquaintance much beyond its Oxford friends, has been introduced by the goodwill of reviewers to a wider society, and has been apparently welcomed there. To enable it to present itself in the world to better advantage, I have added to it a new chapter on the Alpine birds, and have made a considerable number of additions and corrections in the original chapters ; but I hope I have left it as modest and unpretending as I originally meant it to be.

During the process of revision, I have been aided by valuable criticisms and suggestions from several ornithological and bird-loving friends, and particularly from Rev. H. A. Macpherson, A. H. Macpherson, Esq., O. V. Aplin, Esq., and W. T. Arnold, Esq., whose initials will be found here and there in notes and appendices. I have also to thank Archdeacon Palmer for most kindly pointing out some blemishes in the chapter on the Birds of Virgil.

$$
\text { W. WARDE FOWI,ER. }
$$

LinColN COLLEGE, OXFord.

Nov. 19, 1886. 


\section{NOTE TO THIRD EDITION.}

THOUGH my knowledge of birds has naturally grown fast since I wrote these chapters, I have thought it better, except in one instance, to resist the temptation of re-writing or interpolating for this edition. The book stands almost exactly as it was when the second edition was issued; but the list of Oxford birds is omitted, as Mr. Aplin's work on the Birds of Oxfordshire, shortlyto be published by the Clarendon Press, will embody all the information there given. I regret that the frontispiece, drawn for the original edition by my friend Professor W. Baldwin Spencer, car no longer be reproduced.

I wish to express my thanks to Mr. B. H. Blackwell, of Oxford, not only for the care and pains he bestowed upon the issuc of the former editions, but for the ready courtesy with which he fell in with my wish to transfer the book to the hands of Messrs. Macmillan.

$$
\text { W. W. F. }
$$

June 4, 1889. 



\title{
CONTENTS.
}

\author{
CHAPTER I. \\ OXFORD: AUTUMN AND WINTER.
}

How I came to notice birds-Oxford favourable to bird-life -Late lingerers in October-Migration and pugnacity of Robins-The Bullfinch and the buds-Parsons' Pleasure and the Cherwell-Kingfishers rare in the summer termColouring of the Kingfisher-The Gray Wagtail at the weir ; its beauty-The Lesser Redpoll-An eccentric Jack-snipeBirds of the Park and Magdalen Walk-Lesser Spotted Woodpecker-Christchurch meadow and the Botanic Garden; Titmice, Blackbirds, Redwings-Sea-birds in Port Meadow ..................

CHAPTER II.

OXFORD: SPRING AND SUMMER.

Departure of winter birds-Warblers ; explanation of the term -Different kinds of warblers-Tree-warblers--Chiff-chaff's arrival-Willow-warbler's song and nest-Blackcap and Garden-warbler; their songs compared-The two Whitethroats at Parsons' Pleasure; how to distinguish themRiver-warblers; comparative rarity of Reed-warbler; his song compared with Sedge-warbler's-The Redstart and pollard willows-Summer habits of Oxford Sparrows-Flycatcher and other birds in the Parks ......... 


\section{CHAPTER III.}

The Alps in JUNE.

The Alpine pastures in June-Ornithologists and the Alps-

Johann Anderegg, a peasant naturalist-Number of species in Switzerland; abundance of food-Migration, complete and partial-The Alps how far a barrier to migrating birds-The three ornithological regions of Switzerland; migrations within them-Stanz-stadt and its reed-bed-Valley of the AaWhite Wagtail and Black Redstart-The Swallow familyThe Alps proper and their birds; Water-pipit, etc.-Citril Finch at the Engstlen Alp-Snow-finches-Rock-creeper; its habits-Birds of the pine-forests; Woodpeckers, Titmice-Crested Tit in the Gentelthal-Bonclli's Warbler at Meiringen

CHAPTER IV.

A Midland Village. Garden and Meadow.

Description of the vale of the Evenlode-Situation of the village; variety of scenery-Movements of the birds in the district-A bird-haunted garden-Redstart; its increase of late years-A Black Redstart on an ugly wall-Cuckoo and Robin's nest-Ingenious Nuthatches-Spotted Flycatcher ; his peculiarities-Allotments and Rooks-Green Sandpiper in the brook ; occurrence in midwinter-Habits of young birds -Rooks hostile to intruders-Long-tailed Tits on the ice .

CHAPTER V.

A Midland Village: Railway and Woodland.

Railways favourable to birds-Whinchat and Stonechat Peculiarities of the Buntings-Nests by the railway-Ring- 
ousel-Sing of the Tree-pipit-Pipits, Larks, WagtailsPredatory birds of the woods-Interview with a Grasshopper Warbler ; its "reel "-Beauty of the Nightingale ; its habits and song-Song-birds of the woods-Woodpeckers-Birds of the hills-Local migrations during the year . . . . . 144

CHAPTER VI.

The AlPs in SEPTEMBER.

Geography of Switzerland-Bird-catching on the passesBirds on the Brüing Pass-The Hasli-Thal-Crossbills-The Gadmen-Thal and Stein-alp-Migration on the Susten-pass - Hospenthal-Departure of Swallows-Migration of insects -Return to Meiringen-The Swiss peasant . . . . . .

\section{CHAPTER VII.}

THE BIRDS OF VIRGIL.

Virgil's haunts in Italy, in boyhood and manhood-Virgil true to nature-Pigeons in his poems-Crane and Stork; their migrations-Corvus and cornix-Swans-The ' alcyon,' in Latin and Greek ornithology-Voice of the KingfisherThe 'acalanthis'; warblers in Italy and Greece-Virgil's sea-birds and swallows - Nightingale in Homer and VirgilSimile of ghosts and birds in Sixth Aeneid-Autumn migrations from the north ........... 210

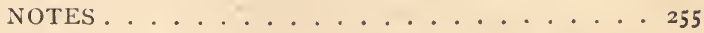

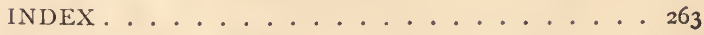




\section{LIST OF ILLUSTRATIONS.}

PAGE

Fox and Snow Finches ....... Frontispiece

First Lesson in Flying . . . . . . . . . . 20

Redpoles .................. . 22

Early Ablutions . . . . . . . . . . . . 28

The Tern, or Sea Swallow . . . . . . . . . . 34

Fieldfares . . . . . . . . . . . . 35

Reed Warbler .. . . . . . . . . . . to face 42

Nest on College Bell . . . . . . . . . . . 67

The Alps in June. . . . . . . . . Headpiece 68

Bonelli's Warbler. . . . . . . . . . . . . I 10

Kingham Rectory . . . . . . . . . . . . . . . I I I

Feat of a Nuthatch . . . . . . . . . . I29

Nest of Spotted Flycatcher ... . . . . . . . I3I

Rooks worrying Gulls . . . . . . . . . . . . . . 142

Whinchat on Telegraph Wires . . . . . . . . . 144

Grasshopper Warbler . . . . . . . . . . . . 155

Outdoor Relief . . . . . . . . . . . . . . 175

The Alps in September . . . . . . . . Headpiece 177

Crossbills . . . . . . . . . . to face 189

Johann Anderegg . . . . . . . . . . . . . . 209

Willow Warbler's Nest . . . . . . . . . . 254 


\section{A YEAR WITH THE BIRDS.}

\section{CHAPTER I.}

\section{OXFORD: AUTUMN AND WINTER.}

- For several years past I have contrived, even on the busiest or the rainiest Oxford mornings, to steal out for twenty minutes or half an hour soon after breakfast, and in the Broad Walk, the Botanic Garden, or the Parks, to let my senses exercise themselves on things outside me. This habit dates from the time when I was an ardent fisherman, and daily within reach of trout ; a long spell of work in the early morning used to be effectually counteracted by an endeavour to beguile a trout after breakfast.

By degrees, and owing to altered circumstances, 
the rod has given way to a field-glass, and the passion for killing has been displaced by a desire to see and know; a revolution which I consider has been beneficial, not only to the trout, but to myself. In the peaceful study of birds I have found an occupation which exactly falls in with the habit I had formed-for it is in the early morning that birds are most active and least disturbed by human beings; an occupation too which can be carried on at all times of the day in Oxford with much greater success than I could possibly have imagined when I began it. Even for one who has not often time or strength to take long rambles in the country round us, it is astonishing how much of the beauty, the habits, and the songs of birds may be learnt within the city itself, or in its immediate precincts.

The fact is, that for several obvious reasons, Oxford is almost a Paradise of birds. All the conditions of the neighbourhood, as it is now, are favourable to them. The three chief requisites of the life of most birds are food, water, and some kind of cover. For food, be they insect-eaters, or grub-eaters, they need never lack near Oxford. 
Our vast expanse of moist alluvial meadowunequalled at any other point in the Thames valley-is extraordinarily productive of grubs and flies, as it is of other things unpleasant to man. Any one can verify this for himself who will walk along the Isis on a warm summer evening, or watch the Sand-martins as he crosses the meadows to Hincksey. Snails too abound; no less than ninety-three species have been collected and recorded by a late pupil of mine. The ditches in all the water-meadows are teeming with fresh-water mollusks, and I have seen them dying by hundreds when left high and dry in a sultry season. Water of course is everywhere; the fact that our city was built at the confluence of Isis and Cherwell has had a good deal of influence on its bird-life. But after all, as far as the city itself is concerned, it is probably the conservative tranquillity and the comfortable cover of the gardens and parks that has chiefly attracted the birds. I fancy there is hardly a town in Europe of equal size where such favourable conditions are offered them, unless it be one of the old-fashioned well-timbered kind, such as Wiesbaden, Bath, or Dresden. The 
college system, which has had so much influence on Oxford in other ways, and the control exercised by the University over the government of the town, have had much to do with this, and the only adverse element even at the present day is the gradual but steady extension of building to the north, south, and west. A glance at a map of Oxford will show how large a space in the centre of the town is occupied by college gardens, all well-timbered and planted, and if to these are added Christchurch Meadow, Magdalen Park, the Botanic Garden, and the Parks, together with the adjoining fields, it will be seen that there must be abundant opportunity for observations, and some real reason for an attempt to record them.

Since the appearance in the Oxford Magazine, in May, I884, of a list of "The Birds of Oxford City," I have been so repeatedly questioned about birds that have been seen or heard, that it is evident there are plenty of possessors of eyes and ears, ready and able to make use of them. There are many families of children growing up in "the Parks" who may be glad to learn that life in a town such as Oxford is, does not exclude 


\section{A Paradise of Birds.}

them from some of the pleasures of the country. And I hold it to be an unquestioned fact, that the direction of children's attention to natural objects is one of the most valuable processes in education. When these children, or at least the boys among them, go away to their respective public schools, they will find themselves in the grip of a system of compulsory game-playing which will effectually prevent any attempt at patient observation. There is doubtless very much to be sa:d for this system, if it be applied, like a strong remedy, with real discriminating care; but the fact is beyond question, that it is doing a great deal to undermine and destroy some of the Englishman's most valuable habits and characteristics, and among others, his acuteness of observation, in which, in his natural state, he excels all other nationalities. It is all the more necessary that we should teach our children, before they leave home, some of the simplest and most obvious lessons of natural history.

So in the following pages it will be partly my object to write of the Oxford birds in such a way that any one of any age may be able to recognize 
some of the most interesting species that meet the eye or ear of a stroller within the precincts of the city. And with this object before me, it will be convenient, I think, to separate winter and summer, counting as winter the whole period from October to March, and as summer the warm season from our return to Oxford in April up to the heart of the Long Vacation; and we will begin with the beginning of the University year, by which plan we shall gain the advantage of having to deal with a few birds only to start with, and those obvious to the eye among leafless branches, thus clearing the way for more difficult observation of the summer migrants, which have to be detected among all the luxuriousness of our Oxford foliage.

I shall call the birds by their familiar English names, wherever it is possible to do so without danger of confounding species ; but for accuracy's sake, a list of all birds noticed in these pages, with their scientific names according to the best, or at any rate the latest, terminology, will be given in an appendix.

When we return to Oxford after our Long 


\section{Late Lingerers.}

Vacation, the only summer migrants that have not departed southwards are a few Swallows, to be seen along the banks of the river, and half-adozen lazy Martins that may cling for two or three weeks longer to their favourite nooks about the buildings of Merton and Magdalen. Last year (1884) none of these stayed to see November, so far as I could ascertain; but they were arrested on the south coast by a spell of real warm weather, where the genial sun was deluding the Robins and Sparrows into fancying the winter already past. In some years they may be seen on sunny days, even up to the end of the first week of November, hawking for flies about the meadow-front of Merton, probably the warmest spot in Oxford. White of Selborne saw one as late as the 2oth of November, on a very sunny warm morning, in one of the quadrangles of Christchurch ; it belonged, no doubt, to a late September brood, and had been unable to fly when the rest departed.

It is at first rather sad to find silence reigning in the thickets and reed-beds that were alive with songsters during the summer term. The 
familiar pollards and thorn-bushes, where the Willow-warblers and Whitethroats were every morning to be seen or heard, are like so many desolate College rooms in the heart of the Long Vacation. Deserted nests, black and mouldy, come to light as the leaves drop from the treesnurseries whose children have gone forth to try their fortune in distant countries. But we soon discover that things are not so bad as they seem. The silence is not quite unbroken : winter visitors arrive, and the novelty of their voices is cheering, even if they do not break into song; some kinds are here in greater numbers than in the hot weather, and others show themselves more boldly, emerging from leafy recesses in search of food and sunshine.

Every autumn brings us a considerable immigration of birds that have been absent during the summer, and increases the number of some species who reside with us in greater or less abundance all the year. Among these is the familiar Robin. My friend the Rev. H. A. Macpherson, in his recently published Birds of Cumberland, tells us that in that northern county the 
Robins slip quietly away southward in autumn. And it is in September and October that every town and village in the south of England is enlivened by their numbers and the pathetic beauty of their song; a song which I have observed as being of finer quality in England than on the continent, very possibly owing to a greater abundance of rich food. I have been even tempted to fancy that our English Robin is a finer and stouter bird than his continental relations. Certainly he is more numerous here at all times of the year, and he may travel where he pleases without fear of persecution; while the French and German Robins, who for the most part make for Italy in the autumn, return in spring in greatly diminished numbers, owing to the incurable passion of the Italians for "robins on toast."

It does not seem that they come to us in great numbers from foreign shores, as do many others of our common birds at this time of the year; but they move northwards and southwards within our island, presumably seeking always a moderately warm climate. At Parsons' Pleasure I have seen 
the bushes literally alive with them in October and November, in a state of extreme liveliness and pugnacity. This is the great season of their battles. Most country-people know of the warfare between the old and young Robins, and will generally tell you that the young ones kill their parents. The truth seems to be that after their autumnal moult, in the confidence of renewed strength, the old ones attack their offspring, and succeed in forcing them to seek new homes. This combativeness is of course accompanied by fresh vigour of song. Birds will sing, as I am pretty well convinced, under any kind of pleasant or exciting emotion-such as love, abundance of food, warmth, or anger ; and the outbreak of the Robin's song in autumn is to be ascribed, in part at least, to the last of these. Other reasons may be found, such as restored health after the moult, or the arrival in a warmer climate after immigration, or possibly even the delusion, already noticed, which not uncommonly possesses them in a warm autumn, that it is their duty to set about pairing and nest-building already. But all these would affect other species also, and the 
only reason which seems to suit the idiosyncrasies of the Robin is this curious rivalry between young and old.

The Robins, I need not say, are everywhere; but there are certain kinds of birds for which we must look out in particular places. I mentioned Parsons' Pleasure just now ; and we may take it very well as a starting-point, offering as it does, in a space of less than a hundred yards square, every kind of supply that a bird can possibly want ; water, sedge, reeds, meadows, gravel, railings, hedges, and trees and bushes of many kinds forming abundant cover. In this cover, as you walk along the footpath towards the weir, you will very likely see a pair of Bullfinches. They were here the greater part of last winter, and are occasionally seen even in college and private gardens; but very rarely in the breeding-season or the summer, when they are away in the densest woods, where their beautiful nest and eggs are not too often found. Should they be at their usual work of devouring buds, it is well worth while to stop and watch the process; at Parsons' Pleasure they can do no serious harm, and the 
Bullfinch's bill is not an instrument to be lightly passed over. It places him apart from all other common English birds, and brings him into the same sub-family as the Crossbill and the PineGrosbeak. It is short, wide, round, and parrot-like in having the upper mandible curved downwards over the lower one, and altogether admirably suited for snipping off and retaining those fat young juicy buds, from which, as some believe, the Bullfinch has come by his name. ${ }^{1}$

Parsons' Pleasure, i.e. the well-concealed bathing-place which goes by this name, stands at the narrow apex of a large island which is formed by the river Cherwell,-itself here running in two channels which enclose the walk known as Mesopotamia,--and the slow and often shallow stream by which Holywell mill is worked. The bird-lover will never cross the rustic bridge which brings him into the island over this latter stream, without casting a rapid glance to right and left. Here in the summer we used to listen to the

1 The nams is sometimes said to be a corruption of budfinch. But Prof. Skeat (Etym. Dict., s. v. Bull) compares it with bull-dog, the prefix in each case suggesting the stout build of the animal. 
Nightingale, or watch the Redstarts and Flycatchers in the willows, or feast our eyes with the splendid deep and glossy black-blue of the Swallow's back, as he darted up and down beneath the bridge in doubtful weather. And here of a winter morning you may see a pair of Moorfowl paddling out of the large patch of rushes that lies opposite the bathing-place on the side of the Parks ; here they breed in the summer, with only the little Reed-warblers as companions. And here there is always in winter at least a chance of seeing a Kingfisher. Why these beautiful birds are comparatively seldom to be seen in or about Oxford from March to July is a question not very easy to answer. The keeper of the bathing-place tells me that they go up to breed in ditches which run down to the Cherwell from the direction of Marston and Elsfield; and this is perhaps borne out by the discovery of a nest by a friend of mine, then incumbent of Woodeaton, in a deserted quarry between that village and Elsfield, fully a mile from the river. One would suppose, however, that the birds would be about the river, if only to supply their voracious 
young with food, unless we are to conclude that they feed them principally with slugs and such small-fry. Here is a point which needs investigation. The movements of the Kingfisher seem to be only partly understood, but that they do migrate, whether for short or long distances, I have no doubt whatever. ${ }^{1}$ On the Evenlode, another Oxfordshire river, which runs from Moreton-inthe-Marsh to join the Isis at Eynsham, they are rarely to be seen between March and September, or August at the earliest, while I seldom take a walk along the stream in the winter months without seeing one or more of them.

This bird is one of those which owe much to the Wild Birds Act, of which a short account will be found in Note $\mathrm{A}$, at the end of this volume. It may not be shot between March and August, and though it may be slaughtered in the winter with impunity, the gun-licence and its own rapid flight give it a fair chance of escape. Formerly it was a frequent victim:

By green Rother's reedy side

The blue Kingfisher flashed and died.

${ }^{1}$ See Mr. Seebohm's British Birds, vol. ii. p. 34.5 . 
Blue is the prevailing tint of the bird as he flies from you : it is seldom that you see him coming towards you; but should that happen, the tint that you chiefly notice is the rich chestnut of the throat and breast. One Sunday morning, as I was standing on the Cherwell bank just below the Botanic Garden, a Kingfisher, failing to see me, flew almost into my arms, shewing this chestnut hue; then suddenly wheeled, and flashed away all blue and green, towards Magdalen Bridge. I have seen a Kingfisher hovering like a dragon-fly or humming-bird over a little sapling almost underneath the bridge by which you enter Addison's Walk. Possibly it was about to strike a fish, but unluckily it saw me and vanished, piping shrilly. The sight was one of marvellous beauty, though it lasted but a few seconds.

One story is told about the Kingfisher, which I commend to those who study the varying effects of colours on the eye. Thompson, the famous Irish naturalist, was out shooting when snow was lying on the ground, and repeatedly saw a small brown bird in flight, which entirely puzzled him; at last he shot it, and found it to be a Kingfisher 
in its full natural plumage. ${ }^{1}$ Can it be that the swift flash of varying liquid colour, as the bird darts from its perch into the water, is specially calculated to escape the eye of the unsuspecting minnow? It nearly always frequents streams of clear water and rather gentle flow, where its intense brightness would surely discover it, even as it sits upon a stone or bough, if its hues as seen through a liquid medium did not lose their sheen. But I must leave these questions to the philosophers, and return to Parsons' Pleasure.

The island which I have mentioned is joined to Mesopotamia by another bridge just below the weir; and here is a second post of observation, with one feature that is absent at the upper bridge. There all is silent, unless a breeze is stirring the trees; here the water prattles gently as it slides down the green slope of the weir into the deep pool below. This motion of the water makes the weir and this part of the Cherwell a favourite spot of a very beautiful little bird, which

1 Mr. O. V. Aplin, of Banbury, tells me that he has heard it stated that if you shoot a Kingfisher, and it falls on the snow, you cannot see it. 


\section{The Gray Wagtail.}

haunts it throughout the October term. ${ }^{1}$ All the spring and early summer the Gray Wagtail was among the noisy becks and burns of the north, bringing up his young under some spray-splashed stone, or the moist arch of a bridge; in July he comes southwards, and from that time till December or January is constantly to be seen along Cherwell and Isis. $\mathrm{He}$ is content with sluggish water if he can find none that is rapid; but the sound of the falling water is as surely grateful to his ear as the tiny crustaceans he finds in it are to his palate. For some time last autumn (r 884) I saw him nearly every day, either on the stonework of the weir, or walking into its gentle waterslope, or running lightly over the islands of dead leaves in other parts of the Cherwell; sometimes one pair would be playing among the barges on the Isis, and another at Clasper's boat-house seemed quite unconcerned at the crowd of men and boats. It is always a pleasure to watch them; and though all Wagtails have their charm

${ }^{1}$ In 1885 Gray Wagtails were much less common in the south than in 1884 ; at the present time (Oct. 1886) they are again in their favourite places (see Frontispiece). 
for me, I give this one the first place, for its matchless delicacy of form, and the gentle grace of all its actions.

The Gray Wagtail is misnamed, both in English and Latin; as we might infer from the fact that in the one case it is named from the colour of its back, and in the other from that of its belly. ${ }^{1}$ It should be surely called the Long-tailed Wagtail, for its tail is nearly an inch longer than that of any other species; or the Brook-Wagtail, because it so rarely leaves the bed of the stream it haunts. All other Wagtails may be seen in meadows, ploughed fields, and uplands; but though I have repeatedly seen this one within the last year in England, Wales, Ireland, and Switzerland, I never but once saw it away from the water, and then it was for the moment upon a high road in Dorsetshire, and within a few yards of a brook and pool. Those who wish to identify it must remember its long tail and its love of water, and must also look out for the beautiful sulphur yellow of its under parts; in the spring both male and female have

I The scientific name is Motacilla sulphurea (in Dresser's List. M. melanope). 
a black chin and throat, like our common Pied Wagtail. No picture, and no stuffed specimen, can give the least idea of what the bird is like: the specimens in our Oxford Museum look "very sadly," as the villagers say; you must see the living bird in perpetual motion, the little feet running swiftly, the long tail ever gently flickering up and down. How can you successfully draw or stuff a bird whose most remarkable feature is never for a moment still?

While I am upon Wagtails, let me say a word for our old friend the common Pied Wagtail, who is with us in varying numbers all the year round. It is for several reasons a most interesting bird. We have known it from our childhood; but foreign bird-lovers coming to England would find it new to them, unless they chanced to come from Western France or Spain. Like one or two other species of which our island is the favourite home, it is much darker than its continental cousin the White Wagtail, when in full adult plumage. Young birds are indeed often quite a light gray, and in Magdalen cloisters and garden, where the young broods love to run and seek food on the 


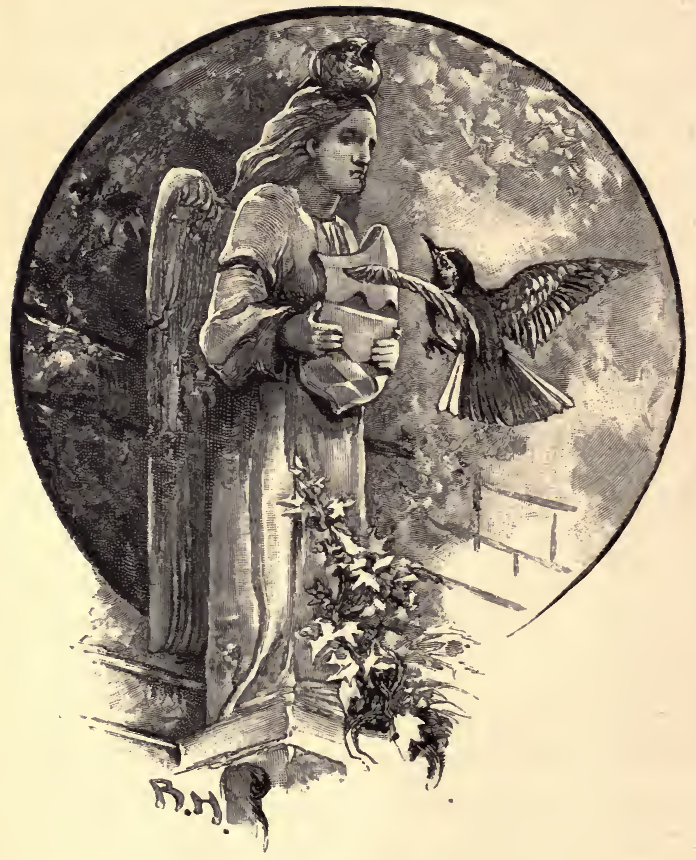

The mother flew repeatedly to the young one, hovered before it, chattered and encouraged it in every possible way. - p. $2 \mathrm{I}$. 


\section{Lesser Redpolls.}

beautifully-kept turf, almost every variety of youthful plumage may be seen in June or July, from the sombrest black to the brightest pearlgray. Last summer, I one day spent a long tire here watching the efforts of a parent to induce a young bird to leave its perch and join the others on the turf: the nest must have been placed somewhat high up among the creepers, and the young bird, on leaving it, had ventured no further than a little stone statue above my head. The mother flew repeatedly to the young one, hovered before it, chattered and encouraged it in every possible way; but it was a long time before she prevailed.

Let us now return towards the city, looking into the Parks on our way. The Curators of the Parks, not less generous to the birds than to mankind, have provided vast stores of food for the former, in the numbers of birches and conifers which flourish under their care. They, or their predecessors who stocked the plantations, seem to have had the particular object of attracting those delightful little north-country birds the Lesser Redpolls, for they have planted every kind of tree 
in whose seeds they find a winter subsistence.

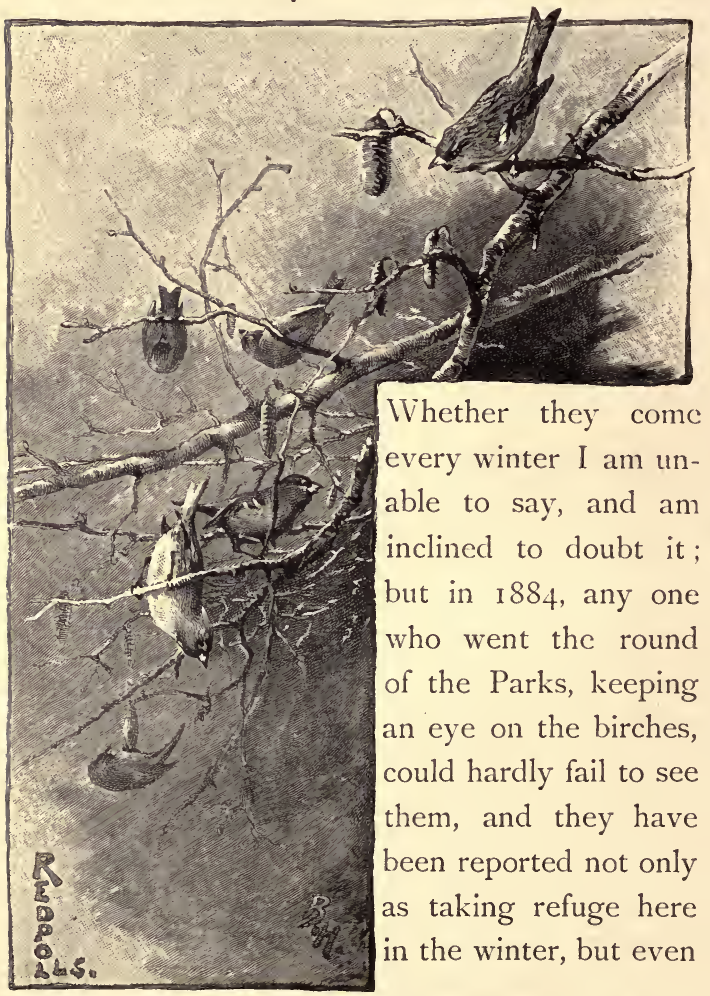

These tiny linnets at work in the delicate birch-boughs.-p. 23. 


\section{Lesser Redpolls.}

as nesting in the summer. A nest was taken from the branch of a fir-tree here in 1883 , and in this present year, if I am not mistaken, another nest was built. I failed to find it, but I several times saw a pair of sportive Redpolls at the southeast corner of the Parks. ${ }^{1}$

It is one of the prettiest sights that our whole calendar of bird-life affords, to watch these tiny linnets at work in the delicate birch-boughs. They fear no human being, and can be approached within a very few yards. They almost outdo the Titmice in the amazing variety of their postures. They prefer in a general way to be upside down, and decidedly object to the common-place attitudes of more solidly built birds. Otherwise they are not remarkable for beauty at this time of year; their splendid crimson crest-the "Bluttropf," as the Germans aptly call it-is hardly discernible, and the warm pink of their breasts has altogether vanished.

${ }^{1}$ At this same south-east corner, in May 1889 , I have several times found the trees above me alive with these bold little birds. I have also seen an egg taken from a nest in the Botanic Garden. We may now, I think, reckon these as residents both in summer and winter. 


\section{Oxford: Autumn and Winter.}

Before we leave the Parks I must record the fact that an eccentric Jack-snipe, who ought to have considered that he is properly a winter bird in these parts, was several times flushed here by the Cherwell in the summer of I884, and the natural inference would be that a pair had bred somewhere near. Col. Montagu, the most accurate of naturalists, asserted that it has never been known to remain and breed in England; yet the observer in this case, a well-known college tutor who knows a Jack-snipe when he sees it, has assured me positively that there was no mistake; and some well-authenticated cases seem to have occurred since Montagu wrote. ${ }^{1}$

There are plenty of common birds to be seen even in winter on most days in the Parks, such as the Skylark, the Yellow-hammer and its relative the Black-headed Bunting, the Pied Wagtail, the Hedge-sparrow, and others ; though lawn-tennis, and cricket, and new houses and brick walls, are slowly and surely driving them beyond the

1 A Jack-snipe picked up under the telegraph wires at Banbury in July, 1885 , was (Mr. Aplin tells me) in an emaciated condition; possibly an injured lird unable to migrate. 
Cherwell for food and shelter. But there are some birds which may be seen to greater advantage in another part of Oxford, and we will take the short line to Christchurch Meadow, past Holywell Church, doubtless the abode of Owls, and the fine elms of Magdalen Park, beloved by the Woodpigeons.

All this lower part of the Cherwell, from Holywell mill to its mouth at the barges, abounds in snug and secure retreats for the birds. In Addison's Walk, as well as in the trees in Christchurch Meadow, dwell the Nuthatch and the Tree-creeper, both remarkable birds in all their ways, and each representative of a family of which no other member has ever been found in these islands. They are tree-climbing birds, but they climb in very different ways : the Creeper helping himself, like the Woodpeckers, with the downward-bent feathers of his strong tail; while the Nuthatch, having no tail to speak of, relies chiefly on his hind claw. These birds are now placed, on account of the structure of their feet, in a totally different order to that of the Woodpeckers, who rank with the Swifts and the Nightjars. 
One is apt to think of the Creeper as a silent and very busy bird, who never finds leisure to rest and preen his feathers, or to relieve his mind with song. When he does sing he takes us a little aback. One spring morning, as I was strolling in the Broad Walk, a Creeper flew past me and fixed himself on the thick branch of an elm-not on a trunk, as usual-and uttered a loud and vigorous song, something after the manner of the Wren's. I had to turn the glass upon him to make sure that there was no mistake. This is the only occasion on which I have ever heard the Creeper sing, and it seems strange that a bird with so strong a voice should use it so seldom.

I have never but once seen the Green Woodpecker in Oxford, and that was as he flew rapidly over the Parks in the direction of the Magdalen elms. If he lives there, he must be known to the Magdalen men, but I have not had intelligence of him. The fact is that he is a much wilder bird than his near relation, the Lesser Spotted Woodpecker, who is, or was, beyond doubt an Oxford resident. A correspondent of the Oxford 
Magazine, "R. W. R.," states that this bird bred outside his window at Trinity a few years ago, "but has not done so lately for reasons of his own, of which I approve." Another correspondent, however, reports him from Addison's Walk; and Mr. Macpherson of Oriel, whose eye is not likely to have erred, believed that he saw one in the Broad IValk a few years ago. I myself have not seen the bird nearer Oxford than Kennington; but I am pretty sure that it is commoner and also less shy than is generally imagined, and also that the ornithologist who sees it is not likely to mistake it for another bird: its very small size-it is not so large as a sparrow-its crimson head, and its wings, with their black and white bars, making it a conspicuous object to a practised eye. ${ }^{1}$

Christchurch Meadow is a favourite home of the Titmice. I believe that I have seen all the five English species here within a space of a very few days : English, not British, for there is one other, the Crested Tit, of which I shall have more to say in another chapter. A family of Longtails,

${ }^{1}$ In May, r886, I saw one in a pollard willow at the northern edge of the Parks, near the new boathouse. 


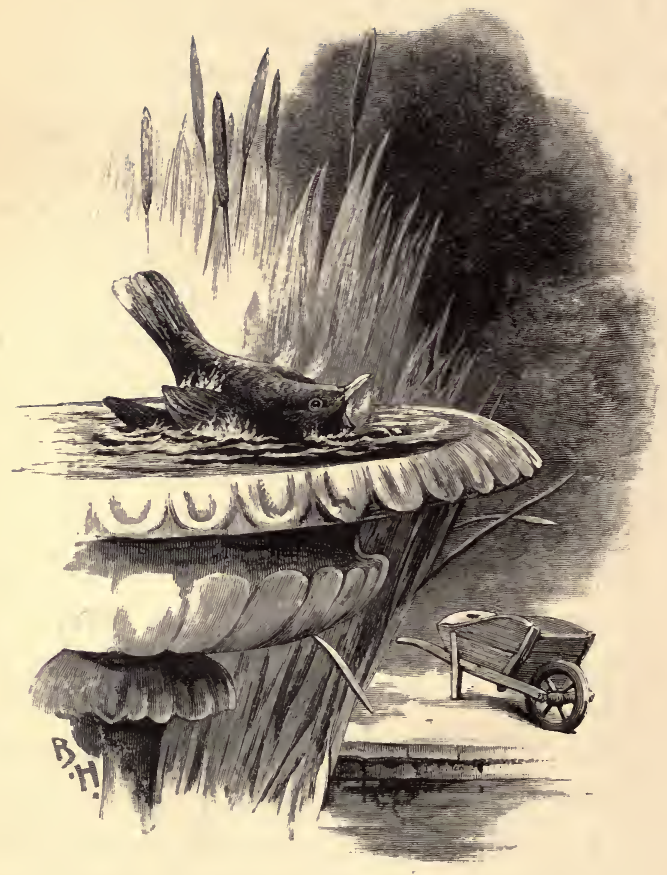

A blackbird proceeded calmly to take his bath in the fountain.-p. $3^{\circ}$. 
or Bottle-tits, flits from bush to bush, never associating with the others, and so justifying its scientific separation from them. Another family is to be seen in the Parks, where they build a nest every year. These delightful little birds are however quite willing to live in the very centre of a town, indifferent to noise and dust. A Marsh-tit was once seen performing its antics on a lamp-post in St. Giles. A Great-tit built its nest in the stump of an old laburnum, in the little garden of Lincoln College, within a few yards of the Turl and High Street; the nest was discovered by my dog, who was prowling about the garden with a view to cats. I took great interest in this brood, which was successfully reared, and on one occasion I watched the parents bringing food to their young for twenty minutes, during which time they were fed fourteen times. The ringing note of this Great-tit or his relations is the first to be heard in that garden in winter-time, and is always welcome. The little Blue-tit is also forthcoming there at times. One Sunday morning I saw a Blue-tit climbing the walls of my College quadrangle, almost after the manner 
of a Creeper, searching the crannies for insects, and even breaking down the crust of weathered stone. Among memories of the rain, mist, and hard work of many an Oxford winter spent among these gray walls, "haec olim meminisse juvabit."

But I have strayed away from Christchurch Meadow and the Botanic Garden. Here it is more especially that the Thrush tribe makes its presence felt throughout the autumn. In the Gardens the thrushes and blackbirds have become so tame from constant quiet and protection, that, like the donkeys at Athens of which Plato tells us, they will hardly deign to move out of your way. A blackbird proceeded calmly to take his bath, in the fountain at the lower end near the meadow, one morning when I was looking on, and seemed to be fully aware of the fact that there was a locked gate between us. Misselthrushes are also to be seen here; and all these birds go out of a morning to breakfast on a thickly-berried thorn-bush at the Cherwell end of the Broad Walk, where they meet with their relations the Redwings, and now and then with 
a Fieldfare. The walker round the meadow in winter will seldom fail to hear the harsh call of the redwing, as, together with starlings innumerable, and abundance of blackbirds, they utter loud sounds of disapproval. There is one bush here whose berries must have some strange ambrosial flavour that blackbirds dearly love. All the blackbirds in Oxford seem to have their free breakfast-table here, and they have grown so bold that they will return to it again and again as I teasingly walk up and down in front of it, merely flying to a neighbouring tree when I scrutinize them too closely in search of a lingering Ringousel. Who ever heard of a flock of blackbirds ? Here, however, in November, 1884 , was a sight to be seen, which might possibly throw some light on the process of developing gregarious habits. ${ }^{1}$

Rooks, Starlings, Jackdaws, and Sparrows, which abound here and everywhere else in

1 At Lulworth, in Dorset, when the berry-season begins, I have noticed that the blackbirds will congregate on the hedgerows in considerable numbers, and abandon for a time their skulking habits. This makes it often difficult to distinguish them at a distance from the Ring-ousels, which are there about the same time. 
Oxford, every one can observe for themselves, and of Sparrows I shall have something to say in the next chapter; but let me remind my young readers that every bird is worth noticing, whether it be the rarest or the commonest. My sister laughs at me, because the other day she found an old copy of White's Selborne belonging to me, wherein was inscribed on the page devoted to the Rook, in puerile handwriting, the following annotation: "Common about Bath" (where I was then at school). But I tell her that it was a strictly accurate scientific observation; and I only wish that I had followed it up with others equally unimpeachable.

But more out-of-the-way birds will sometimes come to Oxford, and I have seen a Kestrel trying to hover in a high wind over Christchurch Meadow, and a Heron sitting on the old gatepost in the middle of the field. Herons are often to be seen by the river-bank in Port Meadow; and it was here, some years ago, that Mr. W. T. Arnold, of University College, was witness of an extraordinary attack made by a party of three on some small birds. Port Meadow constantly en- 
tices sea-birds when it is under water, or when the water is receding and leaving that horrible slime which is so unpleasant to the nose of man; and in fact there is hardly a wader or a scratcher (to use Mr. Ruskin's term) ${ }^{1}$ that has not at one time or another been taken near Oxford. Sometimes they come on migration, sometimes they are driven by stress of weather. Two Stormy Petrels were caught at Bossom's barge in the Port Meadow not long ago, and exhibited in Mr. Darbey the birdstuffer's window. And a well-known Oxford physician has kindly given me an interesting account of his discovery of a Great Northern Diver, swimming disconsolately in a large hole in the ice near King's Weir, one day during the famous Crimean winter of $1854-5$; this splendid bird he shot with a gun borrowed from the inn at Godstow. During the spring and early summer of I866, our visitors from the seacoast were constant and numerous. Even the beautiful and graceful little Tern (Sterna Minuta)

1 I.e. for the Rasores, in Love's Meinie; where are some of the most delightfully wilful thoughts about birds ever yet published. 
more than once found his way here; and on the second occasion saved his own life by the confidence which he seemed to repose in man. 'I intended 'to shoot it,' wrote a young friend of mine, 'but relented when I saw how tame and trustful it was.'

Specimens of almost all such birds are to be seen in the bird-cases of the Museum, and occasionally they may be seen in the flesh in the Market. Both Market and Museum will give plenty to do on a rainy day in winter:-

Ubi jam breviorque dies et mollior aestas Quae vigilanda viris!

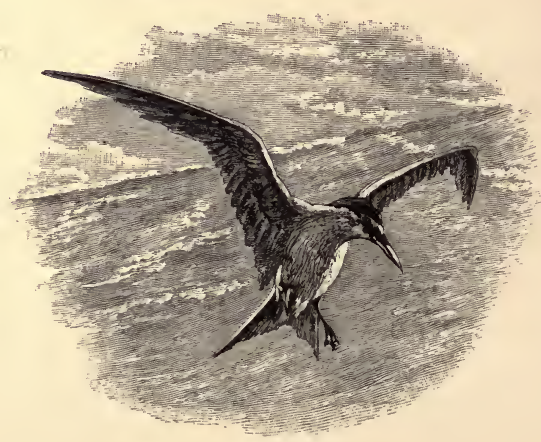




\section{CHAPTER II.}

OXFORD: SPRING AND EARLY SUMMER.

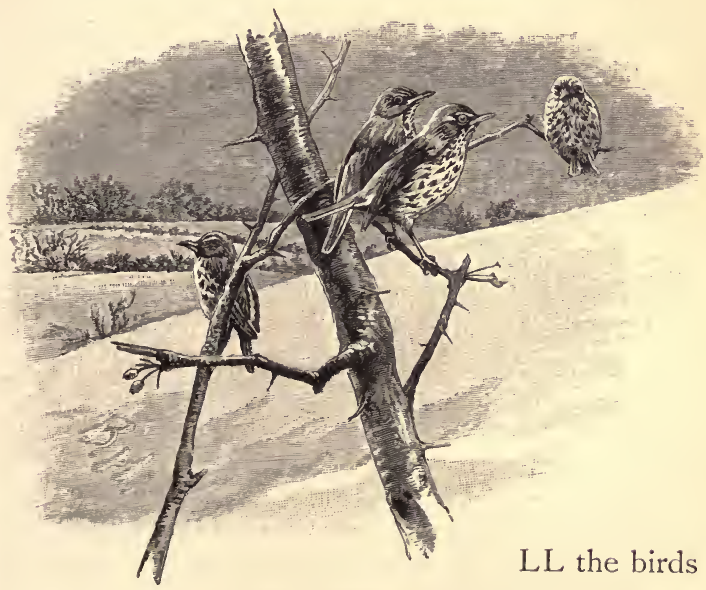

mentioned in the last chapter are residents in Oxford, in greater or less numbers according to the season, except the Fieldfares 


\section{Oxford: Spring and Early Summer.}

and Redwings, the Grey Wagtail, and the rarer visitors: and of these the Fieldfares and Redwings are the only true winter birds. They come from the north and east in September.and October, and depart again in March and April. When we begin our Summer Term not one is to be seen. The berries in the meadow are all eaten up long before Lent Term is over, and though these are not entirely or even chiefly the Redwing's food, the birds have generally disappeared with them.

They do not however leave the country districts till later. When wild birds like these come into a town, the cause is almost certain to be stress of weather; when the winter's back is broken, they return to the fields and hedges till the approach of summer calls them northwards. There they assemble together in immense flocks, showing all the restlessness and excitement of the smaller birds that leave us in the autumn; suddenly the whole mass rises and departs like a cloud. Accounts are always forthcoming of the departure of summer migrants, and especially of the Swallows and Martins, and there are few who 
have not seen these as they collect on the sunny side of the house-roof, or bead the parapet of the Radcliffe building, before they make up their minds to the journey. But few have seen the Fieldfares and Redwings under the same conditions, and I find no account of their migration, or at least of what actually happens when they go, in any book within my reach as I write. But on March I9, I884, I was lucky enough to see something of their farewell ceremonies. I was walking in some water-meadows adjoining a wood, on the outskirts of which were a number of tall elms and poplars, when I heard an extraordinary noise, loud, harsh, and continuous, and of great volume, proceeding from the direction of these trees, which were at the time nearly half-a-mile distant. I had been hearing the noise for a minute or two without attending to it, and was gradually developing a consciousness that some strange new agricultural instrument, or several of them, were at work somewhere near, when some Fieldfares flew past me to alight on the meadow not far off. Then putting up my glass, I saw that the trees were literally black with birds; and as long as 


\section{$3^{8}$ Oxford: Spring and Early Summer.}

I stayed, they continued there, only retreating a little as I approached, and sending foraging detachments into the meadow, or changing trees in continual fits of restlessness. The noise they made was like the deep organ-sounds of sea-birds in the breeding-time, but harsher and less serious. I would willingly have stayed to see them depart, but not knowing when that might be, I was obliged to go home: and the next day when I went to look for them, only a few were left.

These birds do not leave us as a rule before the first summer visitors have arrived. In the case I have just mentioned, the spring was a warm one, and the very next day I saw the everwelcome Chiff-chaff, which is the earliest to come and the latest to go, of all the delicate warblers which come to find a summer's shelter in our abundant trees and herbage.

I use this word 'warbler' "in a sense which calls for a word of explanation : for not only are the birds which are called in the natural history books by this name often very difficult to distinguish, but the word itself has been constantly used to denote a certain class of birds, without 
any precise explanation of the species meant to be included in it. Nor is it in itself a very exact word; some of the birds which are habitually called warblers do not warble in the proper sense of the word, ${ }^{1}$ and many others who really warble, such as the common Hedge-sparrow, have no near relationship to the class I am speaking of. But as it is a term in use, and a word that pleases, I will retain it in this chapter, with an explanation which may at the same time help some beginner in dealing with a difficult group of birds.

If the reader of this book who really cares to understand the differences of the bird-life which abounds around us, will buy for a shilling Mr. Dresser's most useful List of European Birds, ${ }^{2}$ he will find, under the great family of the Turdidae, three sub-families following each other on pages 7, 8, and 9, respectively called Sylvianae,

1 What this sense is may be guessed from Milton, Paradise Lost, Bk. v. 195-

- Fountains, and ye that warble as ye flow

Melodious murmurs, warbling tune his praise.'

The word seems to express a kind of singing which is soft, continuous, and 'legato.'

${ }^{2}$ Published by its author at 6 Tenterden Street, Hanover Square. 


\section{0 \\ Oxford: Spring and Early Summer.}

or birds of woodland habits, Phylloscopinae, or leaf-searching birds, and Acrocephalinae, or birds belonging to a group many of the members of which have the front of the head narrow and depressed: and under all these three sub-families he will find several species bearing in popular English the name of warbler. At the same time he will find other birds in these sub-families, which are quite familiar to him, but not as 'warblers' in any technical sense of the word; thus the Robin will be found in the first subfamily, and the Golden-crested Wren in the second. But, leavirig out these two species, and also the Nightingale, which is a bird of somewhat peculiar structure and habits, he will find four birds in the first sub-family belonging to the genus Sylvia, which are all loosely called warblers, and will be mentioned in this chapter as summer visitors to Oxford, viz. the Whitethroat (or Whitethroat-warbler), the Lesser Whitethroat, the Blackcap, and the Gardenwarbler; he will also find two in the second, belonging to the genus Phylloscopus, the Chiffchaff and the Willow-wren (or Willow-warbler), 


\section{Division of Warblers.}

and two in the third, belonging to the genus Acrocephalus, the Sedge-warbler and the Reedwarbler. Let it be observed that each of these three genera, Sylvia, Phylloscopus, and Acrocephalus, is the representative genus of the subfamily in this classification, and has given it its name; so that we might expect to find some decided differences of appearance or habit between the members of these genera respectively. And this is precisely what is the case, as any one may prove for himself by a day or two's careful observation.

The birds I have mentioned as belonging to the first genus, i. e. Whitethroat, etc., are all of a fairly substantial build, fond of perching, singing a varied and warbling song (with the exception of the Lesser Whitethroat, of whose song I shall speak presently), and all preferring to build their cup-shaped nest a little way from the ground, in a thick bush, hedge, or patch of thick-growing plants, such as nettles. They also have the peculiarity of loving small fruits and berries as food, and are all apt to come into our gardens in search of them, where they do quite 
as much good as harm by a large consumption of insects and caterpillars.

Secondly, the two kinds of birds belonging to the genus Phylloscopus, Chiff-chaff and Willowwarbler, are alike in having slender, delicate frames, with a slight bend forward as of creatures given to climbing up and down, in an almost entire absence of the steady perching habit, in building nests upon the ground with a hole at the side, and partly arched over by a roof of dried grass, in feeding almost exclusively on insects, and in singing a song which is always the same, each new effort being undistinguishable from the last. In fact these two birds are so much alike in every respect but their voices (which though unvarying are very different from each other), that it is almost impossible for a novice to distinguish them unless he hears them.

Thirdly, the two species belonging to the genus Acrocephalus, the Sedge- and Reed-warblers, differ from the other two groups in frequenting the banks of rivers and streams much more exclusively, where they climb up and down the water-plants, as their name suggests, and build 


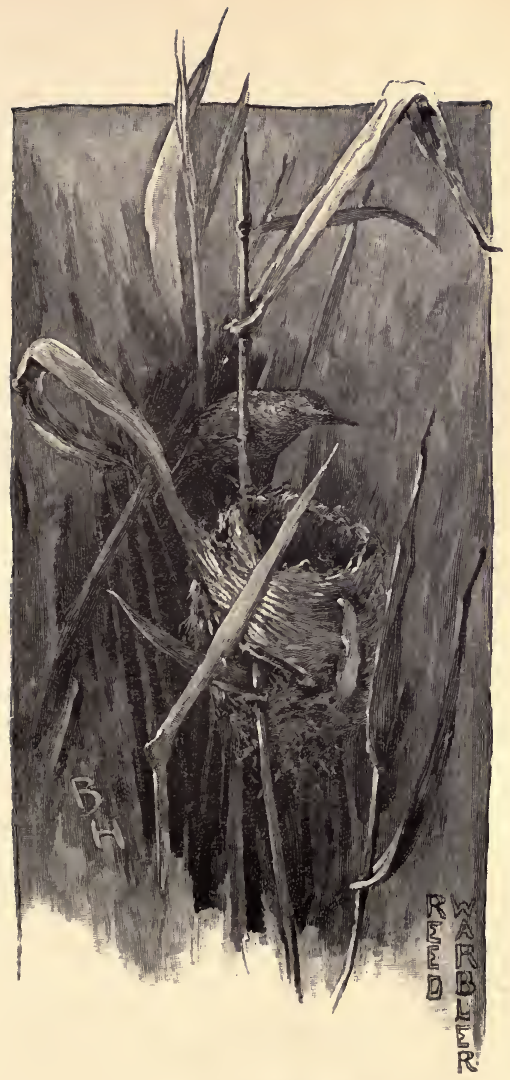

Reed Warbler. -p. 42. 

a cup-shaped nest; and also in the nervous intensity and continuity of their song.

These eight species, then, are the 'warblers,' of whom I am going to speak in the first place. They may easily be remembered in these three groups by any one who will take the trouble to learn their voices, and to look out for them when they first arrive, before the leaves have come out and the birds are shy of approach on account of their nests and young. But without some little pains confusion is sure to arise, as we may well understand when we consider that a century ago even such a naturalist as White of Selborne had great difficulty in distinguishing them; he was in fact the first to discover the Chiff-chaff (one of our commonest and most obvious summer migrants) as a species separate from the others of our second group. To give an idea of the progress Ornithology has made during the last century, I will quote Markwick's note on White's communication:- ' This bird, which Mr. White calls the smallest Willow-wren, or Chiff-chaff, makes its appearance very early in the spring, and is very common with us, but I cannot make 
44 Oxford: Spring and Early Summer.

out the three different species of Willow-wrens, which he says he has discovered.' ' Nothing but a personal acquaintance-a friendship, as I must call it in my own case-with these little birds, as they live their every-day life among us, will suffice to fix the individuality of each species in the mind; not even the best plates in a book, or the faded and lifeless figures in a museum. You may shoot and dissect them, and study them as you would study and label a set of fossils : but a bird is a living thing, and you will never really know him till you fully understand how he lives.

Let us imagine ourselves taking a stroll into the Parks with the object of seeing these eight birds, not as skeletons, but as living realities. The first to present themselves to eye and ear will be the two species of the second group, which may roughly be described (so far at least as England is concerned) as containing Treewarblers. From the tall trees in St. John's

1 The three species were the Wood-warbler, Phylloscopus sibilatrix (Bechst.), Willow-warbler, Ph. trochilus (Linn.), and Chiff-chaff, Ph. collybita (Viell.). Markwick declares that he could not distinguish the first of these from the other two. 
Gardens, before we reach the Museum, we are certain on any tolerably warm day to hear the Willow-warbler, which has been the last few years extremely abundant; in Oxford alone there must have been two or three hundred pairs in the spring of 1885 . From the same trees is also pretty sure to come ringing the two notes of the Chiff-chaff, which is a less abundant bird, but one that makes its presence more obvious. Let us pause here a moment to make our ideas clear about these two. We may justly take them first, as they are the earliest of their group to arrive in England.

When the first balmy breath of spring brings the celandines into bloom on the hedge-bank, and when the sweet violets and primroses are beginning to feel the warmth of the sun, you may always look out for the Chiff-chaff on the sheltered side of a wood or coppice. As a rule, I see them before I hear them; if they come with an east wind, they doubtless feel chilly for a day or two, or miss the plentiful supply of food which is absolutely necessary to a bird in full song. Thus in I 884, I noted March 20 as the first day on which 
46 Oxford: Spring and Early Summer.

I saw the Chiff-chaff, and March 23 as the first on which I heard him. The next year, the month of March being less genial, I looked and listened in vain till the 3 Ist. On that day I made a circuit round a wood to its sunny side, sheltered well from east and north, and entering for a little way one of these grassy 'rides' which are the delight of all wood-haunting birds, I stood quite still and listened. First a Robin, then a Chaffinch broke the silence; a Wood-pigeon broke away through the boughs; but no Chiff-chaff. After a while I was just turning away, when a very faint sound caught my ear, which I knew I had not heard for many months. I listened still more keenly, and caught it again; it was the prelude, the preliminary whisper, with which I have noticed that this bird, in common with a few others, is wont to work up his faculties to the effort of an outburst of song. In another minute that song was resounding through the wood.

No one who hails the approach of spring as the real beginning of a new life for men and plants and animals, can fail to be grateful to this little brown bird for putting on it the stamp and 
sanction of his clear resonant voice. We may grow tired of his two notes-he never gets beyond two-for he sings almost the whole summer through, and was in full voice on the $25^{\text {th }}$ of September in the same year in which he began on March 23rd; but not even the first twitter of the Swallow, or the earliest song of the Nightingale, has the same hopeful story to tell me as this delicate traveller who dares the east wind and the frost. They spend the greater part of the year with us; I have seen them still lurking in sheltered corners of the Dorsetshire coast, at the beginning of October, within sound of the seawaves in which many of them must doubtless perish before they reach their jonrney's end. And now and then they will even pass the winter with us: this was the case with one which took up his sojourn at Bodicote, near Banbury, in a winter of general mildness, though not unbroken, if I recollect right, by some very sharp frosts.

The Willow-warbler follows his cousin to England in a very few days, and remains his companion in the trees all through the summer. He has the same brownish-yellow back and yellowish- 
48 Oxford: Spring and Early' Summer.

white breast, but is a very little larger, and sings a very different song, which is unique among all British birds. Beginning with a high and tolerably full note, he drops it both in force and pitch in a cadence short and sweet, as though he were getting exhausted with the effort; for that it is a real effort to him and all his slim and tender relations, no one who watches as well as listens can have a reasonable doubt. This cadence is often perfect, by which I mean that it descends gradually, not of course on the notes of our musical scale, by which no birds in their natural state would deign to be fettered, but through fractions of one or perhaps two of our tones, and without returning upwards at the end; but still more often, and especially, as I fancy, after they have been here a few weeks, they take to finishing with a note nearly as high in pitch as that with which they began. ${ }^{1}$ This singular song is heard in summer term in every part of the Parks, and in the grass beneath the trees there

1 The song ceases about mid-June, and is not renewed till August : it is then usually so wanting in force as to be hardly recognizable. See Note B. at end of Volume. 
must be many nests; but these we are not likely to find except by accident, so beautifully are they concealed by their grassy roofs. Through the hole in the upper part of the side you see tiny eggs, speckled with reddish brown, lying on a warm bedding of soft feathers; one of these was built last May in the very middle of the lawn of the Parsonage-house at Ferry-Hincksey, and two others of exactly the same build, one a Chiffchaff's, were but a little way outside the gardengate, and had escaped the sharp eyes of the village boys when I last heard of them. Though from being on the ground they probably escape the notice of Magpies and Jackdaws and other egg-devouring birds, these eggs and the young that follow must often fall a prey to stoats and weasels, rats and hedgehogs. That such creatures are not entirely absent from the neighbourhood of the Parks, I can myself bear witness, having seen one morning two fine stoats in deadly combat for some object of prey which I could not discern, as I was divided from them by the river. The piping squeaks they uttered were so vehement and loud, that at the first moment I mistook them for 
the alarm-note of some bird that was strange to me. In July, I886, I saw a large stoat playing in Addison's Walk, when few human beings were about, and the young birds, newly-fledged, were no doubt an easy prey.

One word more before we leave the Treewarblers. In front of my drawing-room window in the country are always two rows of hedges of sweet peas, and another of edible peas; towards the end of the summer some little pale yellow birds come frequently and climb up and down the pea-sticks, apparently in search of insects rather than of the peas. These are the young Willowwarblers, which after their first moult assume this gently-toned yellow tint; and very graceful and beautiful creatures they are. I have sometimes seen them hover, like humming-birds, over a spray on which they could not get an easy footing, and give the stem or leaves a series of rapid pecks.

We have to walk but a little further on to hear or see at least two of our first group, the Sylviae, or fruit-eating warblers. As we pass into the Park by the entrance close to the house of the 
Keeper of the Museum, we are almost sure, on any sunny day, to hear both Blackcap and Garden-warbler, and with a little pains and patience, to see them both. These two (for a wonder) take their scientific names from the characteristics by which sensible English folk have thought best to name them; the Blackcap being Sylvia atracapilla, and the Garden-warbler Sylvia hortensis. Mr. Ruskin says, in that delicious fragment of his about birds, called Love's Meinie, that all birds should be named on this principle; and indeed if they had only to discharge the duty which many of our English names perform so well, viz. that of letting English people know of what bird we are talking, his plan would be an excellent one. Unluckily, Ornithology is a science, and a science which embraces all the birds in the world; and we must have some means of knowing for certain that we shall be understood of all the world when we mention a bird's name. This necessity is well illustrated in the case of the warblers. So many kinds of them are there, belonging to all our three groups, in Europe alone, not to speak of other parts of the 


\section{Oxford: Spring and Early Summer.}

world, that even a scientific terminology and description upon description have not been able to save the birds from getting mixed up together, or getting confounded with their own young, or with the young of other birds.

If the Blackcap were not a Sylvia, he could not well be scientifically named after his black head, for other birds, such as Titmice, have also black heads, and I have frequently heard the Cole Tit described as the Blackcap. In any case he should perhaps have been named after his wonderful faculty of song, in which he far excels all the other birds of our three groups. Most people know the Blackcap's song who have ever lived in the country, for you can hardly enter a wood in the summer without being struck by it ; and all I need do here is to distinguish it as well as I can from that of the Garden-warbler, which may easily be mistaken for it by an unpractised ear, when the birds are keeping out of sight in the foliage, as they often most provokingly will do. Both are essentially warblers; that is, they sing a strain of music, continuous and legato, instead of a song that is broken up into separate 
notes or short phrases, like that of the Songthrush, or the Chiff-chaff. But they differ in two points: the strain of the Blackcap is shorter, forming in fact one lengthened phrase "in sweetness long drawn out," while the Garden-warbler will go on almost continuously for many minutes together; and secondly, the Blackcap's music is played upon a mellower instrument. The most gifted Blackcaps-for birds of the same species differ considerably in their power of song-excel all other birds in the soft quality of their tone, just as a really good boy's voice, though less brilliant and resonant, excels all women's voices in softness and sweetness. So far as I have been able to observe, the Blackcap's voice is almost entirely wanting in that power of producing the harmonics of a note which gives a musical sound its brilliant quality; but this very want is what produces its unrivalled mellowness.

The other two members of our first group (we are still in genus Sylvia) are the two Whitethroats, greater and lesser, and we have not far to go to find them. They arrive just at the beginning of our Easter Term, but never come 


\section{Oxford: Spring and Early Summer.}

to Oxford in great numbers, because their proper homes, the hedge-rows, are naturally not common objects of a town. In the country the greater Whitethroats are swarming this year (1885), and in most years they are the most abundant of our eight warblers; and the smaller bird, less seen and less showy, makes his presence felt in almost every lane and meadow by the brilliancy of his note.

Where shall we find a hedge near at hand, where we may learn to distinguish the two birds? We left the Blackcaps and Garden-warblers at the upper end of the Park; we shall still have a chance of listening to them if we take the walk towards Parsons' Pleasure, and here in the thornhedge on the right hand of the path, we shall find both the Whitethroats. ${ }^{1}$ As we walk along, a rough grating sound, something like the noise of a diminutive corn-crake, is heard on the other side of the hedge-stopping when we stop, and

1 The spring of 1886 saw this helge deserted by both species ; the result of an outbreak of lawn-tennis in the adjoining field. They were lucky enough to find new quarters not far off. 
sounding ahead of us as we walk on. This is the teasing way of the greater Whitethroat, and it means that he is either building a nest in the hedge, or thinking of doing so. If you give him time, however, he will show himself, flirting up to the top of the hedge, crooning, craking, and popping into it again; then flying out a little way, cheerily singing a soft and truly warbling song, with fluttering wings and roughened feathers, and then perhaps perching on a twig to repeat it. Now you see the white of his throat; it is real white, and it does not go below the throat. In one book I have seen the Garden-warbler called a Whitethroat; but in his case the white is not so pure, and it is continued down the breast. The throat of both Whitethroats is real white, and they have a pleasant way of puffing it out, as if to assure one that there is no mistake about it.

But how to distinguish the two? for in size they differ hardly enough to guide an inexperienced eye. There are three points of marked difference. The larger bird has a rufous or rustycoloured back, ${ }^{1}$ and his wing-coverts are of much

1 The scientific name is appropriate, viz. Sylvia rufa. 
the same colour; while the back of the lesser bird is darkish or grayish brown. Secondly, the head of the lesser Whitethroat is of a much darker bluish-gray tint. But much the best point of distinction in the breeding season is in the song. As I have said, the larger bird warbles; but the lesser one, after a little preliminary soliloquy in an under-tone, bursts out into a succession of high notes, all of exactly the same pitch. It took me some time to find out who was the performer of this music which I heard so constantly in the hedges, for the bird is very restless and very modest. When I caught sight of him he would not stop to be examined closely. One day however he was kind enough to alight for a moment in a poplar close by me, and as I watched him in the loosely-leaved branches, he poured out the song, and duly got the credit for it.

We are now close to our old winter-station on the bridge over the mill-stream, and leaning over it once more on the upper side, we shall hear, if not see, both the remaining species of the warblers that Oxford has to show us. They are 
the only species of River-warblers that are known to visit England regularly every year; these two, the Sedge-warbler and the Reed-warbler, never fail, and the Sedge-warbler comes in very large numbers, but only a few specimens of other River-warblers have been found out in their venturesomeness. Still, every young bird-hunter should acquaint himself with the characteristics of the rarer visitors, in order to qualify himself for helping to throw light on what is still rather a dark corner of English ornithology. These same species which we so seldom see are swarming in the flat lands of Holland, close by us, and why should they not come over to the island which birds seem to love so dearly?

But there is no doubt that birds have ways, and reasons for them, which man is very unlikely ever to be able to understand. Why, as Mr. Harting asks, ${ }^{1}$ should the Reed-warbler be so much less "generally distributed" than the Sedge-warbler? That it is so, we can show well enough even from Oxford alone. You will find Sedge-warblers all along the Cherwell and the Isis, wherever there

1 Our Summer Migrants, p. 82. 
is a bit of cover, and very often they will turn up where least expected; in a corn-field, for example, where I have seen them running up and down the corn-stalks as if they were their native reeds. But you must either know where to find the Reed-warbler, or learn by slow degrees. Parsons' Pleasure is almost the only place known to me where

"The Reed-warbler swung in a nest with her young, Deep-sheltered and warm from the wind." 1

There is, however, in this case, at least a plausible answer to Mr. Harting's question. Owing to the prime necessity of reeds for the building of this deep-sheltered nest, which is swung between several of them, kept firm by their centrifugal tendency, yielding lovingly yet proudly to every blast of wind or current of water-owing to this necessity, the Reed-warbler declines to take up his abode in any place where the reeds are not thick enough and tall enough to give a real

1 Mr. Courthope's Paradise of Birds. No one who loves birds or poetry should fail to read Mr. Ruskin's commentary on the chorus from which these lines are taken, in Love's Meinie, p. 139 and foll. 
protection to himself and his brood. Now in the whole length of Isis between Kennington ${ }^{1}$ and Godstow, and of Cherwell between its mouth and Parsons' Pleasure, there is no reed-bed which answers all the requirements of this little bird. Now and then, it is true, they will leave the reeds for some other nesting-place; one of them sang away all the Summer Term of I 884 in the bushes behind the Museum, nearly half a mile from the river, and probably built a nest among the lilacbushes which there abound. But that year they seemed to be more abundant than usual; and this, perhaps, was one for whom there was no room in the limited space of the reeds at Parsons' Pleasure. Thick bushes, where many lithe saplings spring from a common root, would suit him better than a scanty reed-bed. ${ }^{2}$

1 Unless it be in the weste:nmost branch, which runs at the foot of the Berkshire hills. Near Godstow the nest is to be found, as Mr. W. T. Arnold, of University Col., has kindly informed me: for obvious reasons I will not describe the spot.

2 In the summer of 1886 this interesting bird was quite abundant in and round Oxford. If I am not mistaken a nest was built in the reeds of the fountain at the south end of the Botanic Garden, a perfectly secure spot. I heard the song there as late as the end of July. 
There is no great difficulty in distinguishing Sedge- and Reed-warblers, if you have an eye for the character of birds. The two are very different in temperament, though both are of the same quiet brown, with whitish breast. The Sedge-bird is a restless, noisy, impudent little creature, not at all modest or retiring, and much given to mocking the voices of other birds. This is done as a rule in the middle of one of his long and continuous outpourings of chatter; but I one day heard a much more ridiculous display of impertinence. I was standing at the bottom of the Parks, looking at a pair or two of Sedge-warblers on a bush, and wondering whether they were going to build a nest there, when a Blackbird emerged from the thicket behind me, and seeing a human being, set up that absurd cackle that we all know so well. Instantly, out of the bush I was looking at, there came an echo of this cackle, uttered by a small voice in such ludicrous tones of mockery, as fairly to upset my gravity. It seemed to say, "You awkward idiot of a bird, I can make that noise as well as you: only listen!"-

The Reed-warbler, on the other hand, is quieter 
and gentler, and utters, by way of song, a long crooning soliloquy, in accents not sweet, but much less harsh and declamatory than those of his cousin. I have listened to him for half-an-hour together among the bushes that border the reedbed, and have fancied that his warble suits well with the gentle flow of the water, and the low hum of the insects around me. He will sit for a long time singing on the same twig, while his partner is on her nest in the reeds below; but the Sedge-warbler, in this and other respects like a fidgety and ill-trained child, is never in one place, or in the same vein of song, for more than a minute at a time.

It is amusing to stand and listen to the two voices going on at the same time; the Sedge-bird rattling along in a state of the intensest excitement, pitching up his voice into a series of loud squeaks, and then dropping it into a long-drawn grating noise, like the winding-up of an oldfashioned watch, while the Reed-warbler, unaffected by all this volubility, takes his own line in a continued prattle of gentle content and selfsufficiency. 
These eight birds, then, are the warblers which at present visit Oxford. Longer walks and careful observation may no doubt bring us across at least two others, the Wood-warbler and the Grasshopper-warbler: the nest of the Wood-warbler has been found within three miles. Another bird, too, which is often called a warbler, has of late become very common both in and about Oxfordthe Redstart. Four or five years ago they were getting quite rare; but this year (I885) the flicker of the red tail is to be seen all along the Cherwell, in the Broad Walk, where they build in holes of the elms, in Port Meadow, where I have heard the gentle warbling song from the telegraph wires, and doubtless in most gardens. The Redstart is so extremely beautiful in summer, his song so tender and sweet, and all his ways so gentle and trustful, that if he were as common, and stayed with us all the year, he would certainly put our Robin's popularity to the proof. Nesting in our garden, or even on the very wall of our house, and making his presence there obvious by his brilliant colouring and his fearless domesticity, he might become, like his plainer cousin of the 
continent, the favourite of the peasant, who looks to his arrival in spring as the sign of a better time approaching. "I hardly hoped," writes my old Oberland guide to me, after an illness in the winter, "to see the flowers again, or hear the little Röthel (Black Redstart) under my eaves."

The Oxford Redstarts find convenient holes for their nests in the pollard willows which line the banks of the Cherwell and the many arms of the Isis. The same unvaried and unnatural form of tree, which looks so dreary and ghastly in the waste of winter flood, is full of comfort and adaptability for the bird in summer. The works of man, though not always beautiful, are almost always turned to account by the birds, and by many kinds preferred to the solitude of wilder haunts. Whether he builds houses, or constructs railways, or digs ditches, or forces trees into an unnatural shape, they are ready to take advantage of every chance he gives them. Only when the air is poisoned by smoke and drainage, and vegetation retreats before the approach of slums, do they leave their natural friends to live without the charm of their voices-all but that strange 
64 Oxford: Spring and Early Summer.

parasite of mankind, the Sparrow. He, growing sootier every year, and doing his useful dirty work with untiring diligence and appetite, lives on his noisy and quarrelsome life even in the very heart of London.

Whether the surroundings of the Oxford Sparrows have given them a sense of higher things, I cannot say; but they have ways 'which have suggested to me that the Sparrow must at some period of his existence have fallen from a higher state, of which some individuals have a Platonic $\alpha \nu \alpha \dot{\mu \nu} \sigma\lrcorner s$ which prompts them to purer walks of life. No sooner does the summer begin to bring out the flies among our pollard willows, than they become alive with Sparrows. There you may see them, as you repose on one of the comfortable seats on the brink of the Cherwell in the Parks, catching flies in the air with a vigour and address which in the course of a few hundred years might almost develop into elegance. Again and again I have had to turn my glass upon a bird to see if it could really be a Sparrow that was fluttering in the air over the water with an activity apparently meant to rival 
that of the little Fly-catcher, who sits on a bough at hand, and occasionally performs the same feat with native lightness and deftness. But these are for the most part young Sparrows of the year, who have been brought here perhaps by their parents to be out of the way of cats, and for the benefit of country air and an easily-digested insect diet. How long they stay here I do not know; but before our Autumn Term begins they must have migrated back to the city, for I seldom or never see them in the willows except in the Summer Term.

These seats by the Cherwell are excellent stations for observation. Swallows, Martins, and Sand-martins flit over the water; Swifts scream overhead towards evening; Greenfinches trill gently in the trees, or utter that curious lengthened sound which is something between the bleat of a lamb and the snore of a light sleeper; the. Yellow Wagtail, lately arrived, walks before you on the path, looking for materials for a nest near the water's edge ; the Fly-catcher, latest arrival of all, is perched in silence on the railing, darting now and then into the air for flies ; the Corn-crake sounds 
from his security beyond the Cherwell, and a solitary Nightingale, soon to be driven away by dogs and boats and bathers, may startle you with a burst of song from the neighbouring thicket.

Of the birds just mentioned, the Swifts, Swallows, and Martins build, I need hardly say, in human habitations, the Sand-martins in some sand- or gravel-pit, occasionally far away from the river. The largest colony of these little brown birds, so characteristic of our Oxford summer, is in a large sand-pit on Foxcombe Hill: there, last July, I chanced to see the fledgelings peeping out of their holes into the wide world, like children gazing from a nursery window. The destruction all these species cause among the flies which swarm round Oxford must be enormous. One day a Martin dropped a cargo of flies out of its mouth on to my hat, just as it was about to be distributed to the nestlings; a magnifying glass revealed a countless mass of tiny insects, some still alive and struggling. One little wasplike creature disengaged himself from the rest, and crawled down my hand, escaping literally from the very jaws of death. 


\section{A noisy Situation.}

Before I leave these birds of summer, let me record the fact that last June (1886) a pair of swallows built their nest on the circular spring of a bell just over a doorway behind the University Museum; the bell was constantly being rung, and the nest was not unfrequently examined, but they brought up their young successfully. This should be reassuring to those who believe that the Museum and its authorities are a terror to living animals.

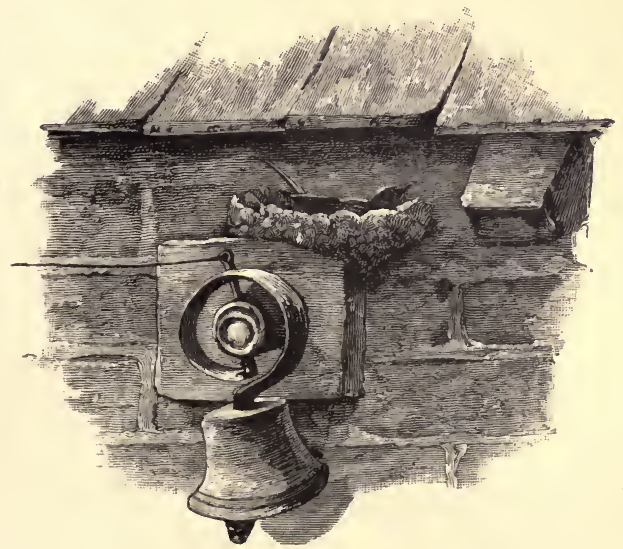

Nest on College Bell. 


\section{CHAPTER III.}

THE ALPS IN J U N E.
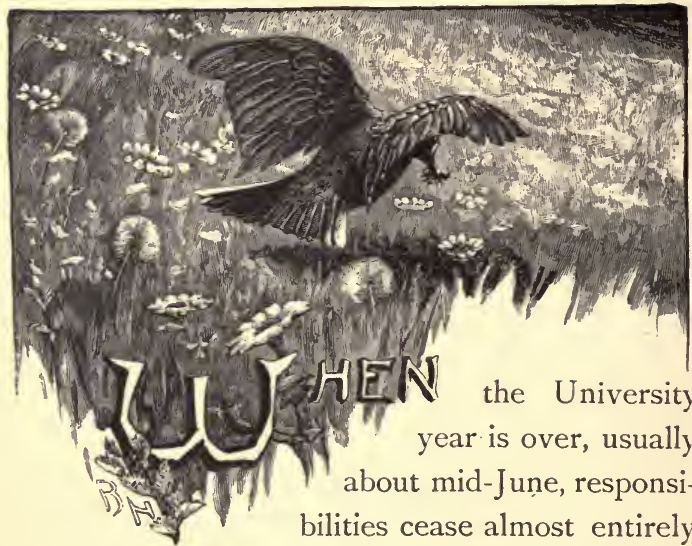

f퓨 the University year is over, usually about mid-June, responsibilities cease almost entirely for a few weeks; and it is sometimes possible to leave the lowlands of England and their familiar birds without delay, and to seek new hunting- 
grounds on the Continent before the freshness of early summer has faded, and before the world of tourists has begun to swarm into every picturesque hole and corner of Europe. An old-standing love for the Alpine region usually draws me there, sooner or later, wherever I may chance to turn my steps immediately after leaving England. He who has once seen the mountain pastures in June will find their spell too strong to be resisted.

At that early time the herdsmen have not yet reached the higher pastures, and cows and goats have not cropped away the flowers which scent the pure cool breeze. The birds are undisturbed and trustful, and still busy with their young. The excellent mountain-inns are comparatively empty, the Marmots whistle near at hand, and the snow lies often so deep upon footpaths where a few weeks later even the feeblest mountaineer would be at home, that a fox, a badger, or even a little troop of chamois, may occasionally be seen without much climbing. If bad weather assails us on the heights, which are liable even in June to sudden snow-storms and bitter cold, we can 
descend rapidly into the valleys, to find warmth and a new stratum of bird-life awaiting us. And if persistent wet or cold drives us for a day or two to one of the larger towns, Bern, or Zürich, or Geneva, we can spend many pleasant hours in the museums with which they are provided, studying specimens at leisure, and verifying or correcting the notes we have made in the mountains.

It is a singular fact that I do not remember to have ever seen an Englishman in these museums, nor have I met with one in my mountain walks who had a special interest in the birds of the Alps. Something is done in the way of butterflyhunting; botanists, or at least botanical tins, are not uncommon. The guide-books have something to say of the geology and the botany of the mountains, but little or nothing of their fauna. I have searched in vain through all the volumes of the Fahrbuch of the Swiss Alpine Club for a single article or paragraph on the birds, and the oracles of the English Alpine Club are no less dumb.

Not that ornithologists are entirely wanting for 
this tempting region; Switzerland has many, both amateur and scientific. A journal of Swiss ornithology is published periodically. Professor Fatio, of Geneva, one of the most distinguished of European naturalists, has given much time and pains to the birds of the Alpine world, and published many valuable papers on the subject, the results of which have been embodied in Mr. Dresser's Birds of Europe. But what with the all-engrossing passion for climbing, and the natural indisposition of the young Englishman to loiter in that exhilarating air, it has come to pass that the AngloSaxon race has for long past invaded and occupied these mountains for three months in each year, without discovering how remarkable the region is in the movements and characteristics of its animal life.

I myself have been fortunate in having as a companion an old friend, a native of the Oberland, who has all his life been attentive to the plants and animals of his beloved mountains. Johann Anderegg will be frequently mentioned in this chapter, and I will at once explain who he is. A peasant of the lower Hasli-thal, in the canton of Bern, born before the present excellent system of 
education had penetrated into the mountains, was not likely to have much chance of developing his native intelligence; but I have never yet found his equal among the younger generation of guides, either in variety of knowledge, or in brightness of mental faculty. He taught himself to read and write, and picked up knowledge wherever he found a chance. When his term of military service was over, he took to the congenial life of a guide and "jäger," in close fellowship with his first cousin and namesake, the famous Melchior, the prince of guides. But a long illness, which sent him for many months to the waters of Leukerbad, incapacitated him for severe climbing, and at the same time gave him leisure for thinking and observing: Melchior outstripped him as a guide, and their companionship, always congenial to both as men possessed of lively minds as well as muscular bodies, has long been limited to an occasional chat over a pipe in winter-time.

But he remained an ardent hunter, and has always been an excellent shot: and it was in this capacity, I believe, that he first became useful to the Professor Fatio whom I mentioned just now. 
He did much collecting for him, and in the course of their expeditions together, contrived to learn a great deal about plants, insects, and birds, most of which he retains in his old age. There is nothing scientific in his knowledge, unless it be a smattering of Latin names, which he brings out with great relish if with some inaccuracy; but it is of a very useful kind, and is aided by a power of eyesight which is even now astonishing in its keenness. I first made his acquaintance in 1868 , and for several years he accompanied my brother and myself in glacier-expeditions in all parts of the Alps; but it has been of late years, since we have been less inclined for strenuous exertion, that I have found his knowledge of natural history more especially useful to me. He is now between sixty and seventy, but on a bracing alp, with a gun on his shoulder, his step is as firm and his enjoyment as intense, as on the day when he took us for our first walk on a glacier, eighteen years ago.

The mention of his gun reminds me, that though my old friend's eyes and my own fieldglasses were of the greatest help to me, I could 
not always satisfy myself as to the identity of a species; and two years ago I was forced to sacrifice the lives of some six or seven individuals. This, it is worth knowing, is illegal in all parts of Switzerland, and illegal at all times of the year; and I had to obtain a license from the Cantonal Government at Bern, kindly procured for me by another old acquaintance, Herr Immer of Meiringen and the Engstlen-alp, to shoot birds 'in the cause of science.' This delighted Anderegg ; but at my earnest request he suppressed his sporting instincts, or only gave them rein in fruitless scrambles over rock and snow in search of Ptarmigan and Marmots.

I propose to occupy the latter part of this chapter in taking my readers a short expedition, in company with Anderegg, in search of Alpine birds; but let me first say something of the general conditions and characteristics of bird-life in Switzerland.

And first of the number of species, and abundance of individuals. People sometimes tell me that they never see any birds in the Alps. An elderly German, whose bodily exertions were 
limited, and whose faculties seemed to turn inwards on himself instead of radiating outwards, could not understand why I should go to Switzerland to study birds-for he could see none. And it is indeed true that they do not swarm there, as with us ; in this respect Switzerland is like the rest of the Continent. It is a curious fact, that though we have only lately begun to preserve our small birds by law in the breeding-season, they are far more abundant here than they are in any part of the Continent known to me: and this is the case even with the little delicate migrants, many of which seem to have a preference for England in spite of the risk of the sea-crossing. I remember taking up a position one afternoon by the side of a rushing stream, dividing beautiful hay-meadows, and edged with dwarf willows; and during the half-hour I sat there, I neither saw nor heard a single bird. In such a spot in England there would have been plenty. But this is an exception : the rule is, that you may read wherever you run, if you will keep your eyes and ears open, and learn by experience where chiefly to be on the look-out. Variety is more interesting than 
numbers; the birds are more obvious from their comparative rarity; and their voices are not lost, as is sometimes the case with us, in a general and unceasing chorus. As regards the number of species in the country, I have never seen an accurate computation of it. But looking over Mr. Dresser's very useful catalogue of the Birds of Europe, I calculate roughly that it would amount to about three hundred in all; i.e. less by some seventy or eighty than the avi-fauna of the British Islands. This is, however, a remarkably large number for a country that possesses no sea-board and very few of those sea-birds which form so large a contingent in our wonderful British list; and it suggests a few remarks on the causes which bring some birds to the Alps periodically, and have tempted others to make them their permanent home.

The greatest attractions for birds, and therefore the chief agents - as far as our present knowledge reaches-in inducing birds to move from place to place are food and variety of temperature. Now in the Alps we find these conditions of bird-life everywhere present, except, of course, in the very 
highest levels of snow and ice. The seed-eating birds find sufficient food in the rich hay, thick and sweet with flowers, which covers the whole of the Alpine pastures from May to July, and abundance of corn, flax, and fruit in the valleys : in the steep pine-woods that usually separate these valleys from the pastures, the larger seed-eaters enjoy an endless supply of fir-cones. The insect-eating birds are still more fortunate. Nothing is more striking in the Alps than the extraordinary abundance in the summer of insects of all kinds, as we know to our cost in the sun-baked valleys; and on the mountains it is equally wonderful though less annoying. There it is that the beetles have their paradise. In loose heaps of stone, often collected to clear a stony pasture; in the wooden palings used to separate alp from alp; in the decaying lumber of the pine-forests, beetles both small and great are absolutely swarming. A clergyman, pastor of a valley near Meiringen, who collected them, found more than eight hundred different species in his parish alone. All the birds shot for me at the Engstlen-alp had been living on a diet of minute beetles as their principal food. 
It is indeed wonderful to notice the strange disproportion between the abundance of food provided and the numbers of the birds who avail themselves of the repast: there is so much more to eat than can ever possibly be eaten.

But we must remember that this is the case only during the warm months. During the greater part of the year the snow is on the ground in the regions of which I am speaking, and hardly any birds are to be found there. A great and general migration takes place, either to the valleys below, or out of the mountain region altogether, southward, or in a very few cases, northward. Switzerland is, in fact, an admirable centre for the study of migration; migration, that is, on a large scale, where the birds leave the country entirely, and also on that limited scale which we call in England 'partial' migration. I believe that the Alps will some day win the attention of the ornithologists as being one of the best of all positions as a centre of observation. We will pause for a moment to glance at it in this light.

We need hardly look at the map to see that the 
huge mass of the Alps lies directly in the path of the great yearly migration of birds from south and east to northern Europe. The question arises at once, does this immense mountain-range, with its icy peaks and wind-swept passes, act as an obstacle to the travelling birds, or do they rise to it and cross it, without going round, into the plains of North Switzerland and Germany? I confess that I should like to be able to answer this question with greater certainty; but I believe the right answer, in the rough, to be as follows. In the first place, a large number of species never attempt to cross the mountains, but remain in the great basin of the $\mathrm{Po}$, and in southern France, the whole summer, thus making the avi-fauna of Lombardy distinct in many points from that of Switzerland. If we look through the works of Dresser, Gould, or Bree, on European birds, with the object of learning something on this point, we find that bird after bird, especially among the tenderer kinds of warblers, gets no further than North Italy and the southern slopes of the Alps, seldom straggling into Switzerland proper. On the other hand, some migrating birds, such as the 
Black Redstart, the Citril Finch, and some of the hardier warblers, seem to desire a cool climate to breed in, and doubtless come across the passes to inhabit the Alpine pastures during the whole of the summer. How far this is also the case with the vast number of more delicate birds, such as the various Reed- and Willow-warblers, who live by the rivers and lakes during the summer, I cannot undertake to say; and it is a mere guess on my part if I hazard an opinion that many of these must come into Switzerland by way of France and Austria. Anderegg sent me word last autumn that he had noticed the Swallows leaving Meiringen, not southwards over the Grimsel pass towards Italy, but westwards, as if they were seeking to turn the vast mountain barrier. Yet it is a known fact that on some of the passes birds are watched and killed in their passage.

But I have still to speak of partial or internal migration in Switzerland; and this is what, if I am not mistaken, will prove a very fertile source of ornithological knowledge when thoroughly understood. As I said before, the agents which 
chiefly cause birds to move from one place to another (so far as we know), are food-supply and temperąture. Now we have only to look at a raised map of Switzerland to see at once how subject the birds must be to such incitements towards change of place. Any one who has been to Switzerland will have noticed that the scenery falls into three great divisions-that of the lakes and valleys, that of the Alpine pastures and forests, and lastly, that of the regions on the border-line of perpetual snow, running upwards to the higher snow-fields. The professional mountaineer pays little attention to any but the last of these ; the botanist and ornithologist have, fortunately, much reason to pause and reap a harvest in the lower levels, which are incomparably more beautiful. For convenience' sake I will call the lowest, No. I ; the second-that of the Alpine pastures, No. 2 ; and the highest, No. 3. The distribution of birds in these three regions is continually changing. No. 3 , in the winter, is entirely devoid of life and food. The Eagles and the great bearded Vultures, now very rare, can find not even a marmot to prey upon, 
for they are all asleep in their burrows. The Snow-finches and the Ptarmigan, which in the summer delight in the cool air of an altitude of 8000 to 10,000 feet, have descended to No. 2, or even lower, compelled by want of food and water : and so too the red-winged Rock-creeper, the Alpine-pipit and others, which may be seen in summer close to the great glaciers. In the same way the birds which haunt No. 2 in the summer -I am speaking of those which do not leave the country altogether-descend in the autumn to No. I, and there remain till the following spring: among these are the Ring-ousel and Blackbird, the Nutcrackers, the Titmice, the Alpine Choughs, the Alpine Accentor, and others. Then in the spring the reverse process takes place. As the spring advances up the mountain-slopes, which it gains slowly, not reaching the highest region of vegetation till June or even July, the birds follow it. Region No. I, now peopled by the immigrations from Africa and the Mediterranean, sends on large numbers of its winter birds to region No. 2, where, like the cows and the herdsmen who ascend about the same time, they enjoy cool 
air and abundance of food in the well-watered pastures. Meanwhile the Snow-finches, the Ptarmigan, and the birds of prey, who have been living during the winter in the lower slopes and woods of region No. 2, retire upwards to breed in the rocks and snowy crevices of No. 3. We can hardly help believing that with all these wonderful provisions of nature for their change of scene and temperature, these partial migrants of Switzerland must lead a life supremely happy. Man himself and his cattle are partial migrants in the Alps; and no day is so welcome to the herdsman as that on which the authorities of his commune fix for the first movement of the cows upwards. Bitter indeed has been the disappointment of my old guide, now the happy possessor of two cows, when he has not been able to follow them in their annual migration to the cooler pastures. He could realize the feelings of a caged bird, unable to follow its fellows in seeking the southern lands for which its heart yearns.

Before leaving this subject I should, perhaps, note that these three regions are not divided from each other by any definite line; and in respect 
of their bird-life I need hardly say they slide insensibly into each other. But I think it will be found that the division is a fair one for our purposes, and is a useful one to bear in mind in all dealings with the natural history of the country.

I will now ask my readers to follow me mentally in an expedition which will bring us into actual contact with many of the birds I have noticed in Switzerland. We will choose a route which from its great beauty, comparative quiet, and good inns, has always been a favourite of mine, and will carry us over parts of all the three regions I have just described, enabling us to compare their avi-fauna with that of our own country. Starting from the village of Stanz-stadt, famous in Swiss history, which stands on that arm of the lake of Lucerne which lies immediately beneath Mount Pilatus, we will pass up the luxuriant valley of the $\mathrm{Aa}$, in canton Unterwalden, to Engelberg, where most of the land and forest is owned by the monks of a great monastery, whose care for their possessions has doubtless helped to make them a pleasant home 
for the birds; then we will mount to the pastures of the Gerstni-alp, in region No. 2, and so upwards to the Joch-pass, which in early summer is covered with snow, and introduces us to region No. 3. Descending for an hour to the Engstlenalp, loveliest of Swiss pastures, we find ourselves here, at the excellent inn, again in No. 2, but still within very easy reach of No. 3 ; and then we can pass downwards through the Gentelthal, or along the pastures that look down on it from the north-for there are three different ways, all of them of the rarest beauty-to the deep valley of the Aar, or Hasli-thal, where we arrive once more in region No. I.

On reaching Stanz-stadt, I always take a turn along the road that here forms a narrow causeway between two divisions of the lake, and is bordered on one side for some distance by a broad bed of reeds. Any ornithologist would see at once that something is in store for him here, and if I had had time or patience to stay here in the heat, I might probably have seen more than I did see. The Bittern occasionally visits these reeds, for the landlord of the inn showed me a very fine 
specimen which he himself had shot. They are also the summer residence of those Warblers which love reeds, and which abound much more on the reedier lakes of Biel and Neuchâtel. On my last visit to Stanz-stadt, my companion being in a hurry to get into cooler climes, I had only a quarter of an hour to spend on this bit of road; but my ear instantly caught the song of our Reedwarbler, to which I had been listening for many weeks at Oxford, while learning to distinguish it from that of its near relation the Sedge-warbler. It was pleasant to hear the familiar strain the very instant my long journey was over. The Marsh-warbler, the Aquatic-warbler, and others of their kind, are all to be seen by the rivers and lakes of our lowest region (No. I), rarely ascending higher; and he who has the courage to spend a few days in the baking and biting valley of the Rhone, for example, will find them all among the desolate reed- and willow-beds of that, to man, most inhospitable river.

Here also, at Stanz-stadt, and all up the valley to Engelberg, and at Engelberg itself in abundance, may be seen the White Wagtail of the 
continent, which is as comparatively rare in England as our common Pied Wagtail is abroad. The two forms are very closely allied, our Pied Wagtail in winter very closely resembling the White bird in its summer dress. The difficulty of distinguishing the two caused me to pay great attention to these White Wagtails whenever I saw them. If you see a bird in summer which has a uniform pearl-gray back, set off sharply against a black head, the black coming no further down than the nape of the neck, it is the White Wagtail. You must look at his back chiefly; it is far the most telling character. The male Pied Wagtail has at this season a black back, and the female has hers darker and less uniform in colour than the genuine White bird. I shall have something more to say of Wagtails in the course of our walk; but let me take this opportunity of asking the special attention of travellers on the continent to these most beautiful and puzzling birds, whose varieties of plumage at different seasons of the year seem almost endless, and whose classification is still by no means finally settled. 
As we travel up the valley to Engelberg, and in the higher portion of it in which Engelberg stands, a considerable variety of birds may be seen which are familiar to us as British species. The Whin-chat is nestling in the meadows, and swaying itself on the tops of the long grasses; our common English Redstart is seen here and there, but not often, on the walls and palings; the Creeper runs up the stems of the fruit-trees, and the Nuthatch has its nest in holes in the mapletrees, which in these valleys are of great size and beauty. In the woods and undergrowth you may see the Chiff-chaff, and Willow-wren, and Gardenwarbler, and here and there a Buzzard : the Robin and Blackbird are about, but not nearly so common as with us, and we are at first surprised at the absence of Song-thrushes, ${ }^{1}$ and the comparative rarity of Sparrows, Skylarks, and Yellowhammers.

The commonest bird of all in the Engelberg

1 This bird cannot really be wholly missing in summer, but it is strange how seldom I have seen or heard it. It is wanting also from a list sent me by Mr. A. H. Macpherson, of birds noticed by him in Switzerland last summer (1886). But Anderegg tells me that its song is often heard near his house at Meiringen. The Missel-thrush is certainly more abundant. 
valley, is one which we seldom see in England, and never in the summer. This is the Blackredstart, a bird which has a wide summer distribution all over Europe, and is found in Switzerland at all altitudes, suiting itself to all temperatures. Wherever there is a chalet under the eaves of which it can build, there it is to be found as soon as spring has begun to appear, even though the snow is lying all around. I have found it myself nesting in chalets before the herdsmen and cows had arrived there, and at a height of 6000 feet or more, it has woke me at dawn with its song: yet at the same time it is abounding in the plains of France and Germany, and nowhere have I seen greater numbers than in the park at Luxembourg. It is one of the puzzles of ornithology, that in spite of this, the bird never comes to England in the summer; and that the stragglers that do visit us always appear as winter visitants; straying to our foggy shores as if by mistake, when they ought to be on their way to the sunny south.

The little 'Röthel,' as they call him, is a great favourite with the Swiss peasantry; he is trustful and musical, and will sing sometimes when you 
are within a few feet of him. They are sorry to part with him in autumn, and cannot make out what becomes of him. One of them told me that twenty-two of these birds were once found in the winter fast asleep in a cluster, like swarming bees, in the hollow-trunk of a cherry-tree; how far the story was mythical, I will not venture to say.

The Swallow tribe have been with us all the way along the valley, but they will follow us no further. Even at Engelberg (3500 feet) they seem to be a little chilly in the early summer. When I first arrived there, in cold weather, there was not a Swift to be seen; but one morning when I woke I heard them screaming, and afterwards I always knew a fine morning by the sound of their voices. Higher up, when we leave the highest limits of region No. I, we shall see neither Swift, Martin, nor Swallow, and nothing is more striking on the 'Alps,' than the sense that you have left these birds of summer behind you. The highest point at which I saw a swallow last summer was at the glacier of the Rhone, where Anderegg pointed me out a single straggler as a curiosity: but later in the year they are probably 
bolder. Their place is taken in regions Nos. 2 and 3 by two other species, by no means common, and of great interest-the Alpine Swift and the Crag-martin. I have not found the latter in the district of which we are speaking, but he is always to be seen in a place well-known to most travellers in Switzerland-the steep descent of the Gemmi, to Leukerbad. As you wind down those tremendous precipices, you will see a little ghostly bird flitting up and down them, something after the manner of a bat, and reminding you of our Sand-martin-this is the Crag-martin, which spends the summer here, and builds in the crevices of the rocks. In the same place and others of the kind, you may see the Alpine Swift, whose flight is probably faster than that of any European bird; a splendid sight it is to watch him wheeling in the sunshine, borne along on wings that expand to a width of nearly two feet.

I have already strayed away from the valley to speak of these birds, and it is time that we should ascend to region No. 2, by the well-known path to the south of Engelberg. Just at the foot of the hill, where the path begins to mount, you 
may hear an unfamiliar note; it is that of the Pied Flycatcher, a bird not unfrequently seen in England, but welcome under all circumstances. As we go upwards through the wood, we hear very few birds : but as we suddenly emerge on a grassy slope between the pines, a large bird comes sailing high over us, with large brown outstretched wings, which we may believe is a Golden Eagle, so grave and silent its flight, so huge its outline against the sky. After half-anhour's walk we come out upon the Alps proper, $i$. $e$. the flowery pastures which form the bulk of region No. 2. Here the bird-life begins very sensibly to change. The Swallows, as I have said, do not venture so high : of the warblers, the only one left is the Chiff-chaff, which sings its familiar two notes in the underwood far up on the steep slopes above us. We are now on the 'Pfaffenwand,' a very steep and stony ascent separating the lower from the higher pastures; and here each year this tiny little bird seems to choose for his haunt, and perhaps for his nestingplace, the very highest bit of real cover, consisting only of stunted bushes, that he can find 
in all this district. Here, too, we are not unlikely to find a flock of Alpine Choughs ; noisy chattering birds, with yellow beaks, strong and stout and with a downward curve; their legs are bright red and their plumage a bright and glossy black. The Cornish Chough (Pyrrhocorax graculus, Linn.), is also found in the Alps, but it is much less common; it is a larger bird, and its bill, which is long and red, is very different from the shorter and stouter yellow beak of the smaller species. The Alpine Chough is the characteristic corvus of the Alps, as it is also of the Apennines, and its lively chatter, breaking suddenly on vast and silent solitudes, recalls to memory the familiar jackdaw we left behind us in the Broad Walk at Oxford, or in the tower of our old village church.

But as I think of those delicious pastures, nestling under the solemn precipices, and studded in June with gentians, primulas, anemones, where each breath of crystal air is laden with the aromatic scent of Alpine herbage, I seem to hear one favourite song resounding far and near-a song given high in air, and often by an invisible singer; for so huge is the mass of mountain 
around us, that he seldom projects himself against the sky in his flight, and may well escape the quickest eye. But he is never many minutes together on the wing, and will soon descend to perch on some prominent object, the very top twig of a pine, or a bit of rock amid the Alpine roses-

Those quivering wings composed, that music still.

His nest is not far off, and may sometimes be stumbled on in the grass and fern. This blithe spirit of the flowery pastures is the Water Pipit (Anthus spinoletta, Linn.), a little gray and brown bird somewhat more distinctly marked than our English Pipits, having a lightish stripe over the eye, whitish breast, and black legs; but in other respects much like his relations, both in habits and in his song, which is a long succession of clear bell-like notes, slackening somewhat in rapidity and force as he descends. He has very rarely been found in England, but may possibly be commoner than we fancy. Should I ever meet with him, he will surely carry me back in fancy to his true home among the Alps, where 
in the common speech of the peasants he is no longer a prosaic Pipit, but as he may well be called, the Alpine Lark. ${ }^{1}$

Another bird which haunts this region, though not in such numbers, and whose habits are much like those of the Water Pipit, is the Alpine Accentor. This belongs to a family (Accentoridae) which has only one other representative in Western Europe-our own familiar little Dunnock or Hedge-sparrow. In plumage and song the two are not unlike, though the Alpine bird is rather larger and of a more variegated warm - brown colouring: but I cannot help pausing for one moment to point out the remarkable instance that we have here of two very closely allied birds developing habits of life so entirely distinct,the one being stationary, the other migratory; the one breeding in the road-side hedge where it lives all the year, and the other retreating to the highest limits of the Alpine pastures and making its nest in the holes of the rocks. In the

1 This name (Alpen'erche) seems to be applied by the peasantry both to this species and to the Alpine Accentor. Mr. Seebohm, in his British Birds, calls the former, very appropriately, the Alpine Pipit. 
winter however the Alpine bird descends to the valleys, and there finds it convenient to associate more closely with man and his works; in the Hasli-thal it is known as the 'Bliem-trittel,' a term which Anderegg explained to me as meaning that it regales itself on the seeds of the flowers and grass which escape through the timbers of the chalet-built hay-barns. Thus it lives on two distinct diets in summer and winter; for in summer it feeds chiefly on the innumerable small beetles of the pastures, while in winter it is driven to become a vegetarian.

As our time is running short, we will now cross the snow-covered Joch, a pass barely high enough to bring us well into region No. 3, and drop down on the exquisite Engstlen-alp with its comfortable inn (6000 feet), whence we can climb to the highest region at any time with ease: this wellwatered and well-timbered Alp being so placed that it stands nearly at the top of region No. 2, with easy access to No. 3 , and affords us another glimpse at the former before we finally leave it.

As we sit at lunch after our walk, there faces us exactly opposite the window of the salle-d̀- 
manger, at a distance of a few yards, a little dark-brown hay-chalet; always a picturesque object, whether it stands out on a clear day against the mighty distant mass of the Wetterhörner, or looms huge and uncertain in the swirls of a mountain mist. This old friend of fourteen years' standing gained a new interest for me on my last visit. Every now and then a pair of little greenish-yellow birds would come and twitter on its roof, or pick up seeds and insects from beneath its raised floor. I took these at first for the Serin-finch, the well-known favourite cagebird of the continent, and the near relation of the Canary, and of our English Siskin. I had no wish to shoot such trustful and beautiful creatures, and therefore remained in ignorance of their true nature till I returned to England, when I found from Dresser's work that they must have been not the Serin but the Citril-finch. The two are closely allied, but the Serin seems to content itself with the valleys and plains of region No. $\mathrm{I}$, while its place is taken in the mountains by its cousin. Mr. Dresser has an interesting account of a successful search for it on the highest summit 
of the Black Forest. It builds its nest in the pine branches, but may always be looked out for near chalets or palings at a considerable height, which it ransacks for food; and an elaborate search for its nest which I made in the chalet was a wild-goose chase into which I find that more distinguished ornithologists have been misled before me.

If we now stroll out across this beautiful alp to the lake which bounds and waters it, we shall find it alive with birds. Besides the Pipits and the Accentors, there are families of young Ringousels and Missel-thrushes, which have evidently been born and brought up near at hand; Wheatears, of our English species, are perched on the big stones that lie about, and in the ancient pines above them you may now and then see a Crossbill or a Redpoll. In the broad stream that issues from the lake you will always see the Dipper, and associated with it is the Grey Wagtail, seemingly the only bird of its kind that affects the higher Alps; for the White Wagtail seems to stay in the valleys even in the summer, and to love the larger streams and the farmyard pool; 
and the other species which I might have expected to meet, the Blue-headed Wagtail (Motacilla flava, Linn.), did not once offer himself to my field-glass, nor did his near relative, our common Yellow Wagtail of spring and summer.

But it is time that we should leave the pastures and make an expedition into the higher region of rock and snow. There is of course but little bird-life there, but that little is interesting. The best way is to go straight up the steep grassslopes to the north-west of the inn, which are carpeted in June with millions of fragrant pansies and gentians, until we arrive, after a climb of some 500 feet, at a little hollow filled with snow and limestone boulders, and having on one side a precipitous wall of rock, and on the other a series of upward-sloping stretches of snow, interspersed with patches of rock and short grass. Early in the season, when this desolate region is still quite undisturbed, you may find occupation if you lie in wait awhile. In my first walk here, no sooner did I reach this hollow, than a badger got up about ten yards from me and shuffled away behind some boulders; and while following 
up his tracks over the snow, I found them crossing and recrossing the 'spur' of chamois. A little further on, I saw the Ptarmigan creeping about among the rocks, and very soon I heard the call of the Snow-finches. These birds, who thus live and breed almost within the limits of perpetual snow, might be supposed, as Gould says of them, to 'dwell in unmolested security.' I was soon able to judge of the accuracy of his statement, for as soon as I had caught sight of them with the field-glass, I saw that something was causing anxiety to the little family. It was their alarm-call that I had heard; and as I was cautiously watching them fluttering on or close to the ground, I suddenly saw a small red fox make a hungry dash upon them, startling me and causing me for the moment unwittingly to move the glass and lose the whole scene. When I found them again the fox was gone, the finches were greatly troubled, and I fear there is no doubt that he secured a dinner.

The Snow-finch is a beautiful bird, rather larger than a Green-finch or Sparrow, with long wings in which the primary quill-feathers are much longer 
than the rest, as in some other birds, of airy and graceful flight. The strong contrast of jet-black and purest white in the plumage, e.g. in the tail, which has two black feathers in the middle while the rest are as white as snow, makes the bird conspicuous at a long distance, and a more striking object than the browner Snow-bunting, which occasionally strays from the north to the Alps. Seldom have I seen a more beautiful sight, unless it be a flight of Plover on English watermeadows, than the wavings and whirings of a flock of Snow-finches, with their white feathers glistening in the sun one moment, while the next their black ones will show clear against the snow.

One other bird, which loves these great heights in the summer, may occasionally be seen within a few minutes' walk of the place where the Snowfinch fell a victim. This is the red-winged Rockor Wall-creeper, a bird so beautiful and so unique that it demands at least a passing notice. Wherever there is a steep wall or rock which is in shadow during part at least of the day, this bird may be looked for and occasionally seen, even in 
the midst of a snow-field or a glacier $;^{1}$ for when the rock is exposed to the sun, the heat generated is too great either to allow the bird to work, or the insects it seeks to remain in the crevices. To those who have not seen it, it may best be described as in shape almost exactly like our common little Tree-creeper, the only other European representative of the family, but larger, and instead of its cousin's sober brown plumage, presenting such an exquisite contrast of colour as is hardly to be found even among the fauna of the tropics. Its head, neck, and back, are soft ash-gray, and when its wings are closed you would hardly distinguish it from the gray rock to which it clings; but in an instant, as it begins half to climb and half to flutter from crevice to crevice, you will see the brilliant crimson of its lesser quill-feathers standing out, not unlike the underwings of a wellknown moth, against that delicate gray. Its bill is long and slender, but strange to say, it is without the long tongue, that wonderful far-darter, with which the wood-peckers are provided; so

${ }^{1}$ E.g. on the rocks about the Devil's Bridge near Andermatt, or on thrse of the Gemmi-pass. 
the insects which it seeks in the crevices have to be rummaged for with the bill itself, and conveyed in some mysterious manner to the tongue, which does not reach much more than half way down it. Perhaps this may partly account for a statement made to me by Anderegg, and positively insisted on by him, that the bird loses the end of its bill every autumn, regaining it in the course of the winter. I am not in a position either to accept or refute this story. Anderegg declared that he had sent Professor Fatio specimens in order to prove it; but the Professor, who has studied the bird carefully, has not, so far as I know, drawn attention to any such peculiarity. I am inclined to think the truth may lie in the liability of the bird to wear away or even break the tip of its bill in the course of its indefatigable efforts to obtain food, and I have seen a specimen in the Bern Museum whose broken bill may possibly be a confirmation of this explanation. The peasant mind is apt enough to elevate an accidental circumstance into a law of nature.

We must now leave region No. 3 altogether, and descend from the Engstlen-alp westwards 
towards the Hasli-thal, passing through long stretches of the pine-forests which so often separate the upper pastures from the valleys. There are two families of birds to be met with in these forests, of which I must say a very few words,the Woodpeckers and the Titmice. The former are not abundant, and it needs much patience to find them. I was to have visited a nestingplace of the Great Black Woodpecker (that aweinspiring bird, which has borne its name of Picus Martius ever since it was the prophetic bird of Mars ${ }^{1}$ ), but fate decreed that I should have to go that day in an opposite direction. The three Spotted Woodpeckers-great, middle, and lesser -all occur, but our familiar green bird, which does not seem at home among the pines, is less common. Rarest of all is the Three-toed Woodpecker, with yellow head, which dwells-so An-

1 In common with other Woodpeckers, as Mr. H. Wharton has reminded me in the Academy. It is indeed very doubtful whether this striking bird was known either to Aristotle or Pliny; it is now an uncommon bird in Italy, and is properly an inhabitant of northern Europe. But when Italy was covered with forest (cp. Theophrastus, Hist. Plant. v. 8. 2) it must have been known t3. the country people. 
deregg told me, and I find from the books that he was right-only among the highest and most solitary pine-woods.

At intervals, as in an English wood, the trees will be astir with Titmice. The Cole-tit and the Marsh-tit, the Blue-tit and the Great-tit, are all to be seen here, the last two undistinguishable from the British form, while the Cole-tit has a bluer back than ours, and the Marsh-tit in these higher levels differs, according to Professor Fatio, even from the same bird when found lower down, and approaches rather to the Scandinavian form. This single fact is enough to show how interesting would be a persevering study of this particular family. I will not venture to say whether these slight differences in plumage are enough to justify a specific separation of the forms. In the case of the continental Long-tailed Tit, which is decidedly different in colouring from ours, even amateurs may perhaps see a sufficient reason; but will prefer to suspend their judgment as to the other two.

There is yet a Titmouse, nearly always to be heard and seen between the Engstlen-alp and the 
Gentelthal, which is even more attractive to the ornithologist than any of its cousins. This is the Crested-tit (Lophophancs cristatus, Linn.), now so rare even in Scotland, and, according to Anderegg, not too common even in these pine-forests. It needs a vigilant eye and ear to detect it, so closely does it resemble its relatives (and especially the Blue species) both in voice and appearance, until you catch the well-marked crest on the head, and the additional shade of melancholy in the note. So close indeed are this bird and the Blue-tit in form, habits, and note, that I am astonished that the crest by itself ( $a$ few feathers raised on the head) should have been thought a sufficiently strong character to raise it into a separate genus-Lophophanes. If we notice the Blue-tit carefully, we shall find that he also often elevates his head-feathers into something like a crest; imagine this a little larger, and the bright colouring of the Blue-tit sobered into a soft bluish gray, and you will get a very good idea of the appearance of the male Crested-tit. His lady is brown rather than gray, causing Anderegg to make one of those mistakes to which the peasant- 
naturalist is liable; he assured me that there were two species, answering to the two prevailing tints.

I never can forget the spot where my old friend's sharp ear first caught for me the quiet note of these little birds. If any bird-lover should chance to walk from Engstlen down to the Haslithal, he should stop near the foot of the first rapid descent among the pines, where the stream which he has lately crossed tumbles over a ledge of rock into a deep dark pool. At the very edge of this pool stand a few black pine-trees, and among the thick branches of these the Tits were playing. Above us were vast mountain walls, and at our feet was the mossy grass, damp with the spray of the fall; among the gray boulders the alpine rhododendron was coming into bloom. At a little distance a robin was singing its ever-welcome song, mingling its English music with the sound of alpine cow-bells from the pasture further down the valley. Such scenes linger for ever in the memory, and are endeared to us by the thought of the blithe creatures who live and sport among them during a long golden summer, long after we 
have returned to the land of misty meadows and miry ways.

But we must now leave these woods and pastures, and descend to the deep valley of the Hasli-thal, where we shall end our journey at Meiringen. If, instead of following the ordinary path, we skirt along the heights to the north towards Hasliberg, and so keep in cooler air, enjoying endless views, we shall finally descend by a very steep winding path, which is the only means of communication between the population of the valley and that of the higher slopes. In the willows and hazels among which this path winds, and also on the opposite side of the valley on the way to Rosenlaui, I have always heard a little warbler whose voice was quite strange to me. More than once I have done all I could to obtain a good sight of it ; but the restless caprice of these little birds, who flit rapidly in and out of the bushes while the ornithologist waits with his head in a burning sun, only to lose sight of the tiny creature the moment the glass is upon him, defeated my purpose of finding out his species beyond the possibility of error; and Anderegg 
was as unwilling to use his gun so near the village, as I should have been to sacrifice a joyous life to the spirit of curiosity. But I have every reason to believe that my little tormentors belonged to a species with which I shall hope somre day to make a closer acquaintance; it bears the name of the Italian naturalist Bonelli, and is a very near relation of our friends the Chiff-chaff and Willowwren (Phylloscopus Bonnellii, Vieill.). ${ }^{1}$

Our walk is now ended, and this chapter is already quite long enough. Were we to take another, we might see many other species not less interesting than those we have met with on the way from Stanz-stadt; we might find Hawks of several species, Nutcrackers in the pine-woods, the Golden Oriole, the Hoopoe, or the beautiful Blue-breast. But I have thought it better to be content, for the most part, with the birds I have

${ }^{1}$ The closer acquaintance has been made, and I have learnt the song of this bird, which is not unlike that of the Lesser White-throat described in Chapter II. Of all the warblers I know, this is the most restless and difficult to observe when once the leaves are fully out. It is the only bird, I think, which has completely baffled me during a whole morning spent in pursuing the song without once getting a fair look at the singer. (June, r889.) 
actually met with in the walk we have chosen to take, rather than to furnish a catalogue of all those we might be lucky enough to meet with if we stayed some weeks in the country. And thus I hope I may have given my readers some little idea of the impression left by the birds of a wellknown alpine district on the memory of a rather hurried traveller, who has not been always able to go or to stay as his own inclination would prompt him.

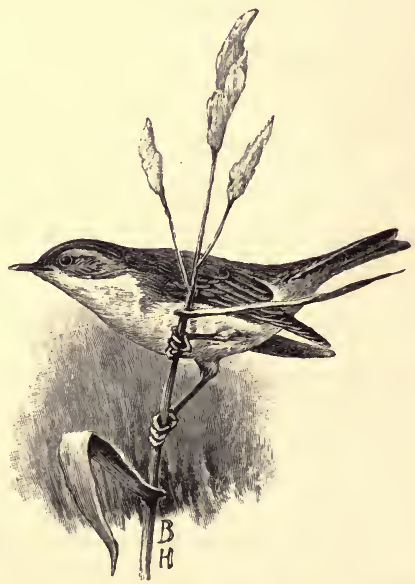

Bone.li's Warbler. 


\section{CHAPTER IV.}

\section{A MIDLAND VILLAGE: GARDEN AND MEADOW.}

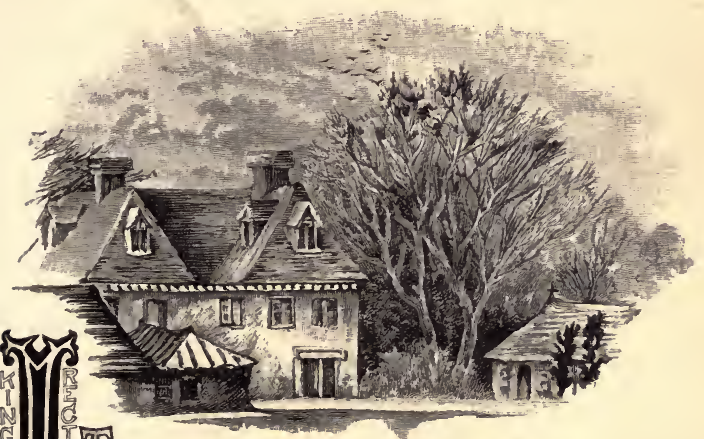

is a curious fact that, when I return from Switzerland, I am at first unable to discover anything in our English midlands but a dead level of fertile plain. The eye has accustomed itself in the course of two or three weeks to expect an overshadowing horizon of rock and snow, and when that is 
II4 A Midland Village: Garden and Meadow.

more than a ditch; but shortly after passing the historic lawns of Daylesford, it is joined by two other streams, one descending from the slope of the Cotswolds, and the other from the high ground of Chipping Norton eastwards. These two join the Evenlode exactly at the point where it enters Oxfordshire, and the combination produces a little river of some pretension, which enjoys a somewhat more rapid descent for some miles from this junction, and almost prattles as it passes the ancient abbey-lands of Bruerne and the picturesque spire of Shipton church.

Close to the point of junction, on a long tongue of land which is a spur of Daylesford hill, and forms a kind of promontory bounded by the meadows of the Evenlode and the easternmost of its two tributaries, lies the village where much of my time is spent in vacations. It is more than four hundred feet above the sea, and the hills around it rise to double that height; but it lies in an open country, abounding in corn, amply provided with hay-meadows by the alluvial deposit of the streams already mentioned, and also within easy reach of long stretches of wild woodland. 
For all along the valley the observant passenger will have been struck with the long lines of wood which flank the Evenlode at intervals throughout its course; he passes beneath what remains of the ancient forest of Wychwood, and again after a considerable gap he has the abbey-woods of Bruerne on his left, and once more after an interval of cultivation his view is shut in by the dense fox-covers of Bledington and Oddington, the border villages of Gloucestershire. It is just at this interval between Bruerne and Bledington that the junction of the two streams with the Evenlode takes place; so that from this point, or from the village already spoken of, it is but a short distance to an ample and solitary woodland either up or down the valley. Beyond that woodland lies a stretch of pasture land which brings you to the foot of the long ridge of hill forming the north-eastern boundary and bulwark of the Cotswolds, and hiding from us the little old-world towns of Burford and Northleach. We have therefore within a radius of five or six miles almost every kind of country in which birds rejoice to live. We have water-meadow, corn- 
112 A Midland Village: Garden and Meadow.

removed, it fails to perceive the lesser differences of height. This fact is an excellent illustration of the abnormal condition of things in the Alps, affecting the life both of the plants and animals which inhabit them; and it also shows us how very slight are the differences of elevation in most parts of our own island. In ordinary weather, the temperature does not greatly differ in an English valley and on an English ridge of hill, and the question whether their fauna and flora vary, is one rather of soil than of temperature. Still, there are manifest differences to be observed as we proceed from river-valleys to rising wooded ground, and from this again to a bare hill-side; and it may be interesting, after our walk in the Alps, to note the bird-life of an English rural district which is provided with all three, recalling dimly and perhaps fancifully the three regions of the Alpine world.

The traveller by railway from Oxford to Worcester leaves the broad meadows of the Isis about three miles above Oxford, and after çrossing a spur of higher land, strikes the little river Evenlode at Handborough Station, not far 


\section{A Varied Country-side.}

from its junction with the Isis at Cassington. This Evenlode is the next considerable stream westward of the Cherwell, and just as the line of the latter is followed by the Birmingham railway, so the line to Worcester keeps closely to the Evenlode for nearly twenty miles, only leaving it at last in its cradle in the uplands of Worcestershire. Westward again of the Evenlode, the Windrush comes down from the northern Cotswolds, to join the Isis at Witney, and further still come Leach, and Coln, and others, bringing the clear cold water in which trout delight, from the abundant springs at Northleach and Andoversford. But the Evenlode is not a Cotswold stream, though trout may still be caught in it where it has not been polluted; it skirts for many miles the north-eastern slope of the Cotswolds, which may be seen from the train-windows closing in the horizon all the way from Shipton-underWychwood to Evesham and Worcester, but it has the slow current and muddy bottom of a lowland stream, and runs throughout its course among water-meadows liable to flood.

For the first few miles of its course it is little 
I 6 A Midland Village: Garden and Meadow.

land, woods, and hills, and also here and there a few acres of scrubby heath and gorse; and the only requisite we lack is a large sheet of water or marshy ground, which might attract the waders and sea-birds so commonly found near Oxford. We are neither too far north to miss the southern birds, nor too far south to see the northern ones occasionally; we might with advantage be a little farther east, but we are not too far west to miss the Nightingale from our coverts.

Such a position and variety would be sure to produce a long list of birds, both residents and visitors; not only because there are localities at hand suited to be their dwelling-places during the whole or a part of the year, but because they offer the change of scene and food which is essential to the welfare of many species. An open country of heath and common will not abound in birds of more than a very few species, unless it is varied with fertile oases, with garden, orchard, or meadow ; for many of the birds that delight to play about in the open, and rove from place to place during the first few months of their existence, will need for their nests and young the 
shelter of trees and shrubs. While the young are growing, they require incessant feeding, and the food must be at hand which they can best assimilate and digest; and it does not follow that this is the same as that which the parents habitually eat, or which the young themselves will most profit by when they are fledged. The relation between the movements of birds and their food is a problem which has not, so far as I know, been fully investigated as yet. Other problems of absorbing interest at present occupy the attention of men of science. The sure foothold which has been gained by the theory of development has placed the great questions of classification in a new light, and brought the structure of animals into the foreground; the microscope each year discovers new wonders in the development of that structure from the earliest visible germ of life, and the habits of the living animal, ${ }^{1}$ and the relations of animals to each other, have consequently fallen a little into the background. No ornithological researches, so far

${ }_{1}$ Mr. Seebohm's British Birds is a remarkable exception to this tendency. 
I 8 A Midland Village: Garden and Meadow.

as I am aware, have been lately published in this country, which can compare with those of Sir J. Lubbock on the intelligence of insects. Birds are in fact an extremely difficult subject for minute study; abundant leisure at the proper season, indefatigable perseverance, and the means and opportunity of travel, are its necessary conditions, which are denied to most men. And, it must be added, a considerable sacrifice of the life and happiness of birds is another sine qua non of investigations of this kind; and thus the growing sensitiveness of cultivated men is brought into conflict with the ardour of the enthusiastic savant.

But to return to my village; it is astonishing how many birds, in spite of the presence of their deadliest enemies, boys and cats, will come into our gardens to build their nests, if only fair opportunities are offered them. In a garden close to my own, whose owner has used every means in his power to attract them, ${ }^{1}$ there were last May fifty-three nests, exclusive of those of swallows

1 This kindly patron of birds is E. D. Lockwood, Esq., late of the Bengal Civil Service, and author of Natural History, Sport, and Travel in India. 
and martins. The garden is not more than two or three acres in extent, including the little orchard which adjoins it; but by planting great numbers of thick bushes and coniferous trees, and by placing flower-pots, old wooden boxes, and other such odds and ends, in the forks of the branches at a considerable height from the ground, he has inspired them with perfect confidence in his goodwill and 'philornithic' intentions. The fact that a pair of Missel-thrushes reared their young here only a few feet from the ground, and close to a stable and a much-frequented walk, shows that even birds of wild habits of life may be brought to repose trust in man by attention to their wants and wishes. The Blackcap, which almost always nests in woods, had here found it possible to take up its quarters close to the fruit it loves; and of all the commoner kinds the nests were legion. Three Greenfinches built in the same tree one over another, the nests being little more than a foot apart; a Wren had so closely fitted a little box with the usual materials of its nest, that the door corresponded with the only opening in the box; a Robin had found an ample basis of 
construction in the déserted nest of a Blackbird. The only bird that had been forbidden access to this Eden was the Bullinch; he duly made his appearance, but was judged to be too dangerous to the buds of the fruit-trees. Siskins and Hawfinches have occasionally looked into this garden; but the Hawfinch has never bred here, and for some unexplained reason the same is the case with the Redstart.

In my own garden, within a few feet of the house, this last-mentioned friend found a very convenient abode in a hole in my largest appletree. The parents became very tame, and when they knew their young were discovered, made very little scruple about exposing themselves in going in and out. The food they brought their young, whenever we happened to see it, was a small green caterpillar; and I sincerely hope we may have them again next year, both for the benefit to my garden and for the pleasure they give me. ${ }^{1}$ May the sad loss of one fledgling

1 They came, but found the hole occupied by the ubiquitous Starling. He again gave way to a pair of bold Blue-tits, who brought up their young here, flitting about the garden like large blue butterflies. 
depart from their memory before next summer! It was just launched into the world when it fell a victim to my dog, for I had seen it in the nest only an hour or two before; I had left strict injunctions for the confinement of all domestic animals as soon as the young were seen to leave the nest, but had not expected them to face the world so soon. This was a beautiful little bird, showing already the rich russet colour in what he had of tail ; his legs and claws were of extreme slightness and delicacy, and his whole colouring and framework was far more engaging than is the case with most young birds of his age. He had already picked up, or had been given by his mother, a pebble or two to assist his digestion.

The Redstart was not a very common bird about us until about three years ago, but now its gentle song is heard in May in almost every garden and well-hedged field. In August and September the young birds are everywhere seen showing their conspicuous fire-tails as they flit in and out of the already fast-browning hedges; yet three or four years ago my daily walks did not discover more than a few dozen in a summer. 
I22 A Midland Village: Garden and Meadow.

What can be the cause of this surprising increase of population? If it is anything that has happened in this country, such as the passing of the Wild Birds' Protection Act, we must suppose that the same individuals which breed and are born here in one spring, return here the next year; i.e. our supply of this summer migrant depends on the treatment it receives here, and not upon the number of Redstarts available in the world generally. I am inclined indeed to think, though it is difficult to prove it, that the wholesale slaughter of young birds in our neighbourhood is less horrible than it used to be before the passing of the Act; but when we remember that other creatures, certain butterflies, for example, whose relations to man never greatly differ from year to year, are found to be much more abundant in some years than others, the more rational conclusion seems to be, that an increase or decrease of numbers depends, in the case of migrating birds, on certain causes which are beyond the reach of mankind to regulate. What these may be it is possible only to guess. A famine in the winter quarters would rapidly decimate the numbers of 
those individuals which were with us last summer, and we cannot tell whether the deficiency would be supplied from other sources. Even a severe storm in the spring or autumn journey would destroy an immense number of birds so tender and fragile; and we must not forget that these journeys take place at the very seasons when storms are especially frequent and violent. Any very serious alteration in the methods of dealing with the land in this country, such as the substitution of railings or ditches for hedges, or the wholesale felling of woods and copses, would also most certainly affect the numbers of this and most other birds; but in the course of the last few years no such change of any magnitude has taken place, and the increase of the Redstarts must be put down, I think, to causes taking effect beyond the sea.

The only really annoying destruction of hedges in our immediate neighbourhood within my recollection is one for which I ought always to be grateful, for it brought me a sight of the only Black Redstart I have ever seen in England. I mentioned in the last chapter that this little bird, 


\section{I24 A Midland Village: Garden and Mecdow.}

which is so abundant on the Continent all through the summer, never comes to this country except in the autumn, and then only in very small numbers, chiefly along the south-west coast. It is generally seen in Dorset, Devon, and Cornwall in November, but never breeds there, and it is seldom that a straggler finds his way further north. On the 6th of November, I884, I was returning from a morning walk, and about a milc from the village came to a spot which a few years ago was one of the prettiest in the country-side. Here one road crosses another, and formerly the crossing was enclosed by high hedges and banks, forming a comfortable nook where the hounds used to meet, and where the Sand-martins bored their way into the light and sandy soil. A landagent descended here one day, like a bird of ill omen, and swept the hedges away, filling their place with long lines of bare and ugly wall; the martins sought a lodging elsewhere, for they could no longer feed their young with the insectlife of the hedgerows; the hounds followed their example, and all my associations with the spot were broken. But it was upon this very wall, 
new, useful, straight, and intensely human, that this rare little bird chose to sun himself that bright November morning. A thousand times have I seen him on the old gray fern-covered walls of the Alpine passes, but never did I expect to see him on this hideous 'improvement' of civilization. Except that he was silent and alone, he seemed as much at home here as on the flowery slopes of the Engstlen-alp. There is nothing that man can erect that is too uncomely for the birds. ${ }^{1}$

I have digressed for a moment to teli this tale of the Black Redstart, but I have hardly yet done with the village itself. We have of course plenty of Robins and Hedge-sparrows breeding in our gardens, and in the nests of these the Cuckoo is fond of depositing its egg. It would not be always true to say that the Cuckoo lays its egg in its victim's nest, for in some instances at least the egg is dropped from the bill. A

1 For exactly four years I saw no other Black Redstart in Oxfordshire. But on November 5, 1888, another caught my eye within half a mile of the spot described in the text. This time it was another new and ugly wall that he patronized, transferring his attention now and then to the cabbages in a cottage garden hard by. 
Robin built its nest in a hole in the wall of my garden, several inches deep, and with a rather narrow entrance; several eggs were laid and all was going well. It was three or four days from my first knowledge of the nest to my second visit, when I was greatly annoyed to find all the eggs but one on the ground at the foot of the wall, broken to fragments. I accused the boy who filled the office of boot-cleaner; he was more or less of a pickle, but he positively denied all complicity. Meanwhile in my indignation I had forgotten to examine the remaining egg ; but the mystery was soon solved. Noticing that the Robins had not deserted, I looked again after awhile, and found a young Cuckoo. The ugly wretch grew rapidly, and soon became too big for the nest, so we hung him up in a basket on a branch, where the Robins continued to feed him. His aspect and temper were those of a young fiend. If you looked at him he would swell with passion, and if you put your finger towards him, he would rise up in the basket and 'go for it.' One fine morning he disappeared, and was never heard of more. 
In this case the egg was unquestionably deposited with the bill, while the same instrument must have been used to eject the Robin's eggs, thus saving the young Cuckoo when hatched the trouble of getting rid of the young Robins by muscular exertions. Next year a Cuckoo's egg was laid in a Hedge-sparrow's nest in an adjoining garden; but the intended foster-parents wisely deserted, and I was able to take possession of the nest and eggs. Every year in June we are sure to notice a persistent cuckooing close by us, and nearly every year an egg is found in some nest in the village. Once ( $\mathrm{I}$ think it was at the time when the Robin was the victim) boys reported that they saw a cuckoo sitting on a bough hard by, with an egg in its bill. There is no doubt whatever that the bill can hold the egg, which is hardly as large as a starling's.

We have another much smaller bird in the village which can hold large objects between its mandibles - objects almost as large, and some-

${ }^{1}$ The discovery in Germany (see the Ibis for April, 1889) of a Cuckoo hatching its own egg should put all English observers on the look-out. We have taken it too much for granted that such a thing could not happen. 


\section{I28 A Midland Village: Garden and Meadow.}

times more bulky, than the egg of the Cuckoo. This is the Nuthatch, which will carry away from a window any number of hard dessert nuts, and store them up in all sorts of holes and corners, where they are sometimes found still unbroken. These plump and neat little birds, whose bills and heads and necks seem all of a piece, while their bodies and tails are not of much account, have been for years accustomed to come for their dinners to my neighbour's windows. ${ }^{1}$ One day while sitting with my friend, Col. Barrow, F.R.S. (to whom the Oxford Museum is indebted for a most valuable present of Arctic Birds), we set the Nuthatches a task which at first puzzled them. After letting them carry off a number of nuts in the usual way, we put the nuts into a glass tumbler. The birds arrived, they saw the nuts, and tried to get at them, but in vain. Some invisible obstacle was in the way; they must have thought it most uncanny. They poked and

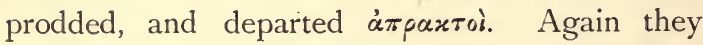

1 Col. Barrow tells me that now (August, I 886) they have come to prefer bread to nuts, and will leave the latter so long as they can get the former. 
came, and a third time, with the like result. At last one of them took his station on a bit of wood erected for perching purposes just over the lintel ; he saw the nuts below him, down he came upon

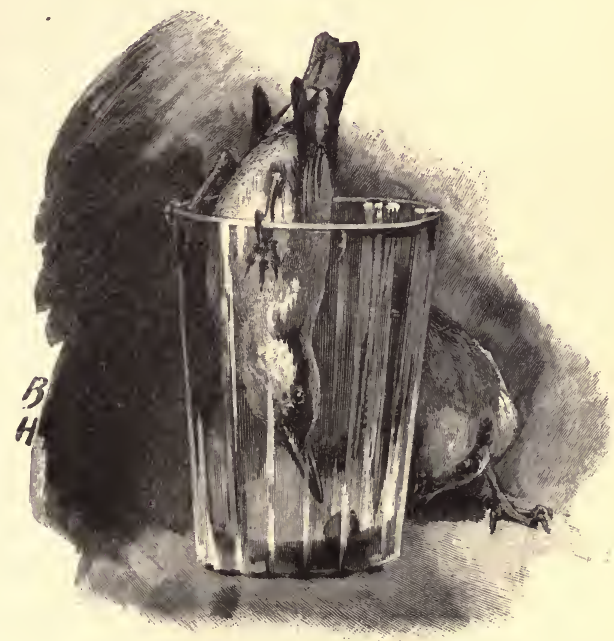

the tumbler's edge, and in a moment his long neck was stretched downwards and the prize won. The muscular power of the bird is as well shown by this feat, as his perseverance and sagacity by 


\section{I30 A Midland Village: Garden and Meadow.}

the discovery of the trick; for holding on by his prehensile claws to the edge of the tumbler, he contrived to seize with his bill a large nut placed in the bottom of it, without any assistance from his wings; the length of the tumbler being little less than that of the bird. But after all, this was no more than a momentary use of the same posture in which he is often to be seen, as he runs down the trunks of trees in search of insects.

The Spotted Flycatcher is another little bird which abounds in our gardens and orchards; it is always pleasant to watch, and its nest is easy to find. One pair had the audacity to build on the wall of the village school: it was much as if a human being should take up his residence in a tiger's jungle, but if I recollect right, the eggs and young escaped harm. Another pair placed their nest on a sun-dial in Col. Barrow's garden, as late as mid-July. This Flycatcher is the latest of all the summer migrants to arrive on our shores $;^{1}$ the males and females seem to come

1 When does he leave us? On Aug. 23, 1886, I saw an astonishing number of Flycatchers all on the same side of an 
together, and begin the work of nesting at once,

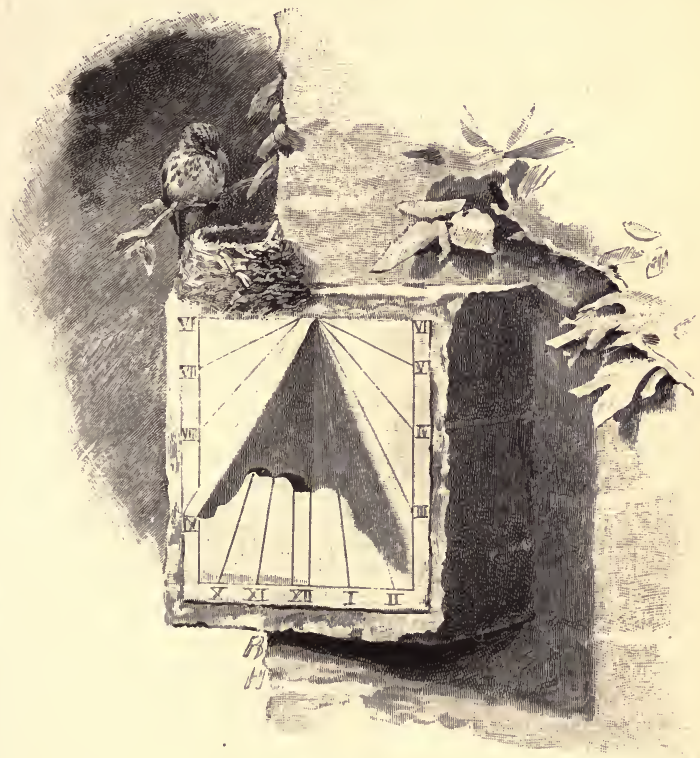

Nest on sun-dial.-p. 130.

i.e. in the middle of May; if the nest is taken, orchard, and felt sure, from their restlessness, that they had assembled, as swallows do, in view of migration. On the $24^{\text {th }}$ I went to S. Wales, where, during a whole week, I only saw 


\section{I32 A Midland Village: Garden and Meadow.}

as was probably the case with this pair, the second brood would not be hatched till July. The bird is singularly silent, never getting (within my experience) beyond an oft-repeated and halfwhispered phrase, which consists of three notes, or rather sounds, and no more ; the first is higher and louder than the others, which are to my mind much like that curious sound of disappointment or anxiety which we produce by applying the tongue to the roof of the mouth, and then suddenly withdrawing it. But is the Flycatcher always and everywhere a silent bird ? ${ }^{1}$ It is most singular that he should be unattractive in colour also-gray and brown and insignificant; but perhaps in the eyes of his wife even his quiet voice and gray figure may have weight.

one, though they were abundant up to that time. Letters from ornithological friends led me to believe that the birds have almost entirely disappeared from South and East England $b_{j}$ about Sept. I 2 ; and Mr. Seebohm is probably right in giving the first week of September as the usual date of their departure. How much less we know of the departure than of the arrival of birds, so quietly do they slip away!

1 Mr. Seebohm (Brit. Birds, i. 325) tells us of a quiet little warble, so low as to be scarcely heard at a few yards' distance ; but this I have never yet succeeded in catching. 
This Flycatcher is an excellent study for a young ornithologist. He is easily seen, perching almost always on a leafless bough or railing, whence he may have a clear view, and be able to pick and choose his fies; and he will let you come quite close, without losing his presence of mind. His attitude is so unique, that I can distinguish his tiny form at the whole length of the orchard; he sits quietly, silently, with just a shade of tristesse about him, the tail slightly drooped and still, the head, with longish narrow bill, bent a little downwards, for his prey is almost always below him; suddenly this expectant repose is changed into quick and airy action, the little wings hover here and there so quickly that you cannot follow them, the fly is caught, and he returns with it in his bill to his perch, to await a safe moment for carrying it to its young. All this is done so unobtrusively by a little grayishbrown bird with grayish-white breast, that hundreds of his human neighbours never know of his existence in their gardens. $\mathrm{He}$ is wholly unlike his handsomer and livelier namesake, the Pied Flycatcher, in all those outward character- 
I34 A Midland Village: Garden and Meadow.

istics which attract the inexperienced eye; but the essential features are alike in both, the long wing, the bill flat at the base, and the gape of the mouth furnished with strong hairs, which act like the backward-bent teeth of the pike in preventing the escape of the prey.

Our village is so placed, that all the birds that nest in our gardens and orchards have easy and immediate access to a variety of feeding-grounds. From my window, as I write, I look over the village allotments, where all kinds of birds can be supplied with what they need, whether they be grain-eating or grub-eating; here come the Rooks, from the rookery close by, and quite unconscious of my presence behind the window, and regardless of the carcases of former comrades which swing on some of the allotments, they turn out the grubs with those featherless white bills which are still as great a mystery as the serrated claw of the Nightjar.

Here also come the Wood-pigeons, and in late summer the Turtle-doves-far worse enemies to the cottager than the rooks; here all the common herd of Blackbirds, Thrushes, Sparrows, 
Chaffinches, and Greenfinches, help to clear the growing vegetables of crawling pests at the rate of hundreds and thousands a day, yet the owners of the allotments have been accustomed since their childhood to destroy every winged thing that comes within their cruel reach. Shortsighted, unobservant as they are, they decline to be instructed on matters of which they know very little, but stick to what they know like limpets. For my part, I decline to protect my gooseberries and currants from the birds; their ravages are grossly exaggerated, and what they get I do not grudge them, considering their services during the rest of the year. ${ }^{1}$

Beyond the allotments the ground falls to the brook which I mentioned as descending from Chipping Norton to join the Evenlode. This brook is dammed up just below to supply an old flour-mill, and has been so used for centuries; its bed is therefore well lined with mud, and when the water is let out, which often happens (for the

1 This year (1886) I took all the sparrows' nests on my house, and examined the young birds. Only one or two young peas and grains had been given them : they had been fed largely on insects. 


\section{I36 A Midland Village: Garden and Meadow.}

mill is on its last legs, and supports itself by aid of a beer-license which is the plague of the village), this mud appears in little banks under the shelving rat-riddled lip of the meadow. Here is a chance for some of the more unusual birds, as every ornithologist would say if he saw the stream; but both water and mud are often thick with the dye from the Chipping Norton tweed-mill, and no trout will live below the point at which the poisoned water comes in. Strange to say, the poisoning does not seem to affect the birds. Two pairs of Gray Wagtails, which I seldom see in the Evenlode, passed a happy time here from July to December last year, preferring some turn of the brook where the water broke over a few stones or a miniature weir; and through August and September they were joined by several Green Sandpipers. These beautiful birds, whose departure I always regret, are on their way from their breeding-places in the North to some winter residence; they stay only a few weeks in England, and little is known about them. Many a time have I stalked them, looking far along the stream with a powerful glass in hopes of catching them 
at work with their long bills; each effort comes to the same provoking conclusion, the bird suddenly shooting up from beneath your feet, just at a place which you fancied you had most carefully scanned. When they first arrive they will fly only to a short distance, and the bright white of their upper tail-feathers enables you to mark them down easily for a second attempt ; but after a few days they will rise high in the air, like a snipe, when disturbed, and uttering their shrill pipe, circle round and round, and finally vanish.

It should be noted that this species is called the Green Sandpiper because its legs are green; such are the wilful ways of English terminology. ${ }^{1}$ It is the only Sandpiper we have, beside the common species, which invariably prefers the Evenlode, where it may every now and then be seen working its rapid way along the edge of the water, quite unconcerned at a spectator, and declining to go off like a champagne cork. Both kinds come in spring and late summer, but the

1 Mr. Aplin tells me, however, that the upper parts, in summer at least, "have a decided wash or gloss of green": Mr. Seebohm calls it "dull olive-brown." 


\section{I38 A Midland Village: Garden and Meadow.}

Green Sandpiper is much more regular in his visits, and stays with us, in autumn at least, much longer. A stray pair found their way here last winter in a hard frost, and rose from beneath my feet as I walked along the Evenlode on December 24 th. This is the only time I have ever seen them here except in the other brook; and I have very little doubt that they were total strangers to the locality. Had they ever been here before, I make bold to say that they would have gone to their old haunts.

Beyond the brook lies a magnificent meadow nearly a mile long, called the Yantle, in which, a century and a half ago, the little Warren Hastings used to lie and look up with ambitious hopes and fears at the hills and woods of Daylesford. This meadow was once doubtless the common pasture ground of the parish: it now serves as ager publicus for great numbers of winged families bred in our gardens and orchards. Goldfinches, linnets, starlings, redstarts, pipits, wagtails, whitethroats, and a dozen or two of other kinds, spend their whole day here when the broods are reared. The Yellow Wagtails are always conspicuous 
objects; not that they are brilliantly coloured, for the young ones are mostly brown on the back, and would hardly catch an inexperienced eye, but because of the playfulness of their ways and their graceful, wavy flight. Young birds play just like kittens, or like the fox-cubs I once caught playing in Daylesford wood at the mouth of their earth, and watched for a long time as they rolled and tumbled over each other. Only yesterday (July I 5, I 885) I watched a host of young willow-wrens, whitethroats, titmice, and others, sporting with each other in a willow-coppice, and mixing together without much reserve. Once I was taken aback by the sight of two young buntings at play; for a time they quite deceived me by their agility, fluttering in the air like linnets, unconscious that a single winter was to turn them into burly and melancholy buntings. The student of birds who sighs when the breeding season is over and the familiar voices are mute, is consoled by the sight of a!l these bright young families, happy in youth, liberty, and abundance. His knowledge, too, is immensely increased by the study of their habits and appearance. His sense of the ludicrous is 
I40 A Midland Village: Garden and Meadow.

also sometimes touched, as mine was yesterday when I went to see how my young swallows were getting on under the roof of an outhouse, and found them all sitting in a row on a rafter, like school-children; or when the young goldfinches in the chestnut tree grew too big for their nest, but would persist in sitting in it till they sat it all out of shape, and no one could make out how they contrived to hold on by it any longer. Young birds too, like young trout, are much less suspicious than old ones, and will often let you come quite close to them. In Magdalen Walk at Oxford the young birds delight to hop about on the gravel path, supplying themselves, I suppose, with the pebbles which they need for digestion; and here one day in July a young Robin repeatedly let me come within two yards of him, at which distance from me he picked up a fat green caterpillar, swallowed it with great gusto, and literally smacked his bill afterwards. The very close examination thus afforded me of this living young Robin disclosed a strong rufous tint on the tail-coverts, of which I can find nothing in descriptions of the bird; if this is usually the 
case, it should indicate a close connection with the Redstarts, the young of which resemble the young Robin also in the mottled brown of the rest of their plumage.

Our meadows are liable to flood occasionally in the winter, and also in a summer wetter than usual. One stormy day in July, some years ago, I espied two common Gulls standing in the water of a slight flood, apparently quite at home. But our Rooks found them out, and considering the Yantle sacred to themselves and such small birds as they might be graciously pleased to allow there, proceeded to worry them by flying round and round above them incessantly until the poor birds were fain to depart. Rooks are very hostile to intruders, and quite capable of continued teasing ; I have watched them for a whole morning per. secuting a Kestrel. No sooner did the Kestrel alight on the ground than the Rooks 'went for it,' and drove it away; and wherever it went they pursued it, backwards and forwards, over a space of two or three miles.

In winter the floods will sometimes freeze. One very cold day, as I was about to cross the 
I42 A Midland Village: Garden and Meadow. ice-bound meadow, I saw some little things in motion at the further end, like feathers dancing about on the ice, which my glass discovered to be the tails of a family of Long-tailed Tits.

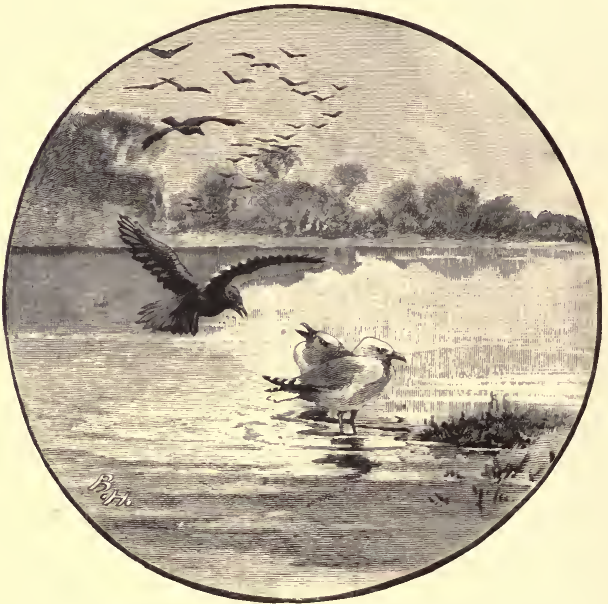

I nt our Rooks found them out, and . . proceeded to worry them.-p. IfI.

They were pecking away at the ice, with their tails high in the air. As I neared them they flew away, and marking the place where they were at work, I knelt down on the ice and examined it 
with the greatest care. Not a trace of anything eatable was to be found. Were they trying to substitute ice for water? Not a drop of water was to be found anywhere near. I have seen Fieldfares and Redwings doing the same thing in Christ Church meadow at Oxford, but the unfrozen Cherwell was within a few yards of them. ${ }^{1}$ Whether or no the Long-tails were trying to appease their thirst, I may suggest to those who feed the starving birds in winter, that they should remember that water as well as food is necessary to support life.

The Yantle is a great favourite with Plovers, Turtle-doves, and Wood-pigeons, and in the winter it is much patronized by Fieldfares and Redwings. And a day or two ago I surprised four Curlew here (March 2 I), on their way from the sea to their inland breeding-places. But enough of the village and its gardens and outlying meadows; in the next chapter we will stroll further afield.

${ }^{1}$ Stone-chats have been observed busy in this way near Oxford.-A. H. M. 


\section{CHAPTER V.}

A MIDLAND VILLAGE: RAILWAY AND WOODLAND.

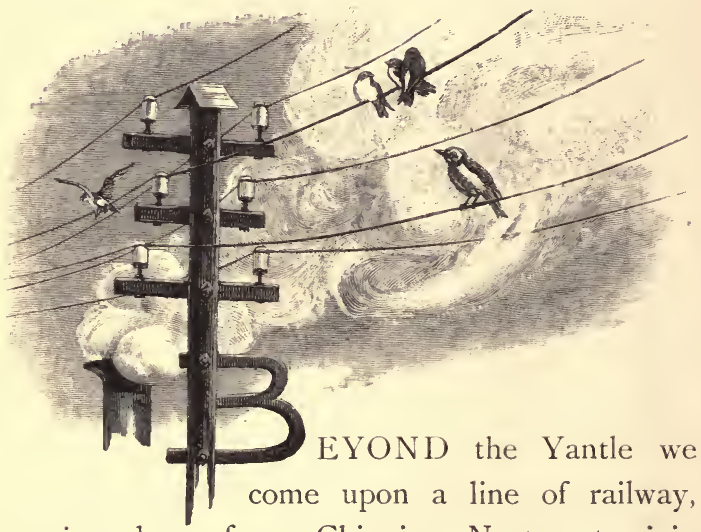

running down from Chipping Norton to join the main line to Worcester. Just as the waters of the Evenlode are reinforced at this point in its course by the two contingent streams I described in the last chapter, so the main rail- 
way is here joined by two subsidiary lines, the one coming from Chipping Norton and the other from Cheltenham over the Cotswolds. Paradoxical as it may seem, I do not hesitate to say that this large mileage of railway within a small radius acts beneficially upon our bird-life. Let us see how this is.

In the first place, both cuttings and embankments, as soon as they are well overgrown with grass, afford secure and sunny nesting-places to a number of birds which build their nests on the ground. The Whin-chat for example, an abundant bird here every summer, gives the railway-banks its especial patronage. The predatory village-boys cannot prowl about these banks with impunity except on Sundays, and even then are very apt to miss a Whin-chat's nest. You may see the cock-bird sitting on the telegraph wires, singing his peaceful little song, but unless you disturb his wife from her beautiful blue eggs you are very unlikely to find them in the thickening grass of May or June. And even if she is on the nest, she will sit very close; I have seen an express train fly past without disturbing her, when 
I46 Midland Village: Railway and W'oodland.

the nest was but six or eight feet from the rails. The young, when reared, will often haunt the railway for the rest of the summer, undismayed by the rattle and vibration which must have shaken them even when they were still within the egg. Occasionally a Wheatear will make its appearance about the railway, but I have no evidence of its breeding there ; nor is the Stonechat often to be seen here, though it is a summer visitor not far off among the hills.

Let me say incidentally that no one who has either good eyes or a good glass ought ever to confound the two Chats together. In the breeding season the fine black head of the cock Stonechat distinguishes him at once; but even the female should never be the subject of a blunder, if the observer has been at all used to attend to the attitudes of birds. The Stone-chat sits upright and almost defiant, and is a shorter and stouter bird than the Whin-chat, which perches in an attitude of greater humility, and always seems to me to deprecate your interference rather than to defy it. And it is quite in keeping with this that the 'chat' of the latter is not so loud 
and resonant as that of the former, as I have satisfied myself after careful observation of both; the Stone-chat penetrating to my dull ears at a greater distance than his cousin. ${ }^{1}$ This really means that the bill of the one, and in fact his whole muscular system, is stronger than the same

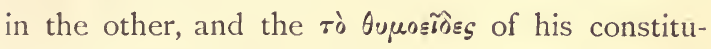
tion is more largely developed.

If I walk alongside of the railway, as it passes between the water-meadows and the corn-fields which lie above them, divided on each side from these by a low-lying withy-bed, I always keep an eye upon the telegraph-wires ahead, knowing by long experience that they will tell me what birds are breeding or have bred about here. As autumn approaches, great numbers indeed of visitors, Swallows, Martins, Linnets, and others, will come and sun themselves here, and even tempt a Sparrow-hawk or Kestrel to beat up and down the line; but in early summer, beside the Whin-chats, and the Whitethroats nesting in great numbers in the thick quickset hedges which

1 The chat of the Whin-chat is a dissyllable, 'u-tic'; that of the Stone-chat a monosyllable, 'chat.' (O. V. A.) 


\section{I48 Midland Village: Railway and Woodland.}

border the line, it is chiefly the melancholy tribe of Buntings that will attract my notice.

I trust my friends the Buntings will not take offence at being called melancholy; I cannot retract the word, except in what is now called "a parliamentary sense." I have just been looking through a series of plates and descriptions of all the Buntings of Europe, and in almost every one of them I see the same deflected tail and listless attitude, ${ }^{1}$ and read of the same monotonous and continually repeated note. The Buntings form in fact, though apt to be confused with one another owing to their very strong family likeness, perhaps the most clearly-marked and idiosyncratic genus among the whole range of our smaller birds. This may be very easily illustrated from our three common English species. Look at the common Corn Bunting, as he sits on the wires or the hedge-top; he is lumpy, loosefeathered, spiritless, and flies off with his legs hanging down, and without a trace of agility or

1 The Meadow Bunting (Emberiza cia) seemed to me, when I met with it in Switzerland this summer, to be more lively and restless than other Buntings. 
vivacity; he is a dull bird, and seems to know it. Even his voice is half-hearted; it reminds me often of an old man in our village who used to tell us that he had "a wheezing in his pipes." Near him sits a Yellow Bunting (Yellowhammer), a beautiful bird when in full adult plumage of yellow head, orange-brown back, white outer tailfeathers, and pink legs; yet even this valued old friend is apt to be untidy in the sit of his feathers, to perch in a melancholy brown study with deflected tail, and to utter the same old song all the spring and summer through. This song, however (if incleed it can be called one), is a much better one than that of the Corn Bunting, and is occasionally even a little varied. ${ }^{1}$

Just below, on an alder branch or withy-sapling, sits a fine cock Reed Bunting, whose jet-black head and white neck make him a conspicuous object in spite of the sparrow-like brown of his back and wings. Except in plumage, he is exactly like his relations. $\mathrm{He}$ will sit there, as long as you like to stay, and shuffling his feathers, give out his odd tentative and half-hearted song.

${ }^{1}$ See Note B at the end of the volume. 


\section{I50 Midland Village: Railway and Woodland.}

Like the others he builds on or close to the ground, in this case but a few yards from the rails, and his wife, like theirs, lays eggs streaked and lined in that curious way that is peculiar to Buntings alone. I have not had personal experience of our rarer Buntings, the Ortolan, the Snow Bunting, or even the Cirl Bunting, as living birds; but all the members of this curious race seem to have the characteristics mentioned above in a greater or less degree, and also a certain hard knob in the upper mandible of the bill, which is said to be used as a grindstone for the grain and seeds which are the food of them all in the adult state.

Keeping yet awhile to the railway, let us notice that even the station itself meets with some patronage from the birds. In the stacks of coal which are built up close to the siding, the Pied Wagtails occasionally make their nests, fitting them into some hospitable hole or crevice. These, like all other nests found in or about the station, are carefully protected by the employés of the company. In a deep hole in the masonry of the bridge which crosses the line a few yards 
below the station, a pair of Great Titmice built their nest two years ago, and successfully brought up their young, regardless of the puffing and rattling of the trains, for the hole was in the inside of the bridge, and only some six feet from the rails of the down line. A little coppice, remnant of a larger wood cut down to make room for the railway, still harbours immense numbers of birds; here for example I always hear the ringing note of the Lesser Whitethroat; and here, until a few years ago, a Nightingale rejoiced in the density of the overgrown underwood.

A Ring-ousel, the only specimen, alive or dead, which I have seen or heard of in these parts, was found dead here one morning some years ago, having come into collision with the telegraph wires in the course of its nocturnal migration. It was preserved and stuffed by the stationmaster, who showed it to me as a piebald Blackbird.

A little further down the line is another bridge, in which a Blue-tit found a hole for its nest last year; this also was in the inside of the bridge, 
$15^{2}$ Midland Village: Railway and Woodland.

and close to the up-line. This bridge is a good place from which to watch the Tree-pipit, and listen to its charming song. All down the line, wherever it passes a wood or a succession of tall elms and ashes, these little grayish-brown birds build their nest on or close to the grassy banks, and take their station on the trees or the telegraph-wires to watch, to sing, and to enjoy themselves. A favourite plan of theirs is to utter their bright canary-like song from the very top twig of an elm, then to rise in the air, higher and higher, keeping up their energies by a quick succession of sweet shrill notes, till they begin to descend in a beautiful curve, the legs hanging down, the tail expanded and inclined upwards, and the notes getting quicker and quicker as they near the telegraph-wires or the next tree-top. When they reach the perching-place, it ceases altogether. So far as I have noticed, the one part of the song is given when the bird is on the tree, the other when it is on the wing. The perching-song, if I may call it so, is possessed by no other kind of Pipit; but the notes uttered on the wing are much the same with all the species. 
The young student of birds may do well to concentrate his attention for awhile on the Pipits, and on their near relations, the Larks and the Wagtails. These three seemed to form a clearlydefined group; and though in the latest scientific classification the Larks have been removed to some distance from the other two (which form a single family of Motacillidae), it must be borne in mind that this is in consequence only of a single though remarkable point of difference. Apart from definite structural characters, a very little observation will show that their habits are in most respects alike. They all place their nests on the ground; and they all walk, instead of hopping; the Larks and the Pipits sing in the air, while the Pipits and the Wagtails move their tails up and down in a peculiar manner. All are earth-loving birds, except the Tree-pipit and the Woodlark.

We may now leave the railway, and enter the woodland. Most of the birds that dwell here have been already mentioned; and I shall only mention in passing the Jays, the Magpies, and the Crows, those mischievous and predatory birds, 


\section{I54 Midland Village: Railway and Woodland.}

which probably do more harm to the game in a single week of April or May, than the beautiful mice-eating Kestrel does during the whole year. They all rob the nests of the pheasants and partridges, both of eggs and young; and when I saw one day in the wood the bodies of some twenty robbers hung up on a branch, all belonging to these three species, I could not but feel that justice had been done, for it is not only game birds who are their victims. A large increase of these three species would probably have a serious result on the smaller winged population of a wood.

Among the more interesting inhabitants of the wood, there are two species which have not as yet been spoken of in these chapters-the Grasshopper Warbler and the Nightingale. The former has no right to be called a warbler, except in so far as it belongs to one of those three families mentioned in a former chapter, in which all our British 'warblers' are now included. It has no song, properly so called; but no one who has the luck to watch it alive, even without a detailed examination of its structure, will doubt its true 
relationship to the Sedge-warbler and the Reedwarbler. It is not a water-haunting bird, but still

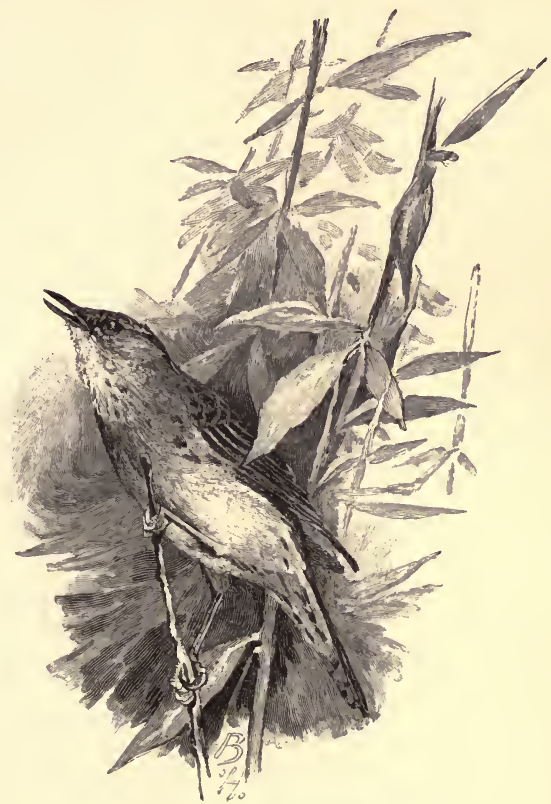

Grasshopper Warbler.

rather recalls the ways of its relations, by choosing deep ditches thickly grown with grass and reeds, 


\section{I56 Midland Village: Railway and Woodland.}

and sheltered by bramble-bushes; it seems to need something to climb up and down, and to creep about in; like the sedge-birds, it seldom flies any distance, and one is tempted to fancy that all these species would gradually lose the use of their wings as genuine organs of flight, if it were not for the yearly necessities of migration.

I once had a remarkable opportunity of watching this very curious bird. It was about the beginning of May, before the leaves had fully come out; a time which is very far the best in the year for observing the smaller and shyer birds. Intent on pairing or nest-building, they have little fear, if you keep quite quiet, and you can follow their movements with a glass without danger of losing sight of them in the foliage. I was returning from a delicious morning ramble through Bruerne wood, and was just rounding the last corner of it, where a small plantation of baby saplings was just beginning to put on leaf, when my ear caught the unmistakable 'reel' of this bird. Some other bircls of the warbler kind, Wren, Robin, Sedge- 
bird, can produce a noise like the winding-up of a watch, but none of these winds it up with such rapidity, or keeps it going so long as the Grasshopper Warbler, nor does any cricket or grasshopper perform the feat in exactly the same way. Our bird's noise-we cannot call it a voice-is like that of a very well-oiled fisherman's reel, ${ }^{1}$ made to run at a very rapid rate, and its local name of the 'reel-bird' is a perfectly just and good one.

I was on the outside of a little hedge, and the noise proceeded from the saplings on its further side. In order to see the bird I must get over the hedge, which could not be done without a scrunching and crackling of branches sufficient to frighten away a much less wary bird than this. There seemed, however, to be no other chance of getting a sight of the bird, so through the hedge I went ; and tumbled down on the other side with such a disturbance of the branches that I gave up all hope of attaining my object.

1 Or like a delicate electric bell, heard at some distance, while the door of your room is slowly opened and again closed. 


\section{I58 Midland Village: Railway and Woodland.}

Great was my astonishment when I saw only a few yards from me a little olive-brown bird creeping through the saplings, which I knew at once - to be the Grasshopper Warbler. I then took up a fixed position, the little bird after a minute or two proceeded to do the same, and for some time I watched it with my glass, as it sat on a twig and continued to utter its reel. It was only about ten paces from me, and the field-glass which I carried placed it before me as completely as if it had been in my hands. What struck me most about it was its long supple olive-green neck, which was thrust out and again contracted as the reel was being produced; this being possibly, as I fancy, the cause of the strange ventriloquistic power which the bird seems to possess; for even while I watched it, as the neck was turned from side to side, the noise seemed to be projected first in one direction and then in another. ${ }^{1}$ The reel was uttered at intervals, and as a general rule did not continue for more than a quarter of a minute,

1 Another cause is doubtless the crescendo and diminuendo which the bird uses: see a valuable note in The Birds of Cumberland, by the Rev. H. A. Macpherson and W. Duckworth. 
but one spell of it lasted for forty seconds by my watch. It is said to continue sometimes for as much as twenty minutes, but I have never been fortunate enough to hear it for anything approaching to that length of time.

Our interview was not to last very long. It unluckily happened that my little terrier, who accompanies me in all my walks, and is trained to come to heel when anything special is to be observed, had been out of sight when I broke the hedge; and now he must needs come poking and snuffing through the saplings just as if a Grasshopper Warbler were as fair game as a mole or a water rat. Nevertheless, so astonishing was the boldness of this bird that he allowed the dog to hunt about for some time around him without being in the least disconcerted. ${ }^{1}$ When at last he made off he retreated in excellent order, merely half flying, half creeping with his fan-like tail distended, until he disappeared in the thick underwood. I would have taken the dog under my

1 In May this year (1886) I nearly trod upon a pair of these birds, near the same wood: yet they showed no fear, allowed me to approach them within six paces, and continued to reel close at hand. 
i6o Midland Village: Railway and Woodland.

arm and tried for another interview, which no doubt he would have given me, if I had not been obliged to depart in order to catch a train to Oxford. This bird was undoubtedly a male who was awaiting the arrival of the females: just at this time they not only betray themselves more easily by the loudness of their reel, but also are well known to be less shy of showing themselves than at any other period of their stay with us. This is the case with most of our summer migrants. Only a few minutes before I found this bird, I had been watching a newly-arrived cock Nightingale, who had not yet found his mate, and was content to sing to me from the still leafless bough of an oak-tree, without any of the shyness he would have shown two or three weeks later.

We have every spring a few pairs of Nightingales in our woods. Except when a wood has been cleared of its undergrowth, they may always be found in the same places, and if the accustomed pair is missing in one it is almost sure to be found in another. The edge of a wood is the favourite place, because the bird constantly seeks 
its food in the open; also perhaps because the best places for the nest are often in the depth of an overgrown hedge, where the cover is thicker than inside a wood. Sitting on the sunny side of such a wood, I have often had ample opportunity of hearing and watching a pair : for though always somewhat shy, they are not frightened at a motionless figure, and will generally show themselves if you wait for them, on some prominent bough or bit of railing, or as they descend on the meadow in quest of food.

I am always surprised that writers on birds have so little to say of the beauty of the Nightingale's form and colouring. It is of the ideal size for a bird, neither too small to be noticed readily, nor so large as the somewhat awkwardly built Blackbird or Starling. All its parts are in exquisite proportion; its length of leg gives it a peculiarly sprightly mien, and tail and neck are formed to a perfect balance. Its plumage, as seen, not in an ornithologist's cabinet, but in the living and moving bird a little distance from you, is of three hues, all sober, but all possessing that reality of colour which is so sat sfying to the 
I62 Midland Village: Railway and Woodland.

eye on a sunny day. The uniform brown of the head, the wings, and the upper part of the back, is much like the brown of the Robin, a bird which in some other respects strangely resembles the Nightingale; but either it is a little brighter, or the larger surface gives it a richer tone. In both birds the brown is set off against a beautiful red; but this in the Nightingale is only distinct when it flies or jerks the tail, the upper feathers of which, as well as the longer quills, and especially the innermost ones, are of that deep but bright russet that one associates with an autumn morning. And throat and breast are white; not pure white, but of the gentle tone of a cloud where the gray begins to meet the sunshine.

In habit the Nightingale is peculiarly alert and quick, not restless in a petty way, like the fidgety Titmice or the lesser warblers, but putting a certain seriousness and intensity into all it does. Its activity is neither grotesque nor playful, but seems to arise from a kind of nervous zeal, which. is also characteristic of its song. If it perches for an instant on the gorse-bush beneath the hedgerow which borders the wood, it jerks its tail up, 
expands its wings, and is off in another moment. If it alights on the ground, it rears up head and neck like a thrush, hops a few paces, listens, darts upon some morsel of food, and does not dally with it. As it sings, its whole body vibrates, and the soft neck feathers ripple to the quivering $\mathrm{cf}$ the throat.

I need not attempt to describe that wonderful song, if song it is, and not rather an impassioned recitative. The poets are often sadly to seek about it ; Wordsworth at least seems to have caught its spirit :

"O Nightingale, thou surely art

A creature of a fiery heart."

And Wordsworth, as he tells us in the next stanza, found the cooing of the stock-dove more agreeable to his pensive mind. I never yet heard a Nightingale singing dolefully, as the poets will have it sing $;^{1}$ its varied phrases are all given out con brio, and even that marvellous crescendo on a single

1 As in Milton's "most musical, most melancholy." But as Coleridge remarks in a note to his own poem of the Nightingale, in Sibylline Leazes, these words of Milton are spoken in the character of the melancholy man, and have therefore a dramatic rather than a descriptive propriety. Coleridge's own conception of the song is the true one and most happily expressed. 
I64 Midland Village: Railway and Woodland.

note, which no other bird attempts, conveys to the mind of the listener the fiery intensity of the high-strung singer. It is a pity to compare the songs of birds; our best singers, Thrush, Blackbird, Blackcap, Robin, and Garden-warbler, all have a vocal beauty of their own; but it may safely be said that none approaches the Nightingale in fire and fervour of song, or in the combination of extraordinary power with variety of phrase. He seems to do what he pleases with his voice, yet never to play with it ; so earnest is he in every utterance-and these come at intervals, sometimes even a long silence making the performance still more mysterious-that if I were asked how to distinguish his song from the rest, I should be inclined to tell my questioner to wait by a wood side till he is fairly startled by a bird that puts his whole ardent soul into his song. But if he will have a description, let him go to old Pliny's tenth book, or rather to Philemon Holland's translation of it, which is much better reading than the original; and there he will find the most enthusiastic of the many futile attempts to describe the indescribable. 
The Nightingale's voice is heard no more after mid-June; and from this time onwards the woods begin to grow silent, especially after early morning. For a while the Blackcap breaks the stillness, and his soft sweet warble is in perfect keeping with the quiet solitude. But as the heat increases, the birds begin to feel, as man does, that the shade of a thick wood is more oppressive than the bright sunshine of the meadows; and on a hot afternoon in July you may walk through the woodland and hardly catch a single note.

But on the outskirts of a wood, or in a grassy 'ride,' you may meet with life again. The Titmice will come crooning around you, appearing suddenly, and vanishing you hardly know how or whither; Wood-pigeons will dash out of the trees with that curious impetuosity of theirs, as if they were suddenly sent for on most pressing business. A Robin will perch on a branch hard by, and startle you with that pathetic soliloquy which calls up instantly to your memory the damp mist and decaying leaves of last November. The Green Woodpecker may be there, laughing at you from an elm, or possibly (as I have sometimes seen him) 
r66 Midland Village: Railway and Woodland.

feeding on the ground, and looking like a gorgeous bird of the tropics.

Other birds of the Woodpecker kind are not common in our woods. The Greater Spotted Woodpecker has only once fairly shown himself to me; the Lesser Spotted Woodpecker, which I have heard country folk call the French Heckle, seldom catches the eye, ${ }^{1}$ though to judge by the number of stuffed specimens which adorn the parlours of inns and farm-houses, it can by no means be very rare. For this name 'heckle,' and all its curious local variants, I may refer the reader to Professor Skeat's most valuable etymological contribution to Newton's Edition of Yarrell's Birds; ${ }^{2}$ but why, one may ask, should it be called the French Heckle? A very old gamekeeper, who described to me by this name a bird which was certainly the Lesser Spotted Woodpecker, also used the expression English Heckle

1 A Woodpecker on a railway bridge is a curiosity. But a Lesser Spotted bird was once seen on the stonework of the bridge which spans the Chipping Norton branch line, by the Rev. S. D. Lockwood, Rector of my parish, who knows the bird well.

${ }^{2}$ Vol. ii. pp. 461-463. Hickwall seems to be the recognized orthography; but I spell the word as it was pronounced. 
for the Wryneck-a bird (he said) much plainer than the French Heckle, and apt to hiss at you if you try to take its eggs. I imagine that French is here contrasted with English to indicate superior brightness and dapperness of plumage.

There is yet one bird of our woods-or rather of one wood, thickly planted with oaks-of which I have as yet said nothing. I had long suspected his presence in that wood, but my search for him was always in vain. One day in May, 1888, I luckily turned down a little by-path which led me through a forest of young ashes, and brought me out into a wide clearing carpeted with blue-bells and overshadowed by tall oaks. Here I heard a sibilant noise, which in the distance I had taken for the Grasshopper Warbler; though I had had doubts of it, as it was not prolonged for more than two or three seconds. Now also I heard, from the thick wood beyond the clearing, a series of plaintive notes, something like those of the Tree Pipit, and this stopped me again as I was turning away. I listened, and heard these notes repeated several times, feeling more and more certain each time that I had heard them before in 
I68 Midland Village: Railway and Woodland.

this very wood, and suspected them to be the call-notes of the Wood-warbler, a bird with which, strangely enough, I had never had any personal acquaintance.

The sibilant noise was all this time going on close at hand. The wood was comparatively silent owing to the east wind, and I could concentrate my attention on these new voices without distraction. I noticed that the sibilation was preceded by three or four slightly longer and more distinct notes, and as this answered to my bookknowledge of the Wood-warbler, I became more and more anxious to see the bird. But he would not let me see him. And then came the puzzling plaintive notes again, as different as possible from the sibilant ones, and it became absolutely necessary to discover whether they were uttered by the same creature.

At last I throught I had made sure of the bird in one particular little thicket not more than ten or twelve yards from me, and crept on as softly as possible out of the clearing into the underwood. Of course the dead twigs crackled under my feet and the branches had to be put forcibly aside, and 
the voice retreated as I neared it. I thought of a certain morning in the Alps, and of a provoking and futile hunt after Bonelli's Warbler; but pushing on a little further into a small open space, I stopped once more, and then firmly resolved not to move again.

I had a long time to wait. Sometimes the plaintive voice, but oftener the sibilant notes, would be uttered quite close to me, and the singer would stay for some time in the same bush, hidden from my sight, but near at hand. And at last, as a fisherman sees the surface of the smooth black pool in an instant broken, and then feels his fish, I caught sight of a momentary motion in the leaves not ten yards away from me. A minute later I saw the bird, and knew at once that I had the Wood-warbler before me. There was nothing now to do but to stand motionless and see more of it.

By degrees it seemed to grow used to my presence, and showed itself to me without any sign of alarm. What can be more delightful than to watch in perfect solitude and security the bird you have been looking for so long? There was the yellow throat, the delicate white breast, the 


\section{roo Midland Village: Railway and Woodland.}

characteristic streak over the eye-all plainly visible as he sat facing me; and when he kindly turned his tail to me and preened his feathers, I could see the greenish-brown back, and note the unusual length of wing. Several times, when close to me, he gave utterance to that curious 'shivering' sibilation (to use Gilbert White's apt word), his bill opening wide to give the last shake, his head lifted upwards, the long wings quivering slightly, and the whole body vibrating under the effort. One thing more was needed - a visible proof that the long-drawn plaintive notes were his notes too, and this I had the pleasure of securing by a little more patience. But when my little warbler uttered these notes, his bill was not opened wide, nor did his frame vibrate with any apparent effort; they seemed rather an inward soliloquy or a secret signal (as indeed they were), and always ended up with a short note and a sudden closing of the bill, as if to say, "All's right, that's well over."

Then behind me I heard the undoubted double call-note of a warbler, which probably I myself caused the little bird's wife to utter, trespassing 
as I surely was in the neighbourhood of the nest. It did just cross my mind that I ought to search for that nest,' but I gave up the iclea almost at once, and bade adieu in peace to my new friends. They had shown themselves to me without fear, and they should have no reason to dislike me.

Beyond the woods where these birds live, we come out on scrubby fields, often full of thistles, and spotted with furże-bushes. These fields are the special favourites of the Linnets and Goldfinches; the Linnets are in great abundance, the latter, since the Wild Birds' Act came into operation, by no means uncommon in autumn.

We cannot but pause again and again as we make our way through the gorse and brushwood, for the little Linnet in his full summer dress is hardly less beautiful than the Goldfinch, and all his ways and actions are no less cheering and attractive. The male birds differ much, perhaps according to age, in brilliancy of plumage; but a fine cock Linnet in full dress of crimson breast' and crown, white wing-bars and tail-feathers, and chestnut back, is to my thinking as splendid a little bird as these islands can show. I can never 
172 Midland Village: Railway and Woodland.

forget the astonishment of a companion who hardly knew the bird, when I pointed him out a Linnet in this splendid costume one July day on a Radnorshire hill.

The ground now rises towards the hills which form the limit of our western horizon. On these hills may now and then be seen a few birds which we seldom meet with in the lower grounds, such as the Stone-chat, the Brambling, the Wheatear; but as the hills are for the most part cultivated, and abound in woods and brooks, the difference between the bird life of the uplands and the lowlands is not remarkable at any time of the year.

It may be worth while, however, to note down in outline the chief movements of the birds in our district in the course of a single year. In January, which is usually the coldest month in the year, the greater number of our birds are collected in flocks in the open country, the villages only retaining the ordinary Blackbirds, Thrushes, Robins, \&c. The winter migrants are in great numbers in the fields, but they and almost all other birds will come into villages and even into towns in very severe weather. In February, 
villages, orchards, and gardens are beginning to receive more of the bird population, while the great flocks are beginning to break up under the influence of the approach of spring. In March the same process goes on more rapidly; the fields are becoming deserted and the gardens fuller. But meanwhile hedges, woods, thickets and streams are filling with a population from beyond the seas, some part of which penetrates even into the gardens, sharing the fruit-trees with the residents, or modestly building their nests on the ground. As a rule, though one of a very general kind, it may be laid down that our resident birds prefer the neighbourhood of mankind for nesting purposes, while the summer migrants build chiefly in the thickets and hedges of the open country; so that just at the time when Chaffinches, Greenfinches, Goldfinches, and a host of other birds are leaving the open country for the precincts of the village, their places are being taken by the new arrivals of the spring. Or if this rule be too imperfect to be worth calling a rule at all (for all the Swallow kind but one British species build in human habitations), it is at least true that if a 


\section{I74 Midland Village: Railway and Woodland.}

garden offers ample security for nesting, the proportion of residents to migrants taking advantage of it will be much greater than in a wood or on a heath.

Just as the population of the open country begins to decrease in numbers in early spring, so it increases rapidly in the first weeks of summer. The young broods that have spent their infancy in or near the village now seek more extended space and richer supplies of food, and when the hay is cut, they may be found swarming in all adjacent hedges and on the prostrate swathes, while the gardens are comparatively empty. But before July is over an attentive watcher will find that his garden is visited by birds which were not born and bred there; while the residents are away in the fields, the migrants begin to be attracted to the gardens by the ripening fruits of all kinds. White-throats, Willow-warblers, Chiff-chaffs, haunt the kitchen-garden for a while, then leave it on their departure for the coast and their journey southwards. After this last little migration, the villages and gardens remain almost deserted except by the Blackbirds and Thrushes, 
the Robins and the Wrens, until the winter drives the wilder birds to seek the neighbourhood of man once more. Even then, unless the garden be well timbered, they will be limited to a very

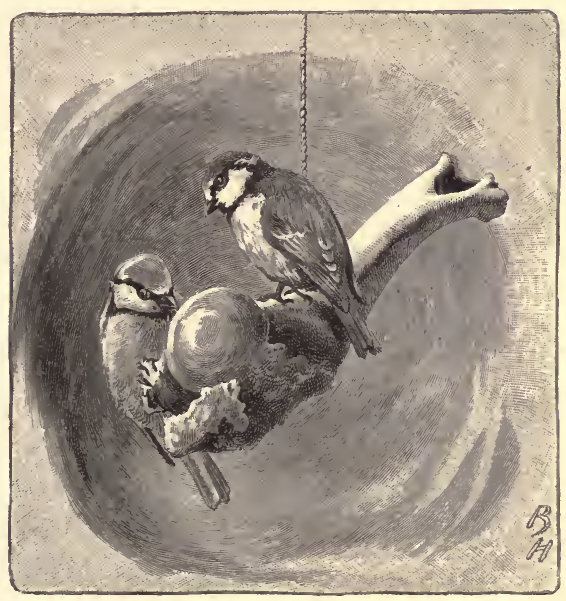

Out-door relief.

few species, except in the hardest weather; and it is remarkable how little variety will be found among our winter pensioners-those recipients of out-door relief, who spoil their digestions by 
176 Midland Village: Railway and Woodland.

becoming greedy over a food which is not natural to them.

This rough attempt to sketch the local migrations of birds must be understood as applying to my own village only, and to gardens which are not surrounded with extensive parks. 


\section{CHAPTER VI.}

THE ALPS IN SEPTEMBER.

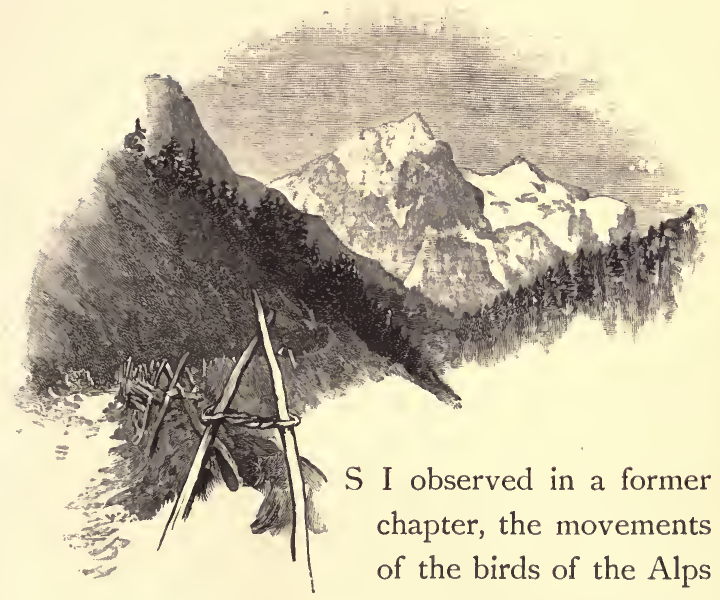
are, or ought to be, of very great interest to the ornithologist, owing partly to the wonderful variety of food and climate afforded by the gigantic 
structure of this mountain district, and partly to its geographical position, lying as it does in the very centre of the various routes of migration in spring and autumn.

I had long been anxious to obtain some more reliable information about these movements than I had acquired when my third chapter was written, and to obtain it as far as possible at first hand; and I eagerly seized the opportunity, in September of the present year ( 1886 ), of a visit to relations in Germany, to make a rapid detour to the Alps, about the time when the more delicate birds would be beginning to leave the higher valleys and pastures, now fast becoming too cold at night to suit their tender frames. I was able to remain only a very few days, but I saw and heard enough to occupy my attention fully during that short time, and am disposed to hope that by setting down my experiences I may attract the attention of autumn travellers to a matter which lends new interest to a hackneyed region, after the flowers have disappeared, and when the days are getting too short for ambitious mountain-climbing.

I arrived at Lucerne on the morning of 
September i6, and went on at once to Alpnacht, at the extreme end of the south-western arm of the lake, having on my left the starting-point of our former walk. I did not expect to see anything of autumn migration quite so early as this, or I should have taken the St. Gotthard line direct to the great tunnel, and then have established myself at once at or near the head of the Reuss valley which the railway follows; but I wished to see what birds were still to be found in the lower levels, and determined to spend a day or two in the great valley of Hasli, where I left my reader at the end of my third chapter. Before I take him further on this second round of exploration, I must ask him to look with me at a map of Switzerland, in order that we may understand the geographical conditions of the problem about which I was now going to try and learn a little.

A little study of a good map will show that the true alpine region of Switzerland proper consists of two enormous mountain barriers, fencing in, to north and south, a deep trench, nearly a hundred miles in length. This trench represents the 
valleys of the Rhine and Rhone, which start within a short distance of each other, and are only interrupted for a few miles, in the very centre of the region, by the upper part of the valley of the river Reuss, which here forms a kind of elevated plain, enclosed, like the trench itself, between vast mountains; this plain is the bed of an ancient lake, which once escaped from its prison through a narrow opening at the eastern end, where the Devils' Bridge now stands. On the northern side of the trench, throughout its whole length, the mountain barrier is pierced by ordinary summer routes at three points only: beginning from the west, at the Gemmi Pass, north of the Rhone, where the opening is artificial rather than natural; at the Grimsel Pass, which debouches upon the source of the Rhone in its Glacier; and at the point mentioned just now, where the lake made its escape, and where a tunnel driven through the rock has taken the place of an ancient hanging bridge. Nothing can be more striking to a geographical eye than the fact that from the point where it abuts upon the lake of Geneva (where communication is of course 
easier) to the point where the Rhine curves round to the north at Chur, the northern barrier of the trench offers only these three passages to the ordinary human traveller. The southern rampart, though for the most part broader, and including the highest European peaks, admits the traveller southward at several points, and is pierced by two excellent carriage roads, those of the Simplon and the St. Gotthard.

During the summer, the parts of Switzerland north of the trench and its two barriers, are occupied by countless fragile birds, which have come from Africa over Italy, and must return there in the autumn. How do they come, and how do they return? Of their arrival I have had no personal experience, and shall therefore say nothing; for it does not follow that birds always come and go in exactly the same manner and by exactly the same route. But of the departure of some of them I can now tell something, having had the evidence of my own eyes that a double barrier such as I have described is not a fatal obstacle to their progress. 'The main facts of the migration have indeed been long known, and only 
too well known, to the inhabitants of the district; for the people of Canton Tessin, which consists of the valleys to the south of the central part of the Alps, sharing the tastes of their neighbours the Italians, were until a few years ago in the habit of lying in wait for the birds, and snaring them in vast numbers. When the hold of the Central Federal Government over the individual Cantons was made stronger a few years ago, the same absolute prohibition of wanton slaughter was extended to this canton, which had long been respected in the others; and in spite of a cantonal appeal to be allowed to revert to the old licence, the "Bund" held its own, and succeeded in protecting the migrants. No bird may now be killed at any time of the year in any part of Switzerland, without either a game licence, of which the cost is considerable, or a permission to procure specimens for a scientific object.

We took no gun with us on this occasion, being more anxious to observe movements than to identify species. My plan was, after noting the bird-population of the lower levels, which we called Region No. I, to pass through the northern 
barrier by the Grimsel or the St. Gotthard, and take my station at the head of one of these passes, in the highest ground of the great trench, and there to look about me, and also to make inquiries about the 'Vögelzug.' Accordingly, after leaving the lake of Lucerne, I turned in the direction of the great valley of the Aar, or Haslithal, which leads up to the Grimsel Pass, knowing that at Meiringen, which lies in the flat of it, not far from its issue into the lake of Brienz, I should be able to see almost in a single walk what summer migrants were still to be found in it. But I halted for the night at the beautiful village of Lungern, in order to enjoy the walk over to the Haslithal in the early morning of the next day; and here I was met by my old friend Anderegg, who was as eager as myself for a week of diligent observation.

The next morning was one of those which seem to stir the hearts of all living creatures, urging them to the enjoyment of autumn warmth while it lasts, and to the pursuit of food while it is still abundant. We had hardly entered the first pinewood when Anderegg detected the querulous 
sibilation of the Crested Tit, and two minutes later we had a little family around us, searching the fir-branches without showing any anxiety at our presence. Shortly afterwards a pair of Ravens passed over us, twisting themselves round as they flew through the morning mist, in a peculiar way, and without any object as far as I could see; and at the same moment a small party of Crossbills on the very top of a pine began to chatter with indignation at the appearance of a possible enemy. A few minutes later my sharp-eared companion heard the voices of the Great Black Woodpecker and of the Greater Spotted Woodpecker (Schildspecht); but the forest was here so large and dense that we were obliged to move on without seeing either. Passing slowly upwards, and enlivened by the close neighbourhood of Jays, Nutcrackers, Missel-thrushes, and by the occasional song of both Robin and Wren, we arrived near the highest point of the Brünig carriage-road, where it runs for some distance almost at a level, and is carried along the side of a steep ascent, the hollow below it being covered with undergrowth stretching down to sunny meadows, while 
the pine-forest rises above it sharp and dense. A better position for an ornithologist could hardly be desired; for as he stands at the edge of the road his eye must catch every movement in the bushes below him, while his ear commands for a considerable distance the pine-wood above him. Here I walked up and down for some time, scanning the multitudinous Cole-tits and Marshtits which were playing in the cover below the road, and mentally comparing their plumage with that of our British forms of the same species ; and while thus occupied, a Great Black Woodpecker, the first I had ever seen alive, hove in sight and fixed himself on a pine at no great distance, enabling me to watch him for some time with my strongest glass, as he went to work on the bark, now and again twisting his head round watchfully, like a Wryneck, and giving me an excellent view of his powerful bill. Presently, with rapid wingstrokes, like those of the Green Woodpecker, he flew over our heads, and was lost in the forest above us. As he flies, he utters a series of laughing notes, and often gives out a prolonged call after settling on a tree. $\mathrm{He}$ is a very fine and 
remarkable bird; as large, said Anderegg, as a fowl, using precisely the same comparison which occurred to Aristotle two thousand years ago.

We then descended rapidly into the Haslithal, where I spent one wholc day in noting such of its feathered inhabitants as had not already deserted it, or were likely to stay in it during the winter. The most remarkable feature of this broad and flat hollow in the hills, is the river Aar, which has been artificially confined for several miles within a strong stone embankment. On this particular day the stonework on each side was literally alive with Wagtails; the left bank seemed almost exclusively occupied by the gray species, and the right bank by the white. All these were continually flying out over the swift glacier water, hovering for a few moments as they sought for flies, and then retiring to their station on the bank; and this was going on for the length of a full mile between the two bridges, so that the whole number of Wagtails must have been enormous. I could hardly avoid the conclusion that these birds had collected in view of migration. The Gray Wagtail, Anderegg tells me, is never to be seen here 
in the winter, and the white species seldom; but as to what becomes of them I am unable as yet to be sure. Perhaps they simply move down the river into the lower and warmer districts of western and northern Switzerland; just as in England also there is a general movement of Wagtails in the autumn from the more mountainous districts into the regions of plain and meadow.

Another unusual sight was the vast assembly of Carrion Crows, which gathered in the evening, first to drink (not in the rushing Aar, but in a stream quiet enough to give me a momentary view of a Kingfisher); then to perch on a number of small fruit-trees, and finally to wheel round and round among the pines and precipices, until they settled down to roost for the night. But for their voices and their black bills, it was hard to believe that they were not rooks; but no rook was visible, and this bird seems almost unknown in the valley. After seeing this strange sight, I find it hard to assent to the universally accepted proposition, that the Crow is never, strictly speaking, a gregarious bird. So constant is their habit here of roosting together, that Anderegg told me that he had more 
than once, when out hunting at night, been almost deafened with the noise they made when threatened by the gigantic Eagle-owl.

Of the ordinary summer birds there were few to be seen, though the weather was warm for September. The Chiff-chaff sang now and then from the hotel garden, and a certain number of Willowwarblers were still about the beans and flax in the fields; Bonelli's Warbler (see p. I09) I was quite unable to detect. There were a few Swallows, House-martins, and Crag-martins ; Goldfinches in fair abundance, very busy with seeds in the cultivated land; a few Robins, and a solitary Whinchat. " I began to fear that I had come too late to witness any considerable migration; for even the Black Redstart, the representative bird of these valleys in summer, was in much smaller numbers than usual. Even the Starlings had all departed to a bird, not to return till March. On the other hand, the birds of the higher regions were already showing a disposition to come down to lower levels ; among these the most interesting were the Nutcrackers (often in company with Jays) and the Crossbills. These last-mentioned birds, 



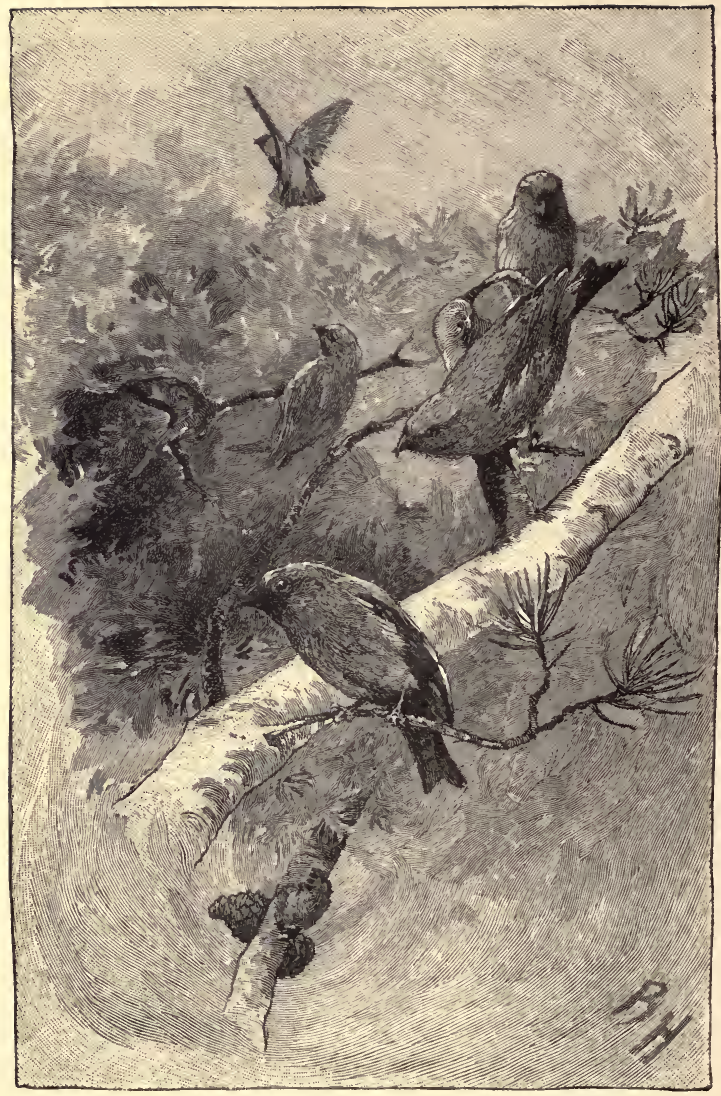

Crossbills on top of pine.-p. 189 
which are so seldom to be seen in England, were now to be found in the lowest instead of the highest pinewoods, in pairs or in small companies, giving warning of their presence by a rapidly repeated alarm-note. Generally they were on the very top twigs of a pine, where it was difficult to obtain a good sight of them; but one morning Anderegg's son, who is beginning to pick up his father's powers of observation, detected a pair on a pine below us, which both his elders had passed by unheeding. They were breakfasting each on the seeds of a cone, and I was able to observe with the glass how admirably the crossed mandibles are adapted for cutting into the heart of the fruit. The plumage of the male was a sober red, less brilliant than it will be next spring; and the female's dull greenish colouring was hardly recognizable against the pines. The presence of these birds close down to the valleys denoted the rapid approach of a cold season, and it became plain that if I were to catch the southward migrants I must hasten upwards towards St. Gotthard. This I determined to do by the shortest possible route, crossing the Susten Pass eastwards into the 
Reuss valley at Wasen, and so getting easily to the highest point of the great trench.

The Alps have a beauty of their own in September, even when there are few flowers left, and the snow has long disappeared in all the highest pastures. This is the time when the second crop of grass is cut; and the mowing leaves a short and beautiful mossy golden turf, which shines brightly in the sun, and lies softly and smoothly where a pine or a boulder casts its shadow on the ground. The walk through the Gadmenthal up to the Susten Pass was one to be remembered for beauty, though not ornithologically productive. The only curiosity that I saw was a Creeper running up a house; a very natural proceeding on the part of the bird, where the houses are of wood, containing abundance of insects in the crannies. $^{1}$ The great curiosity of the valley, the

1 They will often build their nests in holes in the timber of the houses. Anderegg tells me that this was the case in his own house two years ago. Nor is this the only instance of the habits of birds being affected by the nature of the housearchitecture in these parts; for the House-martins, being unable (I suppose) to make their nests adhere securely against timber, or disliking the large projecting eaves, build in the Haslithal 
three-toed Woodpecker, whose 'fatherland' (as Anderegg called it) is among the highest pinewoods at the head of the valley, would not show himself; though in the village of Gadmen we were told by an inhabitant that he had lately seen no less than seven of this species-a whole family, I suppose-on a single tree. Perhaps they too had come downwards in expectation of the winter. Alpine autumn was indeed around us, and at Gadmen we saw the first signs of the general migration of man, beast, and bird, which takes place at this time of year. A flock of sheep, which had been all the summer on the elevated Wendenalp, had just come down, and was being penned in front of the inn as we arrived. Great part of the population of the valley had assembled to claim their own, and when the penning was done all plunged into the living mass, men, women, boys, and sheep being mixed up in one confused struggle. Anxiety sat upon their faces, for no under ledges of rock, and are known there as the Rock-martin, as distinct from the Rock-swallow (Felsenschwalbe), which is the name there given to the Crag-martin. It is well-known that there are places even in England where this bird prefers rocks to houses. 
man knows whether he shall find his own sheep; some wander away and are lost, and some few-a fact of interest to me-are not too big to be carried off by the Golden Eagles that dwell in the vast precipices of the Titlis above the valley.

Above Gadmen the valley rapidly narrows, soon becoming little more than a cleft in the mountains, until it opens out into a pleasant little basin of uneven rocky pasture, much of which has been eaten away by a great mass of glacier which has descended into it within the present century, and is now again rapidly retreating. In this little basin-the Stein-alp, as it is appropriately calledis an excellent little inn; and here is the very place to catch the migrants of the Hasli and Gadmen valleys, if they should be passing this way; for the narrowing of the glen below must bring them all into this little basin, before they rise to the final ascent immediately above the inn. On the morning of September I7, as I was greeting Anderegg, and suggesting to him that we should make a second attempt to find the rare Woodpecker, he informed me with animation that he had seen, first a large collection of small Finches 
flying overhead, and secondly, a great number of Pipits assembled on the Alp a few minutes' walk from the house. IVe at once went to look for these, but they had all disappeared; and we continued our walk downwards in search of the Woodpecker. But we had not gone far when our attention was attracted by a flock of Redstarts, working slowly upwards a little above the path; and turning back again, we followed these for some distance, assuring ourselves that they were no accidental assembly, but must be on their way to the head of the pass, and so onwards to the line of St. Gotthard into Italy. As we arrived again at the inn, we saw the flock of little birds which Anderegg had described in the morning; they were still about the inn, but so restless and so playful that even with a strong glass I could not be certain of their species. My own impression was that they were Redpolls ; Anderegg, however, positively asserted that he had caught the voice of Citril and Serin Finches.

I now proposed that we should mount to the top of the pass, in order to observe whether the birds we had noticed in flocks lower down were 
still making way upwards. The result of this movement was that we found the Pipits-all Alpine-pipits (see p. 93), as far as I could ascertain -in a sunny hollow just above the glacier; they were there in great numbers, but did not mount further so long as we remained. The Redstarts too we found still slowly working upwards on the same side of the valley on which we had seen them in the morning; they were now just opposite to the glacier. But on the top of the pass, where it was too cold to stay long, we saw no signs of migrants; it was occupied only by a few Alpine Accentors, while high above, at a height of full 9000 feet above the sea, the Alpine Choughs were enjoying the sunshine. As we were descending, I caught sight of a tiny little tarn on the opposite side of the glacier, on the rocky alp high up above the inn, which struck me as a likely place for birds, especially as it was sheltered by a little crest of stunted trees of some kind. Here, after the mid-day meal, we made our way, and finding nothing at all, lay down on the grass to enjoy a splendid view of the craggy defile below us. But we had not been lying long before a twittering was 
heard, and the little flock which had puzzled us in the morning came dancing overhead, and settled so deep in the stunted pines I had noticed from the top of the pass, that though we could see the movements of the branches, we could not once get a clear sight of a single individual. This was too provoking, and I at once proceeded to srawl slowly towards the bushes, getting round to the flank of the birds on a rising bit of ground, until I was within a few yards of them. All that I saw were Redpolls, ${ }^{1}$ and all of the 'Mealy' form known to ornithologists; the autumn moult had left them very white on breast and belly, and very mealy on wings and back. They were, as far as I could judge, a little larger than our British Lesser Redpoll. Were they too migrating, or were they going to spend the winter in the Gadmenthal? I suspect that they stay all their lives in the Alps, and instead of moving southward to a warmer climate when under stress of weather, have but to make a short journey to a lower station in

1 I afterwards saw three of the same species about some stunted thistles on the Furka-pass, at a height of 8000 feet, and on a bitter cold day. See Note I). at end of Volume. 
the valley, to find at once a warmer temperature and abundance of the food they scek.

The next day, September 20, we packed up our baggage, and left this health-giving spot with its iced air and scented breezes, and again climbed the pass on our way to Wasen, being anxious to get to the head of the St. Gotthard before the fine weather should desert us. I was not unwilling to see my fellow-creatures again, as I had been quite alone on the Stein-alp, except for a single hour which an Englishman of education and intelligence had made very enjoyable as he took his 'Mitta. gessen' and smoked his cigarette with me As it happened, we left just in time to enable us, as the reader will learn shortly, to see things worth recording at Hospenthal the following day.

On going up the ascent from the inn, I noticed that the Pipits were now in great numbers at $a$ lower level than yesterday, and this suggested the conclusion that a fresh instalment had arrived from below, while those of yesterday had gone still higher or descended on the other side. This idea was fully confirmed by what I saw afterwards; for a good many more were at or about the top, and 
as we sat there for a few minutes, one flew right over us and disappeared in the depths of the valley in the direction of Wasen. All the way down too on the other side little parties were making their way in the same direction; and thus it became clear that these birds at least do not take flight all at once, but move in a continuous stream of parties smaller or greater, much as the late Mr. A. E. Knox described the migration of the Pied Wagtails from west to east in the south coast of England, in his admirable Ornithological Rambles in Sussex. ${ }^{1}$ But we may well ask the question, Do they arrive in the same manner? The Susten Pass is 7000 feet above the sea, and is covered with snow from October to June. I myself once crossed it on June 29, when its deep snow bore no trace of human footsteps, and it was possible to make glissades over slopes where now not a vestige of snow was to be seen. Are we to suppose that the Pipits and their friends pass it in spring in spite of the snow, and travel in the

1 It is worth noting that Knox observed that the progress of the Pied Wagtail is chiefly observable between daybreak and ro a.m. All the movements. I noticed in the Alps were observed during the carlier morning hours. 
same gradual manner? I cannot yet answer this question, nor is it likely that I shall ever be able to witness the arrival of the Susten Pipits as I witnessed their departure; but I contrived in the course of a week in these regions to set a few intelligent natives in an inquiring mood with regard to these matters, and it is possible that next spring may bring me some scraps of useful information. At present I am content to remember that Mr. Knox, in the passage just now referred to, was the first to discover that the arrival and departure of our English species arc not performed in exactly the same manner.

We saw nothing of special ornithological interest in the melancholy Meienthal, which leads down from the Susten to the St. Gotthard railway at Wasen; but I was reminded of a passage in my third chapter (p. 83) when we arrived at the first considerable pasture, and found a whole community of men, women, children, cows, and goats, on the very point of migrating from their cool and healthy summer home. The cows were all gathered in front of the 'Sennhütten,' and when doors and windows had been made fast for the winter, all the 
human migrants stood for a few minutes in prayer, doubtless thanking God for the provision He had made for them and their cattle, and asking for a blessing on the pasture for the summers yet to come. Then all these Catholics of Uri streamed downwards with their cows in long procession, the head 'Senner' walking in front followed by one fine animal; and to-day the pasture is as still and desolate as it will be all the coming winter. Even the very stream that washes it will be less voiceful, when the first frosts have bound once more the snow that feeds and fills it through all the warm season. It was indeed most curious and interesting to find man, beast, and bird all leaving it on the same day.

On arriving at Wasen, being still alarmed lest I should be too late to see much on this side of the great double barrier - for it now became evident that the birds were taking advantage of the last fine weather-I had half a mind to go through the tunnel to Airolo, and catch them on the southern side. My second thoughts, however, were in this expedition unusually lucky, and I fortunately decided to stay for a night or two at 
Hospenthal, which lies just at the northern mouth of the St. Gotthard Pass proper, in that curious elevated valley mentioned at the beginning of this chapter, which lies just between the two halves of the great trench formed by the valleys of the Rhine and Rhone. Any birds crossing the St. Gotthard into Italy must necessarily pass Hospenthal, and I had heard enough already of migration in this district to make me pretty confident of getting information here, even if I were not lucky enough to see anything myself.

When 'we issued from the 'Urner-loch' into this broad and grassy valley, it was just beginning to grow dark; but we could see great numbers of swallows and martins on the church steeples both. of Andermatt and Hospenthal, which are about a mile apart. As I came down the next morning at 7 a.m., I was met by Anderegg, who informed me that the gathering on the Hospenthal steeple had left their station in a body at 6 a.m., had circled high into the air for a few minutes, and then taken a directly southward course, not by the St. Gotthard road, but over the shoulder of the mountain which separates that road from a 
parallel valley to the east of it. That this account was true I was able to prove to my own satisfaction, for on the morning of the next day I was up in time to see a new party depart in precisely the same manner and the same direction. Like the Pipits, these Swallows and Martins migrate in considerable flocks coming one behind the other ; and so far as we could ascertain from walks taken during the day, these flocks occupy successively the steeples of Andermatt and Hospenthal, coming up from the lower valley and settling first on the former, then leaving it when the other is free, and so eventually leaving that also to rise for their last flight over the great barrier. How long this process goes on I could not very clearly ascertain. But there were still young martins in the nests at Hospenthal, which would hardly be ready to fly for some days, and as we subsequently found a certain number of martins (though very few swallows) when we returned to the Haslithal, I am inclined to think that it occupies a considerable time, and differs in length according to the weather. On the occasion of my visit, though it was fine and warm, 
the barometer was falling, and the very next day a continuous rain and snow-fall set in, lasting nearly three days; so that it seemed as if the birds were making haste to escape from a climate which might very well be dangerous to them. In Meiringen I was told that great numbers of them were caught and killed by severe weather in September last year. And the waiter in the hotel at Hospenthal, who most fortunately has some interest in these matters, and keeps his eyes open in his idle autumn hours, declared that he had seen the martins so eager to induce their young to leave the nest before it was too late, that at last they pulled them out by main force and compelled them to join the general assembly on the steeple.

This same man had also noticed a migration of another kind, which it may be worth while to record here. Sitting in front of the hotel, with nothing to do, he had observed a constant stream of dragon-fies making their way up the valley; and during my walks that day I was able fully to verify his statement. All the way from Hospenthal to Andermatt these creatures were to be 
seen coming up against the wind, which was now blowing from the west. Doubtless I should never have noticed them, if my attention had not been drawn to them by this most fortunately situated observer. There was no mistake about it ; countless numbers were steadily passing up the valley, but whither they were going it was hopeless to ascertain; they did not seem to turn up the St. Gotthard road, for I remarked them the whole way up the valley to the foot of the Furka Pass westwards. Frau Meyer, landlady of the hotel, told me that she had once witnessed an extraordinary flight of countless butterflies at Hospenthal; but could not tell me the species. I had myself previously noticed the tendency of the Apollo butterfly at the Stein-alp to fly up the pass-every individual I saw being apparently on his way upwards. And this was against an cast wind, close to a glacier, and on the Igth of September!

The migrating birds, however, did not seem to get any further up the valley than Hospenthal; and indeed at no point further up would they have found a route into Italy so comparatively free from 
difficulty. We took a walk in the afternoon in order to ascertain whether this were so, and the result was interesting. Let it be understood that at Hospenthal the St. Gotthard road turns sharp to the south up a narrow valley, while the elevated valley or plain in which Hospenthal lies extends for several miles further to the foot of the Furka Pass, which leads, not into Italy, but into the Rhone valley westwards. Exactly as the human traveller into Italy follows the road up the narrow defile, leaving the broad plain behind him, so do the birds change their direction at this point, and prepare to leave food and comfort until they are on the southern side of the barrier. All day long a little tract of broken ground lying between the hotel and the river had been alive with Pipits; but when we walked further up the main valley westwards not a bird was to be seen, except here and there a lingering Redstart. The desolation was complete; yet no sooner had we returned to Hospenthal, than we were greeted again by Pipits, Wagtails, Martins, and even by a solitary Wheatear, who seemed left behind by his relations. This was the only bird of its kind which I saw 
during my stay in the Alps. The Wheatears are, as in England, the first migrants which arrive in the spring, and doubtless they are also among the first to depart. The only other bird which was common here at this time was the Kestrel-the Thurmfalk (tower-falcon) as he is here called; they nest in the Alps in old towers or rocks, and several were always to be seen about the old Lombard tower which overlooks the village, and once overawed its inhabitants.

The next day I resolved to try whether the Grimsel Pass, the second principal opening from the north through the great barrier, would show us anything new; but in this project I was disappointed, for rain and intense cold came on, which drove me down to Meiringen and deprived me of any opportunity of further observation. And here, as I write, the sun has once more broken through the clouds, a bracing north wind blows, the mountains above us are covered with fresh snow, the trees are beginning to lose their summer green, the cow-bells are ringing in the valley instead of upon the alps, and alpine autumn is here in all its health and beauty. The hotel is 
empty, and my only companions are the faithful Anderegg and my host, Herr IVilli, now Cabinet Minister of his Canton, who entertains me with discourse of the history of the Haslithal, the antiquities of which he has been the first to explore. Some summer birds are still here; the Chiffchaff for a single moment uttered its voice outside the window by which I write. The Robins are in fair abundance, and a few will stay in the valley, where the cold is not greater than in our own climate, throughout the winter. A walk this morning showed us the House-martin, the Crag-martin, and a single individual of the numerous Alpine Swifts, which in the summer haunt the gigantic precipices that frown upon the valley.

We have seen how the Swallow-tribe departs from the Alps, and have also learnt something of the movements and migration of other birds; but I have still to discover in which direction the tenderer birds, the various members of the tribe of warblers, find a way to their southern winter home. I can hardly believe that they can traverse the wild and shelterless mountain passes with their 
short wings and fragile bodies; yet in the long sea voyages which they make they are no less at the mercy of the elements than they would be when in the jaws of the most savage defile of the St. Gotthard.

While I have been fortunate in seeing so much in the course of a very few days, it is obvious that much remains to be discovered, and that future visits to Switzerland, whether in spring or autumn, may not be without their reward; for I have little doubt that there is no European region where the peculiar conditions of temperature, and the extraordinary variety of food, are so likely to produce abnormal effects on the living population-effects which as yet are perhaps comparatively little understood. I feel that my hastily collected information is but a single item in the vast repertory of material which stands ready to the hand of any one whose fortune may send him here at the right time, and with the requisite qualifications. Many Englishmen now pass the Alps in spring by way of the St. Gotthard railway on their return from Italy and the Riviera; if among these there be 
any that are curious about birds, let them halt for a day or two on each side of the pass, and learn what they can of the arrival of migrants from the south. And let me add, that any occupation which brings a foreigner into close contact with the more intelligent Swiss, especially at a time when they are not hard driven by the touring world of all nations, will give new life and interest to even the shortest visit to a country whose history and institutions are as wonderful as its scenery, or as its animal and vegetable life. We are apt to think of the Swiss as a self-seeking people, whose only object is to make capital out of the natural beauties of the extraordinary land they live in. But this is not a happy impeachment in the mouth of Englishmen, who know so well how to make the best of their own resources, and who have contributed not a little to stimulate the ardour of the Swiss for gain and speculation. He who would really know the peasant of the Alps must see him in his natural state, struggling hard against adversity, heavily taxed for education and improvements, loving labour and doing it cheerfully; 
a human being wrestling hard with Nature, who yields her wealth for him with a very sparing hand, while she lavishes upon the birds that live around him untold abundance and endless resource.

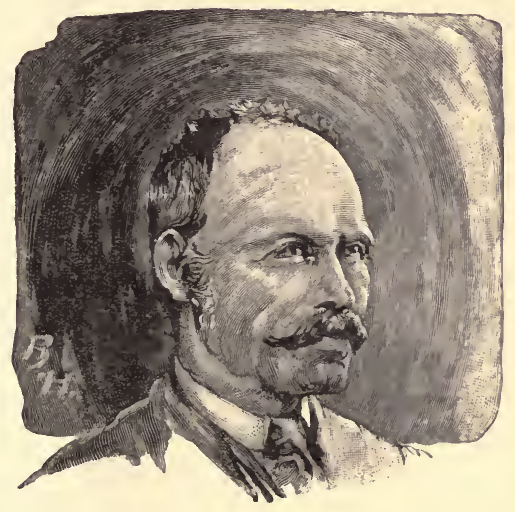

JOHANN ANDEREGG. 


\section{CHAPTER VII.}

THE BIRDS OF VIRGIL.

IT might naturally be supposed, that an Oxford tutor, who finds his vocation in the classics and his amusement in the birds, would be in the way of noticing what ancient authors have to say about their feathered friends and enemies. One Christmas vacation, when there was comparatively little to observe out-of-doors, I made a tour through the poems of Virgil, keeping a sharp look-out for all mention of birds, and compiled a complete collection of his ornithological passages. I chose a Latin poet because in Latin it happens to be easier to identify a genus or species than it is in Greek; and I chose Virgil partly because the ability to read and understand him is to me one of the things which make life most worth living, and partly because I know that there is no 
other Latin poet who felt in the same degree the beauty and the mystery of animals.

I believe there are still people who think of Virgil as a court-poet, writing to order, and drawing conventional ideas of nature from Greek authors of an earlier age. This is, of course, absolutely untrue. Virgil's connection with $\mathrm{Au}$ gustus was accidental, and was probably no more to the poet's taste than any other result of an education and an occasional residence in the huge city of Rome. If we compare what is known of his life with the general character of his poetry, we get a very different result.

The first sixteen years of his life were spent in his native country of Cisalpine Gaul, almost under the shadow of the Alps, three hundred miles away from Rome. His parents were 'rustic,' and he himself was brought up among the woods and rushy meads of. Mantua and Cremona. "Doubtless there is many a reminiscence of his early years in the Georgics, where his love of the woods, in which he must have wandered as a boy, meets us in every page." ${ }^{1}$ In that day it is

1 Ancient Lives of Virgil (Prof. Nettleship), p. 33. 
probable enough that the great plain of the Po was still largely occupied by those dense forests, the destruction of which is said to be the chief cause of the floods to which the river is liable. Much land must also have been still undrained and marshy: and we can still trace in the neighbourhood of Mantua the remains of those ancient lake-dwellings which an ancient people had built there long before the Gauls, from whom our poet was perhaps descended, had taken possession of the plain. These woods and marshes, as well as the land which Roman settlers had tilled for vine or olive, must have been alive with bircis in Virgil's day. There would be all the birds of the woods, the pigeons and their enemies the owls and hawks; there would be cranes and storks in their yearly migrations, and all manner of water-fowl from the two rivers Po and Mincio, and from the Lacus Benacus (Lago di Garda) which is only about twenty miles distant. It would be strange indeed, if, even when following the tracks of a Greek poet, Virgil had not in his mind some of the familiar sights on the banks of Mincius. 
But later in life he was at least as much in Southern as in Northern Italy. That the first three Georgics were written, or at least thought out, on the lovely bay of Naples, is certain from the lines at the end of the fourth Georgic:-

Illo Virgilium me tempore dulcis alebat

Parthenope, studiis florentem ignobilis oti. ${ }^{1}$

Here were all the sea-birds, and the wild-fowl that haunt the sea; here, as we shall see, the summer visitors might land on their way from Africa. Here, from the sea and all its varying life, the poet's mind would enrich itself with sights unknown to him in the flat-lands of the Padus, and grow to understand more fully day by day the impressions-often dull ones-which Nature had made on the poets who had sung before him. Rome he never loved, though he had a house there: perhaps he had seen enough of the huge city during the years given to the dreary rhetorical education of the day, after first leaving his home.

1 I Virgil then, of sweet Parthenope The nursling, woo'd the flowery walks of peace Inglorious, \&c. 
He loved Campania, and he loved Sicily ${ }^{1}$; at Tarentum also he is found, probably visiting the friendly and jovial Horace. The hill-country of the peninsula, and of the island that belongs, to it, became a part of his poetical soul; and as he probably spent much of his time at his own Cisalpine farm, after he was restored to it by his patron's kindly influence, he must have been constantly moving among all the phases of Italian landscape-in the plain, on the hills, by the sea.

Everything, then, in Virgil's history, shows him a genuine poet of the country, and at the same time no one who really knows his poems can deny that they fully bear out the evidence of his life. It is true that he drew very largely on other poets, and could not "disengage himself from the antecedents of his art." From Homer, Hesiod, Aratus, or Theocritus, for example, come nearly all the passages in his works in which birds are mentioned. But though they descend from these poets, and bear the features of their ancestors,

1 " Habuit domum Romae Esquili.s juxta hortos Maecenatianos, quamquam secessu Campaniae Siciliaeque plurimum uteretur." (Life by Suetonius, ch. 13.) 
they are yet a new and living generation, not lifeless copies modelled by a mere imitator; and their beauty and their truth is not that of Greek, but of Italian poetry. Let any one compare the translations of Aratus by other Roman hands, by Cicero, Festus, and Germanicus, with Virgil's first Georgic, and he will not fail to mark the difference between the mere translator and the poet who breathes into the work of his predecessors a new life and an immortal one. There is hardly to be found, in the whole of Virgil's poens, a single allusion to the habits of birds or any other animals which is untrue to fact as we know it from Italian naturalists. Here and there, of course, there are delusions which were the common property of the age. If, for example, he tells us in the fourth Georgic that bees

oft weigh up tiny stones

As light craft ballast in the tossing tide,

Wherewith they poise them through the cloudy vast :

let us remember that the true history of bees has been matter of quite recent discovery. And we may note at the same time that Pliny, a professed naturalist, living at least a generation after Virgil, 
has actually asserted that cranes, when flying against the wind, will take up stones with their feet, and stuff their long throats full of gravel, which they discharge when they alight safely on the ground ! ${ }^{1}$

Virgil mentions about twenty kinds of birds, most of them several times. These twenty kinds do not correspond so much to our species as to our genera; for the Greeks and Romans, I need hardly say, had only very rough-and-ready methods of classification, just as is the case with uneducated people at the present day. When they found birds tolerably like each other, they readily put them down as of the same kind, rarely marking minor differences. Thus corvus appears to stand for both crow and rook; picus stands for all the woodpeckers inhabiting Italy; by accipiter may be understood any kind of hawk. But in spite of this difficulty, it is sometimes possible to make out the particular species which is alluded to, partly by getting information as to those which

${ }^{1}$ Plin., $N . H$. x. 6o. Aristotle refutes the fable, which is alluded to by Aristophanes in the Birds ( $\mathrm{rr}_{37}$ ). See Arist., H. $N$. viii. I 4.5 . 
are found in Italy at the present day, partly by comparing Virgil with Pliny and other Roman writers, and where Virgil is using a Greek original, by trying to discover, chiefly through Aristotle's admirable book on natural history, what bird is indicated by the Greek word translated, and whether that bird is an Italian bird as well as Greek, and therefore likely to be known to Virgil at first hand.

I am not going to trouble my readers with much of the uninteresting detail of an inquiry like this (in which indeed the game might seem to be hardly worth the candle), but merely to give them some idea of the bird-knowledge on which this greatest of Roman poets drew, whether at first or second-hand, for description or illustration ; and in so doing to make clear to them, so far as I can, the particular kinds of birds which he had in his mind. I shall quote him in the original, but shall add translations in footnotes : in the Georgics, his poem of husbandry, I take advantage of a poet's translation, that of my friend Mr. James Rhoades, which cannot easily be outdone either in exactness of scholarship or in beauty of diction; 
and in the Aeneid I make use of Mr. Mackail's prose translation, which I prefer on the whole to any poetical version I know. One passage from the Eclogues I have translated myself.

The first birds we find mentioned in the poems are the Pigeons, and we may as well begin with them as with any other. Meliboeus tells Tityrus that the farm to which he is returned after a long exile-the same farm which the poet himself lost and found again-shall yield him much true comfort and delight, even though he find it overgrown with reeds, and spoilt with the stones and mud of overflowing Mincius :-

Nec tamen interea raucae, tua cura, palumbes, Nec gemere aeria cessabit turtur ab ulmo. ${ }^{1}$

Here two distinct species are clearly meant by the words palumbes and turtur. About the latter of these there is no difficulty; from all that is told us of it we gather that it is the same bird which the French still call tourterelle and the Italians tortorella, and which we know as the Turtle-

1 And all the while, with hollow voice, thine own Loved wood-pigeon shall soothe thee, nor alone, For from the lofty elm the dove shall ever moan. 
dove; it is still found in small numbers passing the summer and breeding in Italy, and is most frequent in the sub-alpine region of which Virgil is here writing. But what bird is here meant by palumbes? Both this word and its near relative columba must be translated by pigeon, but can we distinguish them as different species? Here the commentaries and dictionaries give us no substantial help, and I may be pardoned for pausing a moment to consider a question of some interest to historical ornithologists.

There are at the present day three kinds of pigeons beside the turtle-dove just mentioned, which are found in Italy; they are the same three which we know in England as the Wood-pigeon or Ring-dove, the Stock-dove, and the Rock-dove or Blue-rock. Of these the last, which with us is the rarest, only found on certain parts of our coast, is by far the most abundant in Italy, and is the only one which habitually breeds there. The other two species pass over Italy in spring and autumn regularly, but seldom or never stay there; they go northwards in the spring from Africa and the East, and return again in the autumn after 
breeding in cooler climes. But it is fairly certain that in ancient times two species of pigeons bred in Italy: (I) the bird meant by palumbes, of which Virgil makes the shepherd Damoetas say in the third Eclogue that he has "marked the place where they have gathered materials for nesting," 1 and of which Pliny tells his readers that when they see this bird upon her nest they may know that midsummer is past (Pliny, Nat. Hist. xviii. 267); (2) the bird named columba, which word, though etymologically the same as palumbes, is used by Pliny, and also by the Roman agricultural writers, to represent a bird which is certainly to be distinguished from palumbes. ${ }^{2}$ The columba was in fact the tame pigeon of the Romans: it was also their carrier-pigeon; for in the siege of Mutina, в.c. 43, the besieged general communicated with the relieving force by means of columbae, to the feet of which letters were attached (Plin. $x$. I IO). The words may here and there be used loosely, and it is possible that attempts may have been made to domesticate the palumbes as well as

1 Eclogue iii. 68.

2 Columella viii. 8. Cato de Re Rustica, 9o. 
the columba; but in the vast majority of passages the columba is certainly either the domestic bird or a wild bird of the same species, while palumbes is some other kind of pigeon.

Even in Virgil the distinction is maintained; for while palumbes breeds in the elm in the first Eclogue, already quoted (which poem, it should be noted, is genuinely north-Italian, and independent of a Greek original), columba on the other hand has her nest in a rock, as the following well-known and beautiful passage will plainly show-

Qualis spelunca subito commota columba,

Cui domus et dulces latebroso in pumice nidi,

Fertur in arva volans, plausumque exterrita pennis

Dat tecto ingentem, mox aere lapsa quieto

Radit iter liquidum, celeres neque commovet alas.

And in the same fifth Aeneid, the bird which served as a target in the archery contest-a domestic bird, we may suppose-was a columba, not a palumbes.

Now it is a fact almost universally recognized by modern ornithologists that our domestic pigeon is in all its varieties descended from the wild Rock-dove; and thus when we find that the 
Romans used columba to denote their domestic bird, and also a wild bird which made its nest in rocks, the conclusion is almost certain that by that word we are to understand our Blue-rock pigeon (Columba livia); and if this is so, by palumbes must be meant one of the other two Italian pigeons, the Wood-pigeon (Columba palumbus, Linn.) or the Stock-dove (Columba aenas, Linn.). Both species, as I have said, are now birds of passage in Italy, while the Blue-rock is resident ; and Pliny tells us of the palumbes that it arrived every year in great numbers from the sea-he does not say at what season. Perhaps the Stockdove ${ }^{1}$ is the more likely of the two to have been the bird generally meant by palumbes; but it is quite possible that, like the unskilled of the present day, the Romans confounded the two species, and wrote of them as one.

But there is still a difficulty. The palumbes in the time of Virgil and Pliny seems to have bred in Italy; Pliny knew all about their breeding ( $x$. 147 and 153), and Virgil makes Damoetas mark

1 Philemon Holland so translates palumbes in his version of Pliny. 


\section{Passion of Italians for Birds.}

the place where their nesting is going on. But it is now very rarely, if we may trust Italian naturalists, that either Ring-dove or Stock-dove passes a summer in Italy. Birds seek a cool climate for their breeding-places; probably because in very hot countries the food suitable to their nestlings will not be found in the breedingseason. Has the climate of Italy become hotter in the last two thousand years, discouraging these birds from lingering south of the Alps?

This is an old question which has been well thrashed out by the learned, and the general conclusion seems to be in the affirmative. The last eminent writer on the subject takes this view, ${ }^{1}$ and his argument would receive a decided clinch if it could be proved that certain kinds of birds, which formerly bred in the country, do so no longer, and that this is not due to other causes, such as the well-known passion of the Italians for killing and eating all the birds on which they can lay their hands.

If we now turn to the first Georgic, in which, following the Greek poet Aratus with freedom

${ }^{1}$ Nissen, Italische Landeskunde, p. 374. 
and discretion, Virgil has told us more of animal life than in all the rest of his poems, we find frequent mention of the long-legged and longbilled birds with which he must have been very familiar in his boyhood at Mantua. The first of these we meet with is the Crane (Latin grus). About the meaning of the word grus there can be no doubt; it would seem that the Crane was a bird accurately distinguished by the forefathers of our modern Aryan peoples even before they separated from each other. The Greek word $\gamma^{\prime}$ śpavos, the Latin grus, the German Kranich, and the IVelsh garan are all identical, and point to a period when the bird was known by the same name to the whole race. Probably it was much more abundant both in Europe and Asia, at a time when the face of the country was covered by vast tracts of swamp and forest. Even now, at the period of migration, they swarm in the East ; "the whooping and trumpeting of the crane," says a great authority (Canon Tristram), "rings through the night air in spring, and the vast flocks we noticed passing north near Beersheba were a wonderful sight." 
Virgil mentions the Crane in two passages as doing damage to the crops: and this is fully borne out by modern accounts from Asia Minor and Scinde, quoted by Mr. Dresser in his Birds of Europe. The poet says of them (Georgic i. is 8)-

Nec tamen haec cum sint hominumque boumque labores

Versando terram experti, nihil improbus anser

Strymoniaeque grues et amaris intuba fibris

Officiunt aut umbra nocet. ${ }^{1}$

And in line 307 of the same book he tells the husbandman that the winter is the time to catch them :

Tum gruibus pedicas, et retia ponere cervis

Auritosque sequi lepores ; ${ }^{2}$

a passage from which it might appear as if the Crane were snared as an article of food, not only as an enemy to the agriculturist. And indeed in Pliny's time the epicure's taste was all in favour

1 But no whit the more

For all expedients tried and travail borne

By man and least in turning oft the soil, Do greedy goose and Strymon-haunting cranes And succory's bitter fibres not molest Or shade not injure-

2 Time it is to set

Snares for the crane, and meshes for the stag, And hunt the long-eared hares. 
of cranes against storks; but when Virgil wrote, the reverse was the case. This little fact, so characteristic of the sway of fashion over the gourmand of that luxurious age, was recorded by Cornelius Nepos, and is quoted from him by Pliny (Nat. Hist. x. 6o).

The Crane is now a bird of passage in Italy, and the Stork also; they appear in spring on their way to northern breeding-places, and in autumn reappear with their numbers reinforced by the young broods of the year. These habits seem to have been the same in Virgil's day. In the passage just quoted (Georgic i. I 20) it is evidently in the spring that the bird was hurtful to the crops, as the seed was to be sown in the spring (line 43 , etc.).

On the other hand, in line 307 , the Crane is to be snared in the winter; yet I can hardly believe that any number could have stayed in I taly during winter, if the climate was then colder than it is now. Moreover, Pliny speaks of the Crane as 'aestatis advena,' that is, a summer visitor, as opposed to the Stork, who was a winter visitor. But these Latin words 'aestas' and 'hiems' are 
to be understood loosely for the whole warm season, and the whole cold or stormy season ; and if cranes came on their passage northwards, when warm weather began, they must also have appeared, on their return journey, when cold weather was beginning; so that both crane and stork might equally be styled 'aestatis advena,' or 'hiemis advena.' Pliny was surely making one of his many blunders when he distinguished the two birds by these two expressions.

The migration of such great birds as these, unlike those of our tiny visitors to England, could hardly escape the notice even of men who knew nothing of scientific observation. Virgil has given us a momentary glimpse of the Crane's migration in spring; he is following in the tracks of Homer, but as a Mantuan he must have seen the phenomenon himself also.

Clamorem ad sidera tollunt

Dardanidae e muris ; spes addita suscitat iras ;

Tela manu jaciunt; quales sub nubibus atris

Strymoniae dant signa grues, atque aethera tranant

Cum sonitu, fugiuntque Notos clamore secundo. ${ }^{1}$

1 The Dardanians on the walls raise a shout to the sky. Hope comes to kindle wrath ; they hurl their missiles strongly; 
Here, as they fly before a southern wind, they are on their way to the north in the spring. But in another passage he seems rather to be thinking of autumn; it is where he is telling the husbandman how to presage an approaching storm, such a storm as descends in autumn from the Alps upon the plains of Lombardy :-

\section{Nunquam imprudentibus imber}

Obfuit ; aut illum surgentem vallibus imis

Aeriae fugere grues, aut bucula coelum

Suspiciens patulis captavit naribus auras,

Aut arguta lacus circumvolitavit hirundo. ${ }^{1}$

The general tenor of the whole passage of which these lines are a fragment, as well as their original in the Diosemeia of Aratus, points to the approach of 'hiems,' the stormy season, as the event indicated; the falling leaves dance in air, the feathers

even as under black clouds cranes from the Strymon utter their signal notes and sail clamouring. across the sky, and noisily stream down the gale.-Aen. x. 262 foll.

1 Never at unawares did showers annoy : Or, as it rises, the high-soaring cranes Flee to the hills before it, or, with face Upturned to heaven, the heifer snuffs the gale Through gaping nostrils, or about the meres Shrill-twittering flits the swallow.-Georgic i. 373. 
of the moulting birds float on the water, but the swallow is not yet gone. The deep Alpine valleys seethe with swirling mist, which rises into gathering cloud, and soon becomes stormy rain beating upon the plains, as we may see it in any 'Loamshire' of our own, that lies below the stony hills of a wilder and wetter country-side. In this striking and truthful passage, Virgil has not followed his model too closely, but was evidently thinking of what he must often have witnessed himself.

The Stork is only mentioned by Virgil in a single passage-

\section{Cum vere rubenti}

Candida venit avis longis invisa colubris. ${ }^{1}$

Doubtless the bird arrived in great numbers in spring on the Mantuan marshes, and found abundance of food there in the way of frogs and snakes. Its snake-eating propensity was considered so valuable in Thessaly, that the bird was preserved there by law, says Aristotle. ${ }^{2}$ But did it remain to breed in Italy? It is remarkable

\section{In blushing spring}

Comes the white bird long-bodied snakes abhor.-Georg. ii. 320 .

2 Mirabilia 23. 
that both Aristotle and Pliny have very little to say of its habits, and hardly anything as to its breeding; and if the Stork had been a bird familiar to them, they could hardly have failed to give it a prominent place in their books. At the present time it scems to pass over Italy and Greece on its passage northwards, never staying to breed in the former country and rarely in the latter; yet this can hardly be owing to temperature, as it breeds freely in the parallel latitudes of Spain and Asia Minor.

As regards ancient Italy, however, the question seems to be set at rest by a very curious passage from the Satyricon of Petronius, which has been kindly pointed out to me by Mr. Robinson Ellis. It is remarkable not only for its Latin, but for its concise and admirable description of the characteristic ways of the Stork :

Ciconia etiam grata, peregrina, hospita, Pietaticultrix, gracilipes, crotalistria, Avis exsul hiemis, titulus tepidi temporis, Nequitiae nidum in cacabo fecit meo. ${ }^{1}$

${ }^{1}$ See Petronius, Satyr. 55. Cp. also Juv. Sat. I, line I 1 6, and Mayor's note. In the London Zoolngical Gardens, in March 
"A Stork too, that welcome guest from foreign lands, that devotee of filial duty, with its long thin legs and rattling bill, the bird that is banished by the winter and announces the coming of the warm season, has made his accursed nest in my boiler." I am reminded also of a story, which has the authority both of Jornandes and Procopius, that at the siege of Aquileia in A.D. 452, Attila was encouraged to persist by the sight of a Stork and her young leaving the beleaguered city. "Such a domestic bird would never have abandoned her ancient seats unless those towers had been devoted to impending ruin and solitude." ${ }^{1}$ Here then we seem to have another cxample of a bird abandoning its ancient practice of breeding, occasionally at least, in Italy. If this is due to persecution, the persecutors have made a great mistake. The Stork does no harm to man, but rather rids his fields of vermin; the Crane, which belongs to a different order of birds, may do serious damage, as we have seen, to

ı 889, a pair of Storks were illustrating Petronius' lines admirably-except in that they were captives.

${ }^{1}$ Gibbon, vol. iv. p. 240, ed. Milman, 
cultivated land, like the 'improbus anser,' and other birds which Virgil in the first Georgic instructs the husbandman to catch with lime or net, or to frighten away from the fields. ${ }^{1}$

Let us now turn to the big black birds of the race of the Crows, which are always so difficult to distinguish from one another: for the Roman savant not less difficult than for our own unlearned. There are to be found in Italy at the present day the Raven, the Crow, the Rook, the Jackdaw, the Chough, and the Alpine Chough; all of these seem to be fairly common and resident in one or other part of the country, except our familiar friends the Crow and the Rook, the former of which is very rare, and the latter hardly more than a bird of passage. We cannot of course expect to find these accurately distinguished by the ancient Italians; and there is in fact still some uncertainty as to the identification of certain birds of this kind mentioned by Virgil.

The two commonest of these are the corvus and the comix-words which undoubtedly represent two different species. The Roman augurs, who 
were always busily engaged in observing birds (and it were to be wished that they had observed them to some better purpose), clearly distinguished corous and cornix. ${ }^{1}$ So also did Pliny, ${ }^{2}$ in the following curious passage: "The corvus lays its eggs before midsummer, and is then in bad condition for sixty days, up to the ripening of the figs in autumn: but the cornix begins to be disordered after that time." Virgil also uses the words for two distinct species; his comix is solitary-

Tum cornix plena pluviam vocat improba voce Et sola in sicca secum spatiatur arena $;^{3}$

while corvus is gregarious, as is shown in the following memorable description of Nature and of the birds taking heart after the storm has passed :

Tum liquidas corvi presso ter gutture voces Aut quater ingeminant, et saepe cubilibus altis, Nescio qua praeter solitum dulcedine laeti,

${ }^{1}$ Cic. de Div. i. 29.

$$
{ }^{2} \text { N. HI. x. } 3^{2 .}
$$

3 Then the crow

With full voice, good-for-nought, inviting rain, Stalks on the dry sand mateless and alone,-Georg. i. 388. 
Inter se in foliis strepitant; juvat imbribus actis, Progeniem parvam dulcesque revisere natos. ${ }^{1}$

That in these last beautiful lines corvus means a Rook, no Englishman is likely to deny ; yet there are two difficulties to be put aside before we can make the assertion with entire confidence. The first is, that Virgil, here following Aratus, translated by corvus the Greek word xóp $\boldsymbol{\xi}$, which is not generally accepted as meaning a Rook. This is the word which the Greek historian Polybius uses for those naval machines invented by the Romans, in the first war with Carthage, for grappling with a hooked projecting beak the galleys of the enemy; and the rook's bill is hardly so well suited to give a name to such an engine as that of the crow or raven, ${ }^{2}$ which has the tip of the upper mandible sharply bent down-

1 Soft then the voice of rooks from indrawn throat Thrice, four times, o'er repeated, and full oft On their high cradles, by some hidden joy Gladdened beyond their wont, in bustling throngs Among the leaves they riot; so sweet it is When showers are spent, their own loved nests again And tender brood to visit.-Georg. i. 4 ro.

${ }^{2}$ Sundevall (Thierarten des Aristoteles, p. I 23 ) pronounces rópa $\xi$ to have been our Raven. 
wards, like that of most flesh-eating birds. Still I must hold it probable that Aratus here used the word for the rook, as he makes it gregarious, and so, I think, did the Alexandrian scholar Theon, who wrote a commentary on his poem. The only other possibility is that he was thinking of the Alpine Chough, a bird which he might possibly have known, and one of thoroughly social habits. But that Virgil, though he too probably knew this bird, was not thinking of it when he wrote the lines just quoted, I feel tolerably sure; he would most likely have used the word graculus rather than corvus, which would seem never to have been applied, like monedula and graculus, to the smaller bircls of the group, such as the Alpine Chough and the Jackdaw.

The second difficulty lies in the fact that the Rook is now only a bird of passage in Italy, never stopping to breed in the southern part of the peninsula, and very rarely in the northern; while Virgil speaks of the corvi in the last-quoted passage as loving to revisit their nests. But this difficulty has been overcome by the delightful discovery that the Rooks still stay and breed in 
the sub-alpine neighbourhood where Virgil passed his early life. ${ }^{1}$ As I have remarked about the pigeons and the stork, the climate may have been such as would induce some birds to stop south of the great Alpine barrier, which now find there no climate cool enough for breeding; and the Rook was perhaps a more regular resident and breeder then than he is now.

We may conclude then that Virgil's corvus is our old friend the Rook, even if some Latin authors use the word equally for Rook, Crow, and Raven. Pliny for example tells us $(N . H$. x. I 24) that the corrus can be taught to speak (fancy a bird talking Latin, that stiff and solemn speech!), that he eats flesh for the most part, and that he sometimes makes his nest in elevated buildings; feats which we are not used to associate with Rooks. In fact it is plain that Pliny, who was more of a learned book-reader than a careful observer of the minutia of nature, was not quite clear in his notions about the big black birds. But if we can be pretty sure about corvus, what is Virgil's cornix, stalking on the shore in solitary

I See Newton's Yarrell, ii. 290. 
state, and uttering admonitory croaks from the hollow holm-oak? If we consult dictionaries we shall learn that cornix is the Crow or Rook, "a smaller bird than corvus." Where did the dictionaries get this authority for making confusion worse confounded? If Virgil distinguished corvus and comix, and if corvus is the rook, then cornix must be the crow or the raven, and in fact the word probably stands for both. I should incline on the whole to the raven, seeing that at the present day it is much the commoner bird of the two in Italy. Alpine choughs and jackdaws are not wont to stalk about alone; and though the larger chough (our Cornish chough) might do so, and is to be found in the mountain districts of Italy, he cannot well be the bird generally understood by comix. Could a chough learn to talk with his long thin red bill? But Pliny knew of a talking cornix; "while I was engaged upon this book," he says, "there was in Rome a cornix from the south-west of Spain, belonging to a Roman knight, which was of an amazingly pure black. and could say certain strings of words, to which it frequently added new ones." 
Swans are frequently mentioned by Virgil, as by other Latin and Greek poets. This splendid bird must have been much commoner then throughout Europe than it is now, and accordingly attracted much attention. It doubtless abounded in the swampy localities of the north of Italy, and at the mouths of the great rivers of Thrace and Asia Minor, as well as in the north of Europe, where it came to be woven into many a Teutonic fable. Homer has frequent and beautiful allusions to it; and the town of Clazomenae, at the mouth of the river Hermus, has a swan stamped upon its coins.

This Swan of the old poets is without any doubt the whooper (Cycmus musicus), whose voice and presence are still well known in Italy and Greece. Virgil had seen it at Mantua, on the watery plain of the Mincius:

Pascentem niveos herboso flumine cycnos. ${ }^{1}$

And in an admirable simile in the eleventh book of the Aeneid, he likens the stir and dissension in

1 Whose weedy water feeds the snow-white swan. 
the camp of Turnus, when the news suddenly arrives that Aeneas is marching upon them, to the loud calls of this bird:

\section{Hic undique clamor}

Dissensu vario magnus se tollit ad auras :

Haud secus atque alto in luco cum forte catervae

Consedere avium, piscosove amne Padusae

Dant sonitum rauci per stagna loquacia cycni. ${ }^{1}$

We now come to two birds mentioned in the same line of the third Georgic. The poet is telling the farmer to water his flocks in the cool evening of a hot day:

Cum frigidus aera vesper

Temperat, et saltus reficit jam roscida luna,

Litoraque alcyonen resonant, acalanthida dumi. ${ }^{2}$

The first of these birds is also mentioned in a line of the first Georgic, which is mainly taken from Aratus; but it is significant that Aratus does not mention the 'alcyon' either here or anywhere else.

1 With that a great noise rises aloft in diverse contention, even as when flocks of birds haply settle on a lofty grove, and swans utter their hoarse cry among the vocal pools in the fishfilled river of Padusa.-Aen. xi. 456 ; cp. vii. 700.

\section{When cool eve}

Allays the air, and dewy moonbeams slake The forest glades, with halcyon's voice the shore And every thicket with the goldfinch rings.-Geory. iii. 338 . 
Non tepidum ad solem pennas in littore pandunt

Dilectae Thetidi alcyones. ${ }^{1}$

That the 'alcyon' of these two passages is to be identified with our Kingfisher, which is still an Italian bird, and the only one of its kind, I can have no reasonable doubt; for Pliny's description of the bird is too exact to be mistaken. "It is," he says, " a little larger than a sparrow, of a bluegreen colour (colore cyaneo), red in the under parts, having some white feathers close to its neck, and a long thin bill." This description, it is true, is copied almost word for word from Aristotle, the only exception being the allusion to the white feathers on the side of the neck, which are a well-known feature in the Kingfisher. ${ }^{2}$ Whether both were thinking of the same bird it is impossible to decide; but that Pliny was describing

${ }^{1}$ Not to the Sun's warmth there upon the shore

Do halcyons dear to Thetis ope their wings.-Georg. i. 398 .

2 This exception is singular, as Pliny seems to depend on Aristotle for everything else which he tells about the bird. I am inclined to think that in this case Pliny must have supplemented his master's account from his own observation. He had a villa on the bay of Naples, which bay was probably the 'littus' referred to by Virgil; and both may here have seen the bird on the shore. 
our Kingfisher, and believed Aristotle to have done so in the passage he copied, it is almost unreasonable to doubt.

It is, however, an open question whether the bird ordinarily known to the Greeks as $\dot{\alpha} \lambda x u(i \nu$ is to be identified with the Kingfisher. The greatest living authority on the birds of the Levant, Canon Tristram of Durham, tells me that he has convinced himself that it is not the Kingfisher, but the Tern or Sea-swallow: a rare coin of Eretria led him to this conclusion, on which a Tern is figured, sitting on the back of a cow. ${ }^{1}$ And it must be allowed that the Greeks seem to have thought of their $\dot{\alpha} \lambda x \boldsymbol{\omega} \dot{\nu}$ as a sea bird no less than as a river bird. Aristotle remarks that it goes up rivers, but he seems to have thought of it mainly as a sea bird, and a well-known passage in the seventh Idyll of Theocritus appears to bear him out. But I am not here specially concerned with Greek ornithology, and what Virgil says of

1 I have seen a photograph of this coin, and satisficd myself that the bird was meant for a Tern. But I have so far been unable to discover any connection between Eretria and the adrvis. Sundevall is confident that Aristotle's bird is the Kingfisher. 
the alcyon piping and pluming himself on the shore is perfectly consistent with the habits of the bird. I have myself seen it on the coast of Dorset, "pennas in littore pandens," and taking flight over a bay full half a mile in width. A greater difficulty lies in the alleged vocal powers of the bird; they sing, Pliny tells us, in the reeds, and Virgil's alcyon makes the shore echo with his voice. The Kingfisher, so far as I know, is a silent bird except when disturbed; he will then utter a shrill pipe as he flies away. But I am quite at a loss to explain his singing; except by supposing that this was one of several curious delusions that had gathered round a curious bird. ${ }^{1}$

The other bird mentioned in the lines last quoted is, and perhaps will remain, a puzzle. Mr. Rhoades makes it the Goldfinch, following the commentators, who themselves follow an old tradition which will not bear criticism, and in favour of which I can find nothing more con-

${ }^{1}$ E. g. Aristotle gives, and Pliny copies from him, an extraordinary account of the nest and eggs. $N . H$. ix. I4. See Note $\mathrm{C}$, at end of volume. 
vincing than the argument that acanth ${ }^{1}$ means in Greek a thorny or prickly tree, while the Goldfinch's favourite food is the seed of the thistle. Let us notice, however, first, that it is not the way of the Goldfinch to sit in a thicket and sing, as Virgil describes the Acalanthis; it is a restless, lively, aërial bird, fond of singing on the wing, and by no means disposed to lurk under cover; and secondly, that the word $\alpha^{\prime} x \alpha \nu f \alpha$ does not necessarily mean a thistle, but is equally applied to all kinds of thorny trees and shrubs, ${ }^{2}$ such as the dumi in which Virgil makes the voice of the bird resound.

Where did Virgil get this Greck word acanthis ${ }^{3}$ or acalanthis, which he thus appropriated to express some bird familiar to himself? Probably from a very beautiful passage in 'Theocritus' seventh Idyll, where, lying on the vinc-leaves,

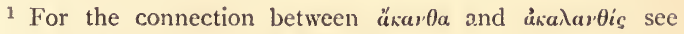
Conington's note on Georg. iii. 338 .

2 Theophrastus, for example, applies it to the Egyptian mimosa, the thorns of which lately proved so damaging to our troops in the Soudan. (Len7, Botanik der Griechen, p. 735.)

3 There is another reading, 'et acanthida.' 
Damoetas and Daphnis hear the birds singing, and the murmur of the bees :-

\section{"A}

"the larks and the acantlides were singing, and the turtle-dove was moaning." But what kind of bird was Theocritus himself thinking of ? Here we must have recourse to Aristotle, who in his book on birds describes the bird known to the Greeks as acanthis as being "of poor colouring and habits, but having a clear shrill voice."1 This cannot possibly be the Goldfinch, the happiest and most brightly coloured of our smaller English birds; one too whose song would hardly be picked out to be described as $\lambda$ ı $y$ upá, which word denotes a sustained high and shrill sound, and would not well express a twitter or a quiet warble. Sundevall, the Swedish scholar-naturalist, has pronounced this acanthis of Aristotle to be the linnet; a conclusion with which no one would be likely to agree who is fresh from a sight of that lively bird in its splendid summer plumage, or who knows its gentle twittering song. Let us remember that

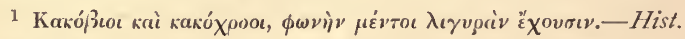
Anim. ix. I 7 . 
Aristotle is of all naturalists, down to the time of Willoughby and Ray, the most exact and trustworthy, and that when he uses an adjective to describe a bird or its voice, he means something exact and definite, and is not talking loosely.

Before we try to come to a conclusion about the $\dot{\alpha} x_{\alpha} v$ is $_{\text {, }}$, let us note that Aristotle mentions another small bird, the $\dot{\alpha} x \alpha \nu \theta v \lambda \lambda$ is, which, from the name, we may guess to have been one of the same kind as the acanthis. This bird builds a nest which is round and made of flax, and has a small hole by way of entrance. Now let us observe that Italy and Greece are swarming for the greater part of the year with a variety of those small brown or dusky-coloured birds which naturalists roughly call 'warblers' - birds for the most part apt to creep and lurk about in thickets or small trees, and having voices more or less shrill, which may very well indeed be called $\lambda$ srupai. In England we have some species of this order which are abundant in the summer; c. $g$. in Oxford, the chiffchaff, willow-wren, sedgewarbler, and reed-warbler - the two former of which build spherical nests on the ground with 
a small entrance-hole. These birds correspond with both of Aristotle's birds in being xaxíßrol-i.e. leading a poor lurking life; xaxóxpoor, as being all very sober-coloured and difficult to distinguish from one another, even by a modern expert; in having a clear, sustained, or sibilant song, ${ }^{1}$ and lastly in building-some of them, that is-round nests with small holes for ingress and egress.

Now in Italy and Greece the number of species of these little birds is much larger than in England, and it is hardly possible that they could have escaped the notice of either poet or naturalist. It is with these that I think we are to identify the acanthis and acanthyllis of Aristotle, the acanthis of Theocritus, and the acalanthis of Virgil, with which we started this too lengthy discussion. Towards the evening of a hot summer day, when the flocks have to be watered, as he enjoins the shepherd, these little warblers would begin their song afresh, and sing, as does our own Sedge-

1 A sibilant trill is probably what is meant in a passage of

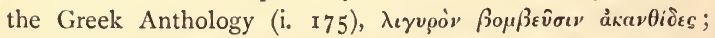
suggesting the Grasshopper Warbler (see p. 154), or the Sedgewarbler. 
warbler, far on into the night. Neither Goldfinch nor Linnet would be likely to sing at that time in a thicket of thorn-bushes: those fairy creatures would be playing in the cool air, or seeking the water for a refreshing bath or draught.

There are several other passages in Virgil which invite both translation and discussion; but I must be content with giving one or two, and must dispense with lengthy remarks on them. Every Latin scholar knows the description, in the first Georgic, of the birds flying shorewards before the storm:-

Continuo, ventis surgentibus, aut freta ponti Incipiunt agitata tumescere et aridus altis Montibus audiri fragor, aut resonantia longe Litora misceri et nemorum increbrescere murmur. Jam sibi tum curvis male temperat unda carinis, Cum medio celeres revolant ex aequore mergi Clamoremque ferunt ad litora, cumque marinae In sicco ludunt fulicae, notasque paludes

Deserit atque altam supra volat ardea nubem. ${ }^{1}$

${ }^{1}$ Georg. i. 356 foll. I quote this time Mr. R. D. Blackmore's admirable rhyming version.

Ere yet the lowering storm breaks o'er the land A sullen groundswell heaves along the strand, On mountain heights dry snapping sounds are heard, The booming shores bedrizzled are and blurred, And soughs of wind sigh through the forest stirred. 
The words mergi and fulicae in these lines have been the subject of much discussion among commentators. That Virgil meant by mergus some particular bird known to himself, there can be little doubt; for he has transferred to the mergus what Aratus (here his original) says of the Heron (śpwòrós). And rightly so; for the Heron never goes out to sea to fish, as it needs standing ground and is no swimmer. This mergus stands probably for the Gull in a generic sense ; Virgil had doubtless seen them flying to the Campanian coast before a coming storm, and altered Aratus accordingly. The fulica marina is translated by Mr. Blackmore 'sea-coot,' which is correct but meaningless, and by Mr. Rhoades ${ }^{1}$ 'cormorant'; but in this case we have no means of determining the species of which the poet was thinking. He used

'The wave already scarce foregoes the hull

When homeward from the offing flies the gull,

With screams borne inland by the blast; and when

Sea-coots play round the margin of the fen;

The heron quits the marsh where she was bred

And soars upon a cloud far overhead.

${ }^{1}$ Following Keightley's Commentary, which is the best we possess on Georg. i. $35^{1-423}$. 


\section{Simile of the Swallow.}

the word fulica, a coot, to help him out in naming a bird which was something like a coot, but a bird of the sea, and one for which he had no word ready, or none that would suit his metre.

Another beautiful passage is to be found in the twelfth book of the Aeneid; it is one in which our poet is evidently describing an everyday sight of an Italian spring and summer, and writing independently of an original :

Nigra velut magnas domini cum divitis aedes

Pervolat et pennis alta atria lustrat hirundo,

Pabula parva legens, nidisque loquacibus escas;

Et nunc porticibus vacuis, nunc humida circum

Stagna sonat : similis medios Juturna per hostes

Fertur equis, rapidoque volans obit omnia curru. ${ }^{1}$

Though it seems odd to compare to a swallow the fierce female warrior careering in her chariot, it should be noted that Juturna's object is not to fight, but by constant rapidity of movement to keep Turnus and Aeneas from meeting each other. This simile is, I think, the most perfect

${ }^{1}$ Aen. xii. 473. Mr. Mackail translates: "As when a black swallow flits through some rich lord's spacious house, and circles in flight in the lofty halls, gathering her tiny food for sustenance to her twittering nestlings, and now swoops down the spacious colonnades, now round the wet ponds," \&c. 
passage about the Swallow that I have ever met with in poetry.

The hirundo of the Romans had of course a generic sense, and included all the different species of Martin and Swallow. When Virgil writes (Georg. iv. IO 7) of the chattering himundo which hangs its nest from the beams, he clearly means the House-martin; for the Swallow places his upon the rafters, while the Martin does exactly what Virgil describes. Both Aristotle and Pliny distinguish three or more species of these birds, the Swallow, Sand-martin, Swift, and possibly the Crag-martin; and their habits seem to have been the same as at the present day.

I shall not trouble my readers with any of Virgil's passages ${ }^{1}$ about the Hawks and Eagles, in all of which he follows Homer more or less closely. Nor need we pause to dwell on the single passage in which he has mentioned the Nightingale; for, beautiful as it is, it is not only based on Homer, but is inferior in truth to Homer's lines. The older poet sings truthfully of the Nightingale "sitting in the thick foliage 1 Aen. ix. $564 ;$ xi. 721,751 ; xii. 247 . 


\section{The Nightingale in Virgil.}

of the trees," and "pouring a many-toned music with many a varied turn ;" but Virgil has neither of these touches. Still his lines have a beauty of their own :

Qualis populea moerens philomela sub umbra Amissos queritur foetus, quos durus arator Observans nido implumes detraxit ; at illa Flet noctem, ramoque sedens miserabile carmen Integrat, et moestis late loca questibus implet.?

I will finish this chapter by quoting one more passage; in which I think we may see Virgil's own observation of the habits of birds. It is a famous passage in the sixth Aeneid, where Aeneas has embarked with Charon to cross the Styx, and the ghosts collect upon the bank to beg for passage to the other side; they gather in numbers,

Quam multa in silvis autumni frigore primo Lapsa cadunt folia, aut ad terram gurgite ab alto

${ }^{1}$ As in the poplar-shade a nightingale Mourns her lost young, which some relentless swain, Spying, from the nest has torn unfledged, but she Wails the long night, and perched upon a spray With sad insistence pipes her dolorous strain, Till all the region with her wrongs o'erflows. 
Quam multae glomerantur aves, ubi frigidus annus, Trans pontum fugat, et terris immittit apricis. ${ }^{1}$

This passage is a very embarrassing one, and is not sufficiently cleared up by the commentators. The well-known lines which they quote from Homer (Iliad, iii. 3 foll.), though they may have suggested, are very far from explaining it. The ghosts are praying piteously for passage, and hold out their hands in entreaty, "with strong desire for the further shore: " and they are compared to birds driven on by cold weather, and seeking entrance to warmer lands. Ghosts and birds are alike uneasy; they long for relief in a home that is now their natural one. So far so good. But the birds are arriving from the sea (gurgite $a b$ alto) in the autumn, and this must be a northern sea, and the coast on which they collect must be the threshold of a more genial climate. Where could Virgil have seen birds collecting on the shore from the North, on their way to the South?

1 Aen. vi. 309. "Multitudinous as leaves fall dropping in the forests at autumn's earliest frost, or birds swarm landward from the deep gulf, when the chill of the year routs them over seas and drives them to sunny lands." 


\section{Virgil in Campania and Sicily.}

Either we must have recourse to the impossible hypothesis that the poet was writing of what he did not understand, or we must recall the fact, which is told us in his life by Suetonius, that he spent a great part of his time in Campania and Sicily, where in an autumn walk by the sea he might have seen what he here refers to. The multitude of migrants from France, Holland, and England take a south-easterly course in their autumn migration, and alight on any resting-place they can find,-- ships, islands, or wider sea-coasts like those of South Italy and Sicily. Here Virgil, we may be fairly sure, had scen them, and the longing of their hearts had entered into his, and borne fruit in a noble simile that is his, and not another's. Their journey, when he saw them, was not ended; like the pale and longing ghosts, they had yet another sea to cross, before they could find a winter's home in the secure sunshine of the south. 


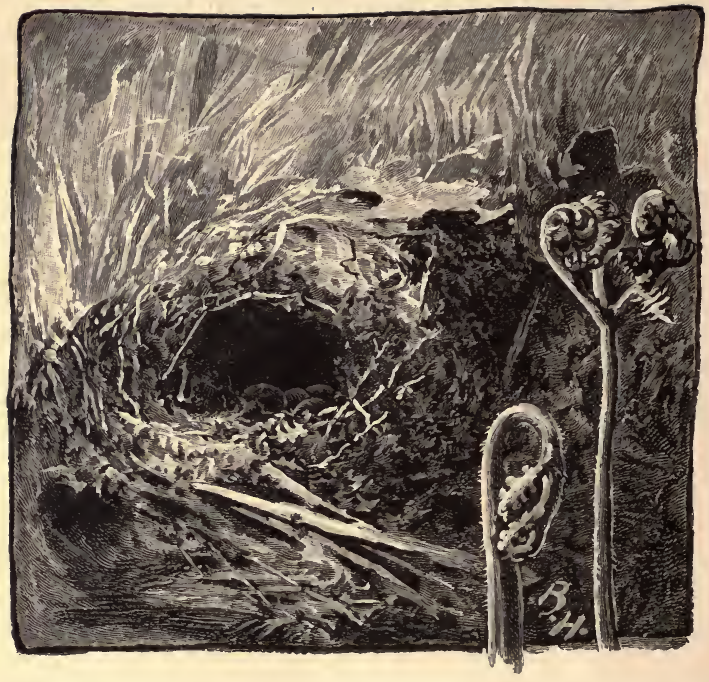

Willow-Warbler's nest,-See p. 26. 


\section{NOTES.}

\section{Note A. (p. I 4.)}

I ORIGINALLY intended to have added" a short chapter to the book upon the Wild Birds Act and the results obtainable from it; but as other chapters have grown to greater length than I expected, I confine myself to giving in this note, for the convenience of those who are kindly disposed towards the birds, the substance of the Act of 1880 , with a few words of explanation. Those who wish for more complete information should send for "The Wild Birds Protection Acts r 880 and I88 r, with Expl natory Notes' (published by Horace Cox, The Field Office, 346 Strand, W.C., price is.).

The Act in question, which was the result of most careful consideration by experts outside is well as inside Parliament, and was seen through the House of Commons by L. L. Dillwyn, Esq., M.P., one of a family of naturalists, repealed the then existing Acts relating to Wild Birds, which had been passed in the previous years without sufficient care for all interests. Its main provisions were as follows-

I. To protect all zuild birds of every description from being caught or killed between the rst of March and the rst of August.

2. To except from the above plain rule birds caught or killed by the owner or occupier of land on his ouen land, or by some person authorized by him.

3. To affix as penalties for offences against the above, for first offence, reprimand and discharge on payment of costs; for subsequent offences, a fine not exceeding five shillings. 
4. To schedule a number of birds which may not be caught or killed even on his own land, by owner or occupier, during the close time, and for the catching or killing of which the penalty is a sum not exceeding one found. These are chiefly rare birds, and a certain number of sea-birds; but among them are Cuckoo, Curlew, Dotterel, Fern-owl or Goat-sucker, Goldfinch, Kingfisher, Lark, Nightingale, Plover, Sandpiper, and Woodpecker.

It will be observed that this Act only protects the living bird of all ages, but not the eggs : so that bird-nesting may still go on with impunity. But the framers of the Act had very good reasons for omitting this, wanton cruelty as it often is; for as the offenders are usually of tender age, they must bc appealed to rather by education and moral suasion than by the terrors of the law. It lies with the clergyman and the schoolmaster to see that gross cruelty meets with its proper punishment - cruelty such as that which once occurred in my village, where some boys stopped up with clay the hole of a tree in which a Tit had laid her eggs, because it was too small to allow the entrance of the thieving hands.

The worst kind of bird-nesting is carried on by boys after they leave the village schoo', when they make this the employment of idle Sundays and holidays. The best remedy for this, and other habits that are worse, is to find other and rational cmployment for them. Reading-rooms, games, music, etc., I may remark, are usually out of their reach on Sundays, when most of the mischief is done. 


\section{Note B. On the Songs of Birds. (pp. 48 and I49.)}

As I have some musical knowledge, and have given some attention to the music of birds' songs, it may be worth while to add one or two remarks on a subject which is as difficult as it is pleasing. I need hardly say that birds do not sing in our musical scale. Attempts to represent their song by our notation, as is done, for example, in Mr. Harting's Birds of Middlesex, are almost always misleading. Birds are guided in their song by no regular succession of intervals ; in other words, they use no scale at all. Their music is of a totally different kind to ours. Listen to a Robin in full song; he, like most other birds, hardly ever dwells for a moment on a single note, but modifies it by s'ightly raising or lowering the pitch, and slides insensibly into another note, which is perhaps instantly forsaken for a subdued chuckle or trill. The same quality of song may also be well observed in the Black-cap and in the Willow Warbler: the song of the latter descends in an almost imperceptible manner through fractions of a tone, as I have already observed on page 48 . Strange as it may seem, the songs of birds may perhaps be more justly compared with the human voice when speaking, than with a musical instrument, or with the human voice when singing; and we can no more represent a bird's song in musical notation, than the inflections of Mr. Gladstone's voice when delivering one of his great speeches. The human voice when speaking is musically much freer than when singing; it is not tied down to tones and semitones.

If we remember that there are in our scale only twelve notes to the octave, and that between each of these an infinite number of sounds are possible, we shall get an idea of the endless variety which is open to the birds, and also, but in a less degree, to the human speaking voice. 
Some birds, however, occasionally touch notes of our scale, and sometimes, though rarely, two in succession. The Cuckoo, as has often been noticed, sings a major or a minor third when it first arrives; not that the interval is always exact. The Thrush may now and then repeat two or three notes many times over, which almost, if not quite, answer to notes in our scale, usually from $\mathrm{C}$ to $\mathrm{F}$ of our treble scale. The Nightingale's crescendo is a good instance of a single definite note; the song of the Chiff-chaff is perfectly plain and unvaried, but its two notes have never corresponded, when I have tested them, to an interval of our scale. Mr. A. H. Macpherson writes to me (Aug. 1886) that he has heard on the Brünig Pass, in Switzerland, three Chiff-chaffs singing at once, all in a different pitch. No. I was about a semitone above No. 2 ; No. 2 about a quarter of a tone above No. 3 : the interval being the same in all cases. As my correspondent is a violin-player as well as an ornithologist, his observation may be taken as accurate. The Yellow-hammer's curious song, which I examined carefully, may certainly be given in musical notation as keeping to a single note (often $\mathrm{C}$ or $\mathrm{C}$ sharp), but the concluding note of the song it is almost impossible to represent, for the pitch of the original note is raised or lowered by an interval varying from a minor third to less than a semitone. It is to be noted that in this species different individuals (according to my observation) have different modifications of the song; the Yellow-hammers in South Dorset (1886) struck me as singing in a different manner from our Kingham birds, though it would be almost impossible to describe the difference. I think I have noticed the same in the case of the Chaffinch. I have a note, made while travelling in Belgium, to the effect that the Chaffinches there did not seem to sing precisely the same song as ours in England. On the other hand, some observations which I made last year on the Chiff-chaff's two notes in different localities led me to believe that the various birds 
were all singing at about the same pitch and in much the same manner.

There are many other interesting points connected with birds' songs, e.g. the mechanism of the music; the song as a language; the entire absence of song in many birds, some of which, as the Crow, are among the most highly developed and intelligent ; and the causes which operate in inducing song. It would be well if some well-qualified naturalist would investigate some of these points with greater attention than they have yet received. It would be hardly possible to find a subject of greater interest to the public, as well as to the savant.

\section{Note C. Fables of the Kingfisher. (p. 242.)}

It may be worth while to suggest a possible explanation of the origin of the two curious and beautiful fables about this bird mentioned by Aristotle and Pliny, and current in antiquity. The first of these was, that for seven days before and seven days after the shortest winter day, the sea remained calm; during the first seven (says Aristotle) the bird builds her nest, and in the latter seven occupies herself with eggs and young. The second myth concerned the nest itself: "it is in shape like a cucumber, and larger than the largest sponge; the mouth is small-so small that the sea, as it rises, does not get inside it. It has, however, a great variety of holes, like a sponge, and appears to be made of the bones of a fish!" This last particular is curious, as we know it to be true of the Kingfisher's nest; and it has led Prof. Sundevall to believe that Aristotle must have received some authentic report of the real nest, and have mixed it up with the mythical account. But his whole account shows plainly that he imagined the nest to be built on the rocks by the seashore, and perhaps even within reach of the waves. 
Both these fables may, I think, have been built up on a slender basis of fact - the only fact which the Greeks seem to have known about the bird. Aristotle (Hist. Anim. v. 8. 4) tells us that the $a \lambda \kappa v^{\prime} \omega \nu$ was very seldom seen. "It is the rarest of all birds, for it is only seen at the setting of the Pleiades (about Nov. 9) and at the winter solstice ; and it appears at seaports flying as much as round a ship, and then vanishing away.' Whether the bird is still seen in Greecê only in late autumn and winter I cannot say; but Mr. Seebohm tells us (Brit. Birds, ii. 345) that in Eastern Europe it is compelled by the cold to migrate, some finding their way to Egypt, and therefore necessarily crossing the Ægean, or passing over Greece or the western coast of Asia Minor. I think it is a fair guess that those known to Aristotle were on their way from Thrace and Scythia to a warmer climate; and this hypothesis would explain not only their short stay, but their connection with the sea and harbours, and their mysterious character. Even supposing that a few haunted the Greek rivers at other times of the year, they would not be often seen there by a people not given either to sporting or to exploring out-of-the-way places; the one fact which would impress itself on the unscientific mind would be the sudden apparition in winter, and especially in mid-winter, of this little blue-green spirit about the harbours, and its as rapid disappearance.

If this be so, I think we have not far to seek for the origin of the two fables. Nothing being known of its nesting, it was assumed that it nested at or about the time when it appeared; and the not unfrequent calm and fine weather of mid-December would confirm the fancy, and give it a new mythical colouring. (The matter-of-fact philosopher does not of course allow that these fine days always occurred in his own experience; they are not always met, he says (v. 8. 3), in this country at the time of the solstice, "but they always occur in the Sicilian Sea.") When this fable of the nesting-time had once established itself, 
it would be not very difficult to find a nest among the curiosities of the sea. So the little blue bird came to suffer " a sea-change, into something rich and strange," through the careless fancy of the imaginative Greek.

\section{Note D. Redpolls in the Alps. (p. I95.)}

On page 49 of the first edition of this book there was a paragraph which described the shooting by Anderegg of a Lesser Redpoll (Linota rufescens) on the Engstlen Alp. The date was June $3 \circ$ (1884), and I had little doubt that the bird (which was a female) was one of a pair which had been breeding there. And this idea was confirmed by the discovery of a nest in the same place by Anderegg in May of the present year (1886), which Mr. Scott Wilson, who was with him at the time, considered to belong to the Lesser Redpoll.

The form, however, of the Redpoll which is usually found in the Alps is that which is usually called 'Mealy' (Linota linaria); this has been reported by Mr. Seebohm as pretty frequent in the Engadine, and by Prof. Newton, on the authority of Colonel Ward, as having been abuidant in Canton Vaud in the winter of $1874-5$. All the Redpolls I saw last September were, to judge from size and colouring, of this form: so also were all that I have seen in Swiss museums marked as having been shot in the Alps. Believing therefore, on these grounds, and in deference to the arguments of the Rev. H. A. Macpherson, that both Mr. Scott Wilson and myself had made a mistake, I struck out the paragraph in question from my second edition.

Since doing so, however, I have paid a visit to Cambridge, where Prof. Newton pointed out to me a passage in Prof. Giglioli's recently published catalogue of Italian birds bearing 
on the point. He writes without hesitation of Linota rufescens as occasionally breeding in the Italian Alps. This induces me to add this note to the present edition; for if it could be distinctly proved that $L$. rufescens is $f$ und breeding in the Alpine region, new light would be thrown, not only on the curious geographical distribution of this form, but on the abnormal character of the ornithology of the Alps. Prof. Giglioli may be himself mistaken, and as Anderegg and I failed to skin our bird, we cannot produce it as evidence; but my notes made while examining it point dec.dedly to $L$. rufescens rather than L. linaria, the length, for example, appearing as only four inclies. 


\section{INDEX OF BIRDS MENTIONED IN THE VOLUME.}

\section{(The scientific names are those used in Dresser's List of European Birds.)}

Accentor, Alpine. Accentor collaris (Scop.), 95, 196.

Accentor, Hedge. Accentor modularis (Linn.), 95.

Aquatic Warbler. Acrocephalus aquaticus (Gmel.), 86.

Bittern. Botaurus stellaris (Linn.), 85.

Blackbird. Turdus merula (Limn.), 31, 60, 82, 88.

Blackcap. Sylvia atricapilla (Linn.), 51 foll., I I9, 164 .

Bonelli's Warbler. Phylloscopus Bonellii (Vieill.), 109.

Brambling. Frangilla montifringilla (Linn.), 172.

Bullfinch. Pyrrhula europaea (Vicill.), I2, 120.

Bunting, Corn. Emberiza miliaria (Linn.), I 39, 149.

Bunting, Reed. Emberiza schoeniclus (Linn.), 149.

Buzzard. Buteo vulgaris (Leach), 88.

Chiffchaff. Phylloscopus collybita (Vicill.), 38, 42 foll., 83, 92. Note 13 .

Chough, Alpine. Pyrrhocorax a'pinus (Koch.), 82, 93, 194, $23 j$.

Chough, Cornish. Pyrrhocorax graculus (Linn.), 93.

Citril Finch. Chrysomitris citrinella (Linu.), So, 97.
Corncrake. Crex pratensis (Bechst.), 65.

Crane. Grus coinmunis (Bechst.), 224 foll.

Creeper. Certhia familiaris (Linn.), 25, 190.

Crossbill. Loscia curvirostra (Linn.), r 83.

Crow. Corvus corone (Linn.), I 53, I87, 236, 237.

Cuckoo. Cuculus canorus (Linn.), 125-128.

Curlew. Numenius arquata (Linn.), 143.

Dipper. Cinclus aquaticus (Bechst.), 98.

Diver, Great northern. Colymbus glacialis (Linn.), 33 .

Eagle, Golden. Aquila chrysaetus (Linn.), 92.

Fieldfare. Turdus pilaris (Linn.), 35, 143.

Flycatcher, Pied. Muscicapa atricapilla (Linn.), 92, 133.

Flycatcher, Spotted. Muscicapa grisola (Linn.), 65, 130-134.

Garden-warbler. Sylvia salicari (Linn.), 5 I foll., 88.

Goldfincb. Carduelis elegans (Steph.), 138, 171, 242.

Grasshopper-warb.er. Locustella naevia (Bodd.), 154 foll. 
Greenfinch. Ligurinus chloris (Linn.), 65, 119.

Gull, Common. Larus canus (Linn.), I4I.

Hawfinch. Coccothraustes vulgaris (Pall.), 120.

Heron. Ardea cinerea (Linn.), 248.

Jackdaw. Corvus monedula (Linn.), 232.

Jay. Garrulus glandarius (Linn.), I 53.

Kestrel. Falco tinnunculus (Linn.), 32, I41, I 54.

Kingfisher. Alcedo ispida (Linn.), 13, 14, 187, 240, 241, 260.

Lark, Sky. Alauda arvensis (Limn.), 89.

Linnet. Linota cannabina (Linn.), I7 I, 172, 244.

Magpie. Pica rustica (Scop.), I 53.

Marsh Warbler. Acrocephalus palustris (Bechst.), 86.

Martin, Crag. Chelidon rupestris (Scop.), 91, 190.

Martin, House. Chelidon urbica (Linn.), 7, 190, 250.

Missel-thrush. Turdus viscivorus (Linn.), 98, I19.

Moorhen. Gallinula chloropus (Linn.), I3.

Nightingale. Daulias luscinia (Linn.), 66, 16r foll., 250.

Nightjar. Caprimulgus europaeus (Linn.), 134.

Nuthatch. Sitta caesia (Wolf), 25,128 .
Petrel, Stormy. Procellaria pelagica (Linn.), 33.

Pipit, Tree. Anthus trivialis (Linn.), 153.

Pipit, Water (or Alpine). Anthus spinoletta (Linn.), 94, 194, 196.

Plover, Common. Vanellus vulgaris (Bechst.), Ior, I43.

Ptarmigan. Lagopus mutuj (Leach), 82, 100.

Raven. Corvus corax (Linn.), 232, 234 .

Redpoll, Lesser. Linota rufescens (Vieill.), 21, 193, 262.

Redstart. Ruticilla phoenicurus (Iinn.), 62, 63, 88, I21.-

Redstart, Black. Ruticylla tithys (Scop.), 8o, 89, I 23 foll., I93.

Redwing. Turdus iliacus (Linn.), $30,142$.

Reed-warbler. Acrocephalu ; streperus (Vieill.), 41, 56, 57, 86.

Ring-dove. Columba palumbus (Linn.), 2 19 foll.

Ring-Ousel. Turdus torquatus (Linn.), 82, 98, 151.

Robin. Erithacus rubecula (Linn.), 9, 88, I19, 125-127, I40, 206.

Rock-dove. Columba livia (Bonnat), 219, 221.

Rook. Corvus frugilegus (Linn.), I34, I4I, I 42.

Sandpiper, Common. Totanus hypoleucus (Linn.), I37.

Sandpiper, Green. Totanus ochropus (Linn.), 136, 137.

Sedge-warbler. Ácrocephalus schoenobaenus (Linn.), 4I, 42, 57. 
Serin Finch. Serinus hortulanus (Koch.), 97.

Siskin. Chrysomitris spinus (Linni.), I 20.

Snipe, Jack. Gallinago gallinula (Linn.), 24.

Snow-Finch. Montifringilla nivalis (Linn.), 82, 100, 101.

Sparrow. Passer domesticus (Linn.), 64, 83.

Stonechat. Pratincola rubicola (Linn.), 147.

Swallow. Hirundo rustica (Linn.), 7, 90, 201, 250.

Swan. Cygnus musicus (Linn.), $237,238$.

Swift. Cypselus apus (Linn.), 65,90 .

Swift, Alpine. Cypselus melba (Linn.), 91.

Teal. Querquedula crecca (Linn.), $24 \mathrm{I}$.

Tern. Sterna fluviatilis (Naum.), 33.

Thrush, Song. Turdus musicus (Linn.), 30.

Tit, Blue. Parus caeruleus (Linn.), 29, 105, I5I.

Tit, Cole. Parus ater (Linn.), 52, 105.

Tit, Crested. Lophophanes cristatus (Linn.), I06, 184.

Tit, Great. Parus major (Linn.), 29, $105,151$.

Tit, Long-tailed. Acredula caudata (Linn.), 29, 105, I42.

Tit, Marsh. Parus palustris (Linn.), 29, 105.

Turtle-dove. Turtur communis (Selby), 133, 143, 219.
Wagtail, Gray. Motacilla melanope (Pall.), 17, 98, 186.

Wagtail, Pied. Motacisla lugubris (Temm.), 87, 148, 186.

Wagtail, White. Motacilla alba (Linn.), 87, 98.

Wagtail, Yellow. Motacilla raii $(B p), 64,$.138 .

Wall Creeper. Tichodroma muraria (Linn.), 82, IOI.

Wheatear. Saxicola oenanthe (Linn.), 98, 172, 204.

Whinchat. Pratincola rubetra (Linn.), 88, 145, 146.

Whitethroat. Sylvia rufa (Bodd.), 4I, 54 foll.

Whitethroat, Lesser. Sylvia curruca (Linn.), 40, 53 foll.

Willow-warbler. Phylloscopus trochilus (Linn.), 40-42, 47, 88.

Wood-pecker, Great Black. Dryocopus martius (Linn.), $104,184,185$.

Wood-pecker, Green. Gecinus Viridis (Linn.), 26, 165.

Wood-pecker, L.esser-Spotted. Dendrocopus minor (Linn.), 26, 166 .

Wood-pecker, Greater-Spotted. Dendrocopus major (Linn.), $18 \mathrm{I}$.

Wood-pecker, Three-toed. Picoides tridactylus (Linn.), 104, $19 \mathrm{I}$.

Wryneck. Yunx torquilla (Linn.), 167.

Yellow-hammer. Emberiza citrinella (Linn.), 88. 
Richard Clay and Sons, limited, LONDON AND BUNGAY. 


\title{
MESSRS. MACMILLAN \& CO.'S PUBLICATIONS.
}

\author{
BY THE SAME AUTHOR.
}

\section{TALES OF THE BIRDS. With Illustrations by BRYAN HOOK. New and Cheaper Edition, with an Additional Tale. Crown 8vo, 3s. 6d.}

Contents:- "A Winter's Tale"- "Out of Tune"-"A Jubilee Sparrow"- "The Falcon's Nest"- "A Debate in an Orchard "- "A Trafedy in Rook-life"- "A Question beginning with "Why" - "The Lighthouse"-and "The Owls' Revenge," which was not included in the first edition.

SATURDAY REVIEIV:- "It is one of the most delightful books about birds ever written. All the stories are good. . . He knows all about their social habits anl their solitary phases of life from close and constant observation, and makes the most profitable use of lis study as ornithologist by the prettiest alliance of his seience with the fancy and humour of an excellent story teller. . . The book finds sympathetic illustration in Mr. Bryan llook's clever drawing ."

GLOBE:- "Mr. Fow'er's book will be especially appreciated by young readers. He displays hoth a knowledgo and love of nature and of the animal ereation, and the tales have the merit moreover of conveying in an unostentatious way the best of morals. The illustrations by Mr. Bryau Hook are admirably drawn and engraved."

GLARDIAN :- "Mr. Fowler has produced a eharming book, which unne are too old and few too young to appreciate. He possesses the rare art of telling a story simply and unaffectedly; he is pathetic without laborious effort; he excels in suggesting the effect which he desires to prodnce. A quiet vein of humour runs through many of the stories, and many slirewd strokes of kindly satire are given under the guise of his pleasant fal,les. . . Apart from the interest of the stories themselves, the pages are brinful of minute observation of the ways and habits of bird life. The Tales of the Birds would be an admirable present to any child, and if the gro:wn-up donor read it first, the present would, in a peculiar degree, confer the doulle blessing which proverbially belongs to a gift."

LITERARY WORLD:- "Those who want to choose a book for holiday reading should ask for Tales of the Birds. . W W might continue to deseribe one pretty parable after another. 'The Jubiloe Sparrow' is full of humour, and 'Out of Tune' carries a pathetic yet practical moral of inward and outward harmony. Several others are equally charming, but we must forbear more than a ccucluding word of hearty commendation. This is the sort of book to read."

ST. JAMES"S GAZETTE:- "We searcely know which we like best of these eharming stories. . Every piece gives us some further glimpso into the ways of birds and makes us feel fonder of them." 


\title{
MESSRS. MACMILLAN \& CO.'S PUBLICATIONS.
}

\author{
BY DR. ATKINSON.
}

Fourth Thousand. Extra Crown 8vo. 8s. 6d. net.

\section{FORTY YEARS IN A MOORLAND \\ PARISH. Reminiscences and Researches in Danby-in. Cleveland. By the Rev. J. C. Atrinson, D.C.L., Incum- bent of the Parish and Canon of York; Author of "A History of Cleveland," "A Glossary of the Cleveland Dialect."}

NATION:-"Is nothing less than an almost exhaustive monograph upon a typical English parish. Nearly every feature of its life and inanimate nature is described with the sure and interesting touch of a trained and loving observer. . . The book is of peculiar value to the student of folk-lore and of English history (cspecially of the earlicr period); while the philologist will find here and there many quaint phrases to be added to the author's well-known Glossary of the Cleveland Dialect. . . Mr. Atkinson has left no side of his parish uninvestigated."

FIELD :- "We have rarely come across a nore delightful and instructive volume of local parochial history. Whether we regard it from its antiquarian, geological, historical, or descriptive point of view, we can accord it nothing but praise. It has not a dull page in it. The manners and customs of the people and their traditions when the author first took possession of his parish are delightful reading. . . It is a model of what a local county history should be."

BRITISH WEEKLY:- "I have not found a more interesting hook this year than Dr. Atkinson's; his careful, faithful chapters on Folk-lore, Antiquities, Manners, and Customs, and the rest, would keep you up far into the night, and the personality they reveal-shy, learned, kind, and wise-is greatly attractive."

PALL MALL GAZETTE :- " This is an admirable piece of work. Dr. Atkinson has come to his task thoroughly well equipped. . He knows every corner of 'Danby-in-Cleveland '-for that is the name of the parish which is happy enough to own him for its Rector,-and not only every corner, but the ways and thoughts of its people. Of course there are many parsons, one is glad to think, who have done as much; but then our author is a man of the study as well as of the field. He has studied history in its initial sources, in records, registers, chartul:rries, muniments, all the lore which is so invaluable as material for history, because it was never intended for that purpose. Thus he illustrates and interprets the present by the past. What is, is explained for him by what has been, as it never can be to the unlearned. What has been, is vivified by what is, in a way that is impossible to the mere student. The active clergyman is a valuable person; valuable also is the learned antiquarian. Combine the two, and you have indeed temperamentum egregium. . . Certainly this is one of the best books of the year." 


\section{MESSRS. MACMILLAN \& CO.'S PUBLICATIONS.}

Edited by Rev. J. G. WOOD.

WANDERINGS IN SOU'TH AMERICA, the North-West of the Urited States and the Antilles. By Charles Watrrton. Lditel by Rev. J. G. Woop. With 100 IIllustrations. C'rown 8vo, $6 s$.

People's Edition. With 100 Illustrations. Mediun 4to. 6d.

By CHARLES KINGSLEY.

GLAUCUS; or, The Wonders of the Sea Shole. By Charles KingsLey. With Coloured Illustrations, extra cloth, gilt edges. Presentation Edition, Crown 8vo, 7s, 6d.

Cheaper Edition. Crown 8vo, 3s. 6d.

MADAM HOW AND LADY WHY; or, First Lessons in Earth-Lore for Children. By the Same. Crown 8vo, 3s. 6d.

PROSE IDYLLS. By the Same. Crown 8vo, 3s. $6 d$.

By SIR J. E. EDWARDS-MOSS.

A SEASUN IN SUTHERLAND. By Sir J. E. EdwardsMoss. Crown 8vo, 1s. 6d.

\section{By GRANT ALLEN.}

on the Colours of Flowlers. By Grant Allen. Illustrated. Crown $8 v 0,3 s .6 d$.

\section{BY Dr. A. R. WALLACE.}

THE MALAY ARCHIPELAGO : The Land of the Orang Utang and the Bird of Paradise. By A. R. WALLACE, LL. D. Maps and Illustrations. Tenth Edition. Crown 8vo, 6s.

CONTRIBUTIONS TO THE THEORY OF NATURAL SELECTION ; and Topical Nature and Other Kssays. By the Same. New Edition. Cruwn 8vo, 68 .

ISLAND LIFE. By the Same. With Illustrations and Maps. Crown 8vo, $6 s$.

[Shortly.

DARIINISM. An Exposition of the Theory of Natural

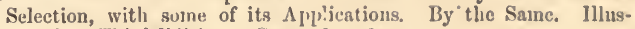
trated. Thirl Elition. Crown 8vo, 98. 


\title{
MESSRS. MACMILLAN \& CO.'S PUbLICATIONS.
}

\author{
By SIR SAMUEL BAKER, F.R.S.
}

WILD BEASTS AND THEIR WAYS. Reminiscences of Europe, Asia, Africa, and America. By the Same. Illustrated. Extra crown 8vo, 12s. $6 d$.

EDITED BY FRANK BUCKLAND.

NATURAL HISTORY AND ANTIQUITIES OF SEI BORNE. By Gildert Wiltre. Edited by Frank Buckland. With a Chapter on Antiquities by Lord Selborne. Crown 8vo, 6s.

BY H. A. BRIGHT.

A YEAR IN A LANCASHIRE GARDEN. By H. A. Bright. New Elition. Crown 8vo, 3s. 6d.

THE ENGLISH FLOWER GARDEN. By the Same. Crown $8 \mathrm{vo}, 3 s .6 d$.

\section{By MISS BALCH.}

GLIMPSES OF OLD ENGLISH HOMES. By Elizabeth BALCH. Illustrated. Globe 4to, $14 s$.

Bx SIR JOHN LUBBOCK, F.R.S.

THE ORIGIN AND METAMORPHOSES OF INSECTS. With Illustrations. By Sir JoHN LubBock, Bart. Crown 8vo, 3s. $6 d$.

ON BRITISH WILD FLOWERS CONSIDERED IN THEIR RELATION TO INSECTS. By the Same. With Illustrations. Crown 8vo, 4s. 6d.

FLOWERS, FRUITS, AND LEAVES. With Illustrations. By the Same. Crown 8vo, 4s. $6 d$.

BY SIR ARCHIBALD GEIKIE, F.R.S.

OUTLINES OF FIELD GEOLOGY. By the Same. With numerous Illustrations. New and Revised Edition. Crown 8vo, $3 s, 6 d$.

BY REV. HUGH MACMILLAN.

HOLIDAYS ON HIGH LANDS; or, Rambles and Incidents in Search of Alpine Plants. By Rev. Hugh Macmiluan. Second Edition. Globe 8ro, 63 .

By J. A. BRIDGES.

IDYLlS OF A LOST Village. By J. A. Bridges. Crown $8 \mathrm{vo}, 7 s .6 d$.

MACMILLAN AND CO., LONDON. 


\section{MACMILLAN AND CO.'S POPULAR NOVELS.}

Crown 8vo, Cloth, 3s. 6d. each.

BY J. H. SHORTHOUSE.

JOHN INGLESANT.

SIR PERCIVAL.

THE LITTLE SCHOOLMASTER MARK.

A TEACHER OF THE VIOLIN.

THE COUNTESS EVE.

BY MRS. CRAIK.

(The Author of "John Halifax, Gevtleman.")

OLIVE. With Illustrations by G. Bowers.

THE OGILVIES. With Illustrations by J. McL. RALSTON.

AGATHA'S HUSBAND. With Illustrations by WaLTER Crane.

HEAD OF THE FAMILY. With Illustrations by Walter Crane.

TWO MARRIAGES.

THE LAUREL BUSH.

MY MOTHER AND I. With Illustrations by J. McL. RALSTON.

MISS TOMMY : A Mediæval Romance. With Illustrations by FREDERICK NOLL PATON.

KING ARTHUR: Not a Love Story.

BY MRS. OLIPHANT.

A BELEAGUERED CITY.

JOYCE.

NEIGHBOURS ON THE GREEN.

KIRSTEEN.

HESTER.

HE THAT WILL NOT WHEN HE MAY.

MACMILLAN AND CO., LONDON. 


\title{
MACMILLAN'S THREE-AND-SIXPENNY SERIES.
}

\author{
Crown 8vo, Cloth, 3s. 6 d.
}

\section{BY VARIOUS AUTHORS.}

IOUISIANA; and THAT LASS O'LOWRIE'S. By FRANCES HIODGSON BURNETT.

LIVING OR DEAD? By Hugh CoNway.

A Family afFair. By Hugh Conway.

the CeERUleans. By Sir H. Cunningham.

THE HERIOTS. By Sir H. CunNingham.

WHEAT AND TARES. By Sir H. CunNiNGHAM.

THE WOODLANDERS. By THOMAS HARDY.

WESSEX TALES. By Thumas Hardy.

CRESSY. BY BRET HARTE.

THE HERITAGE OF DEDLOW MARSH. By Bret Harte

A LONDON LIFE. By HeNRY JAMES.

THE ASPERN PAPERS. By HENRY JAMES.

THE TRAGIC MUSE. By Henry James.

CASTLE DALY. By Ansie Keary.

YORK AND A LANCASTER ROSE. By ANNIE KEARY.

JANET'S HOME. By ANNIE KEARY.

OLDBURY. By ANNIK KEARY.

FAITHFUL AND UNFAITHFUL. By Margaret LeE.

REUBEN SACHS. BY AMY LEVY.

THE RING OF AMASIS. By Lord LyTTON.

MRS. LORIMER. By Lucas Malet.

AUNT RACHEL. By D. Christie Murray.

JOHN VAEE'S GUARDian. By D. Ciristie Murray.

SCHWARTZ. By D. Christie MurRay.

THE WEAKER VESSEL. By D. Christie MurRay.

HE FELL AMONG THIEVES. By D. Christie Murray and HeNRy Hekman.

MAROONED. By W. ClaRK RuSSELl.

MISS BRETHERTON. By MRS. HuMPHRY IVARD.

Uniform with the above.

STORM WARRIORS. By the Rev. JOHN GILMORE.

TALES OF OLD JAPAN. By A. B. MITFORD.

A YeAR WITH THE BIRDs. By W. WARde Fowler. Illustrated by BRYAN Hook.

TALES OF THE BIRDS. By the Same. Illustrated by BRYAN Hook.

LEAVES OF A LIFE. By Montagu Williams, Q.C.

LATER LEAVES. By Montagu Williams, Q.C.

TRUE TALES FOR MY GRANDSONS. By Sir S. IV. BAKER. TALES OF OLD TRAVEL. By HENRY KingSLey.

Other Volumes to follow. 




\section{S. TERP BRANCH, UNIVEIIOIIY (., CALIFORNIA, LIBRARY, LLOS ANGELES, CALK.}


